RADIOACTIVE WASTE ISOLATION IN SALT; GEOCHEMISTRY OF BRINE IN ROCK SALT IN TEMPERATURE GRADIENTS AND GAMMA-RADIATION FIELDS --

A SELECTIVE ANNOTATED BIBLIOGRAPHY

by

Amy B. Hull and Lynda B. Williams

Energy and Environmental Systems Division

Geoscience and Engineering Group

July 1985

work sponsored by

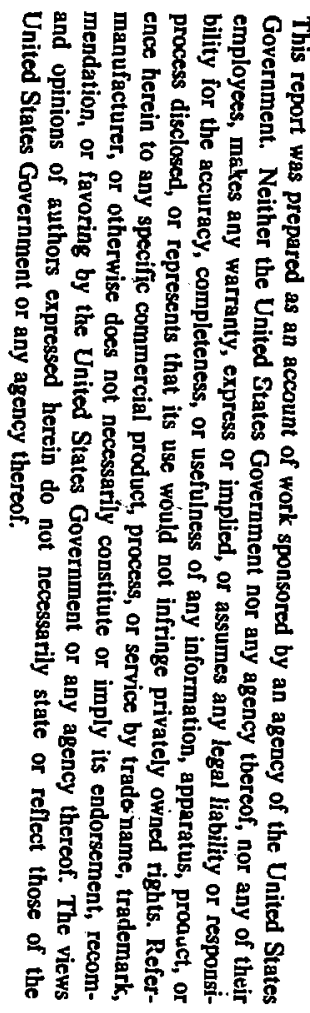

U. S. DEPARTMENT OF ENERGY

Office of Civilian Radioactive Waste Management

Salt Repository Project Office 


\section{FOREWORD}

Since late 1982, Argonne National Laboratory has been under contract to the U.S. Dep\&rtment of Energy (DOE) to conduct multidisciplinary peer reviews of program plans and reports covering research and development activities related to siting and constructing a mined repository in salt for permanent isolation of high-level radioactive waste. The documents are being submitted by Battelle Memorial Institute's Office of Nuclear Waste Isolation (ONWI) and other contractors to DOE's Salt Repository Project Office (SRPO) to satisfy milestones of the Salt Repository Project of the Civilian Radioactive Waste Management Program. Among the major programmatic documents to be generated by ONWI and its subcontractors are the site characterization plan, the surface-based test plan, and the in situ test plan.

This report provides an overview of the literature pertaining to the geochemistry of brines in rock salt in temperature gradients and gamma-radiation fields. The synopses of reports, journal articles, and papers based on conference presentations will assist readers in addressing such questions as: "What effects will gamma radiation have on brine chemistry and salt integrity?" and "Is brine migration a problem that needs to be dealt with?"

A Brine Migration Workshop, sponsored by DOE/SRPO, was held at the University of California, Berkeley, April 17-19, 1985. At the workshop, speakers stressed the need to objectively appraise the existing literature and to base future research on that appraisal. This report provides a ready resource for this effort. 


\section{PREVIOUSLY PUBLISHED REPORTS IN THE SERIES}

\section{"RADIOACTIVE WASTE ISOLATION IN SALT"}

ANL/EES-TM-242 Peer Review of the Office of Nuclear Waste Isolation's Geochemical Program Plan (Feb. 1984)

ANL/EES-TM-243 Peer Review of the Office of Nuclear Waste Isolation's Socioeconomic Program Plan (Feb. 1984) (revised July 1984)

ANL $/$ ES-TM-246 Peer Review of the Office of Nuclear Waste Isolation's Plans for Repository Performance Assessment (May 1984)

ANL/EES-TM-254 Peer Review of the Office of Nuclear Waste Isolation's Reports on Preferred Repository Sites within the Palo Duro Basin, Texas (June 1984)

ANL/EES-TM-256 Special Advisory Report on the Status of the Office of Nuclear Waste Isolation's Plans for Repository Performance Assessment (Oct. 1983)

ANL/EES-TM-258 Peer Review of the Office of Nuclear Waste Isolation's Plan to Decommission and Reclaim Exploratory Shafts and Related Facilities (July 1984)

ANL/EES-TM-259 Peer Review of the Office of Nuclear Waste Isolation's Final Report on the Organic Geochemistry of Deep Groundwaters from the Palo Duro Basin, Texas (Aug. 1984)

ANL/EES-TM-260 Peer Review of the Texas Bureau of Economic Geology's Report on the Petrographic, Stratigraphic, and Structural Evidence for Dissolution of Upper Permian Bedded Salt, Texas Panhandle (Aug. 1984)

ANL/EES-TM-261 Peer Review of the Office of Nuclear Waste Isolation's Report on Functional Design Criteria for a Repository for High-Level Radioactive Waste (Aug. 1984)

ANL/EES-TM-262 Peer Review of the D'Appolonia Report on Schematic Designs for Penetration Seals for a Repository in the Permian Basin, Texas (Sept. 1984)

ANL/EES-TM-263 Peer Review of the Office of Nuclear Waste Isolation's Report on Multifactor Life Testing of Waste Package Materials (Sept. 1984)

ANL/ES-147 Rationale and Methodology for Argonne-Conducted Reviews of Site Characterization Programs (July 1985) 


\section{CONTENTS}

ABSTRACT $\ldots \ldots \ldots \ldots \ldots \ldots \ldots \ldots \ldots \ldots \ldots \ldots \ldots \ldots \ldots \ldots \ldots \ldots \ldots \ldots \ldots \ldots \ldots \ldots \ldots$

1 INTRODUCTION $\ldots \ldots \ldots \ldots \ldots \ldots \ldots \ldots \ldots \ldots \ldots \ldots \ldots \ldots \ldots \ldots \ldots \ldots \ldots \ldots \ldots \ldots \ldots$

2 GEOLOGICAL AND GEOCHEMICAL BACKGROUND INFORMATION ........ 3

$3 \quad$ SALT FORMATIONS $\ldots \ldots \ldots \ldots \ldots \ldots \ldots \ldots \ldots \ldots \ldots \ldots \ldots \ldots \ldots \ldots \ldots \ldots \ldots \ldots$

3.1 Genesis $\ldots \ldots \ldots \ldots \ldots \ldots \ldots \ldots \ldots \ldots \ldots \ldots \ldots \ldots \ldots \ldots \ldots \ldots \ldots \ldots \ldots \ldots \ldots \ldots \ldots$

3.2 Evaporite Minerals $\ldots \ldots \ldots \ldots \ldots \ldots \ldots \ldots \ldots \ldots \ldots \ldots \ldots \ldots \ldots \ldots \ldots \ldots \ldots \ldots \ldots \ldots \ldots 6$

3.3 Fluid Sources $\ldots \ldots \ldots \ldots \ldots \ldots \ldots \ldots \ldots \ldots \ldots \ldots \ldots \ldots \ldots \ldots \ldots \ldots \ldots \ldots \ldots \ldots \ldots \ldots . . \ldots 9$

3.4 Brine Composition ................................. 10

4 THERMODYNAMICS OF ELECTROLYTES $\ldots \ldots \ldots \ldots \ldots \ldots \ldots \ldots \ldots \ldots \ldots \ldots$

4.1 Multicomponent Sait Solubility Studies $\ldots \ldots \ldots \ldots \ldots \ldots \ldots \ldots \ldots \ldots \ldots \ldots \ldots \ldots \ldots$

4.2 Geochemical Models ................................. 16

4.3 Miscellaneous ........................................ 18

5 CHEMICAL EFFECTS OF GAMMA RADIATION $\ldots \ldots \ldots \ldots \ldots \ldots \ldots \ldots \ldots \ldots \ldots \ldots$

6 BRINE MIGRATION STUDIES $\ldots \ldots \ldots \ldots \ldots \ldots \ldots \ldots \ldots \ldots \ldots \ldots \ldots \ldots \ldots \ldots \ldots$

7 BEHAVIOR OF RADIONUCLIDES $\ldots \ldots \ldots \ldots \ldots \ldots \ldots \ldots \ldots \ldots \ldots \ldots \ldots \ldots \ldots \ldots \ldots$

8 REPOSITORY-SPECIFIC ENVIRONMENTS $\ldots \ldots \ldots \ldots \ldots \ldots \ldots \ldots \ldots \ldots \ldots \ldots \ldots \ldots$

8.1 Generic Salt Repositories $\ldots \ldots \ldots \ldots \ldots \ldots \ldots \ldots \ldots \ldots \ldots \ldots \ldots \ldots \ldots \ldots \ldots \ldots \ldots 1$

8.2 Waste Isolation Pilot Plant Site $\ldots \ldots \ldots \ldots \ldots \ldots \ldots \ldots \ldots \ldots \ldots \ldots \ldots \ldots \ldots .5$ ?

FIRST AUTHOR INDEX $\ldots \ldots \ldots \ldots \ldots \ldots \ldots \ldots \ldots \ldots \ldots \ldots \ldots \ldots \ldots \ldots \ldots \ldots \ldots$

SUBJECT INDEX ..................................... 69

\section{TABLES}

1 Experimental Determination of Thermal Conductivities $\ldots \ldots \ldots \ldots \ldots \ldots \ldots \ldots$

2 Salt Parameters Controlled by Cap Rock Porosity .................... 10

3 Brine Formulations $\ldots \ldots \ldots \ldots \ldots \ldots \ldots \ldots \ldots \ldots \ldots \ldots \ldots \ldots \ldots \ldots \ldots \ldots \ldots \ldots \ldots$

4 Experimental and Anticipated Repository Conditions $\ldots \ldots \ldots \ldots \ldots \ldots \ldots \ldots$

5 Experimental Brine Migration Rates $\ldots \ldots \ldots \ldots \ldots \ldots \ldots \ldots \ldots \ldots \ldots \ldots \ldots \ldots \ldots \ldots . \ldots$

6 Threshold Temperature Gradients for No Migration ................... 42 


\section{TABLES (Cont'd)}

7 Adyantages and Disadvantages of Using Salt Formations for Nuclear Repositories ............................................ 56

\section{FIGURES}

1 Comparison of Calculated Activity Coefficients for $\mathrm{NaCl}$ and Smoothed Activity Coefficients for Alkali Chlorides

2 Concentration Profiles across a Fluid Inclusion in a Thermal Gradient

3 Temperature Profiles after Emplacement of CHLW in a Domal Salt Repository

4 Radiation Profiles af ter Emplacement of CHLW in a Domal Salt Repository 


\title{
RADIOACTIVE WASTE ISOLATION IN SALT: \\ GEOCHEMISTRY OF BRINE IN ROCK SALT IN TEMPERATURE \\ GRADIENTS AND GAMMA-RADIATION FIELDS - \\ A SELECTIVE ANNOTATED BIBLIOGRAPHY
}

by

Amy B. Hull and Lynda B. Williams

\begin{abstract}
Evaluation of the extensive research concerning brine geochemistry and transport is critically important to successful exploitation of a salt formation for isolating high-level radioactive waste. This annotated bibliography has been compiled from documents considered to provide classic background material on the interactions between brine ard rock salt, as well as the most important results from more recent research. Each summary elucidates the information or data most pertinent to situations encountered in siting, constructing, and operating a mined repository in salt for high-level radioactive waste. The research topics covered include the basic geology, depositional environment, mineralogy, and structure of evaporite and domal salts, as well as fluid inclusions, brine chemistry, thermal and gamma-radiation effects, radionuclide migration, and thermodynamic properties of salts and brines.
\end{abstract}

\section{INTRODUCTION}

In the last 10 years, research on brine geochemistry and transport has intensified as salt formations have come into consideration for isolation of high-level radioactive waste in mined repositcries. This annotated bibliography summarizes the results of experimental and theoretical research on the effects of temperature gradients and gamma-radiation fields on brine in rock salt. It includes documents considered to be classics in the field, as well as those reporting on more recent investigations.

The research topics covered include the basic geology, depositional en rironment, mineralogy, and structure of evaporite and domal salts, as well as fluid inclusions, brine chemistry, temperature and radiation effects, radionuclide migration, and thermodynamic properties of salts and brines. Each summary elucidates the information most pertinent to the geologic environment associated with candidate sites for a repository in salt for high-level radioactive waste. Tables are included of some of the most recently derived thermodynamic data, and equations are presented that model fluid flow in a repository brine system. The result is that such frequently used information is easily accessible. 
The authors made no attempt to critically assess the work summarized in this annotated bibliography. The intent was to compile summaries of a cross section of the relevant literature on this topic. The inclusion or omission of a specific article should not be interpreted as an endorsement or rejection. The bibliography is divided into sections based on major relevant topics. Publications that address several topics are not listed repetitively; first author and subject indexes are included to aid in locating particular publications. 


\section{GEOLOGICAL AND GEOCHEMICAL BACKGROUND INFORMATION}

Braitsch, O. (1971), Sait Deposits: Their Origin and Composition, Springer-Verlag, Berlin, 297 pp.

Using innumerable figures and tables and citing over 300 references, Braitsch reviews and extends the work of Van't Hoff, Boeke, Janecke, Autenrieth, D'Ans, Braune, and others on stable and metastable equilibria of salt minerals, physicochemical conditions affecting formation of evaporites, and investigations of the mineralogy of salt deposits. Although paleogeography, stratigraphy, and petrography are not discussed extensively, the coverage is comprehensive within the areas of geochemistry and mineralogy.

Brookins, D.G. (1984), Geochemical Aspects of Radioactive Waste Disposal, SpringerVerlag, New York, 347 pp.

The generic depositional environment and the physical and chemical parameters characterizing the resultant formations are clearly presented for various bedded and domal salt deposits in the United States. Not all of these deposits are suitable for isolation of commercial high-level waste (CHLW) because government guidelines for mined repositories in bedded salt state that the salt unit must be at least $76 \mathrm{~m}$ thick and must occur at a depth of $600 \mathrm{~m}$ or less. These requirements were instituted to ensure repository stability; at depths greater than $600 \mathrm{~m}$, repository openings will be destroyed by salt creep caused by lithostatic pressure. Temperature increases at this depth also have a pronounced effect on the rate of creep and the compressive strength of salt. The water content of fluid inclusions and brine pockets is briefly addressed. There is some concern that water traveling toward the heat source represented by the radioactive waste may be heated to the point of high energy release, resulting in rock fracture (decrepitation). However, Brookins believes that the temperatures needed to cause this fracturing are much higher $\left(250^{\circ} \mathrm{C}\right)$ than those expected at a repository $\left(100^{\circ} \mathrm{C}\right)$. Overall, a good general review is provided of the generic salt repository and the reasoning behind emplacement of radioactive waste in salt.

Another good general review is provided of average background radiation sources in the geologic environment and the health hazards and environmental effects associated with natural radiation. Brookins cites several studies on the effects of natural radiation from various rock types on populations living near such radioactive terranes. Generally, no harmful effects were detected in areas where background radiation is highest: Colorado, $105 \mathrm{mrem} / \mathrm{person} / \mathrm{yr}$, and South Dakota, $115 \mathrm{mrem} /$ person/yr. Brookins summarizes the chemistry of the various natural radionuclides and discusses sources, processes of concentration, mobility, and environmental effects of subsequent dosages. 
Kaufmann, D.W., ed. (1960), Sodium Chloride: The Production and Properties of Salt and Brine, American Chemical Society Monograph Series No. 145, Reinhold Publishing Corp., New York, 743 pp.

Probably the most comprehensive text on salt available anywhere, and a very valuable background source for any question that arises regarding salt, this classic must be included in a comprehensive list of salt studies. Over 1000 references direct the reader to further information. The author exhaustively discusses not only the geological aspects of salt (i.e., mineralogy, petrology, geologic environment, and location of major salt deposits), but also various aspects of salt mining, production, milling, and purification. Chapters are dedicated to types of salt, salt brine, and analytical methods for salt, including chemical parameters of salt media. The uses, handling, storage, and economic value of salt are among the concluding chapters of the book.

Lerman, A. (1979), Geochemical Processes, Wiley-Interscience, New York, 481 pp.

An extremely useful text and reference book emphasizing time-dependent plienomena in water and sediment environments, with extensive material in the form of detailed figures, tabulated data, and literature references, this book has become widely used by water-oriented geologists, chemists, limnologists, oceanoriented scientists, and environmental engineers.

The discussion of molecular and thermal diffusion is of ten cited by researchers examining the migration of brine derived from fluid inclusions. Thermal diffusion in solutions (the Soret effect) is presented very clearly. A table of Soret coefficients is given for some dissolved species in water, including salt, at concentrations ranging from $0.0005 \mathrm{M}$ (mol/L) to $4.04 \mathrm{M}$ and at $25^{\circ} \mathrm{C}, 31-34^{\circ} \mathrm{C}$, and $37^{\circ} \mathrm{C}$. Molecular diffusion soefficients for salt through media of varying porosity and gas diffusion coefficients are tabulated. Numerous examples further clarify the equations and information.

Sonnenfeld, P. (1984), Brines and Evaporites, Academic Press, Orlando, Fla., 624 pp.

This book provides an overview of brines and evaporites, discussing brine formation, primary precipitation of minerals, and postdepositional alterations. These topirs are all relevant to siting a nuclear repository in salt. The evaporitic environment and the major synsedimentary (paragenetic) structural features are spelled out in detail. Mineralogical data are tabulated for the evaporitic minerals. Transport of brines is also discussed. In the section on admixtures to precipitates, the following topics are covered: substitutions and accessory precipitates, behavior of clastics in a hypersaline brine, behavior of base metals, and alteration of organic matter to petroleum. 


\section{SALT FORMATIONS}

\subsection{GENESIS}

Eugster, H.P., and B.F. Jones (1379), Behavior of Major Solutes during Closed-Basin Brine Evolution, American Journal of Science, 279:609-631.

To examine the processes controlling brine evolution, Eugster and Jones used data from some of the better known hydrologically closed basins such as Magadi, Kenya; Lake Albert, Oregon; Great Salt Lake, Utah; Deep Springs Lake, California; Devils Lake, North Dakota; and Basque Lake, British Columbia. Chemical fractionation involving the eight or so most abundant initial solutes $\left(\mathrm{SiO}_{2}, \mathrm{Na}^{+}, \mathrm{K}^{+}, \mathrm{Ca}^{2+}, \mathrm{Mg}^{2+}, \mathrm{HCO}_{3}^{-}, \mathrm{Cl}^{-}, \mathrm{SO}_{4}{ }^{2-}\right.$ ) can be accounted for by a number of mechanisms, including (1) mineral precipitation of carbonates and silicate cements, (2) selective dissolution of efflorescent crusts and carbonate sediment coatings, (3) sorption on active surfaces in which $\mathrm{K}^{+}$is preferentially adsorbed while $\mathrm{Na}^{+}$remains dissolved, (4) degassing of $\mathrm{CO}_{2}$ from water, and (5) redox reactions in which sulfates are bacterially reduced. These mechanisms result from equilibration with the atmosphere, increase in temperature, decrease in solubility with salinity, or organic activities such as photosynthesis. On the other hand, $\mathrm{Na}^{+}$and $\mathrm{Cl}^{-}$behave as conservative elements (i.e., remaining in solution throughout the concentration process) and can be used to monitor the progress of evaporative concentration.

Fractionation processes depend strongly on circulation patterns. If paths are restricted largely to the surface, fractionation will occur through direct mineral precipitation, degassing, or oxidation. If subsurface circulation becomes important, then efflorescent crusts and soil coatings will be significant. In large basins, longer circulation paths provide a longer residence time for groundwater. Time is provided for adsorption and exchange reactions between waters and fine-grained sediments. The more anaerobic conditions facilitate bacterial reduction.

Hardie, L.A. (1984), Evaporites: Marine or Non-Marine?, American Journal of Science, 284:193-240.

Evaporites are divided into primary and secondary groups. Only primary autochthonous evuporites give information about the marine or nonmarine origin of the deposit. Secondary evaporites are too extensively altered, and their primary structures have been destroyed. Evaporites deposited in a marine depositional setting do not necessarily have to have been derived from seawater because hydrologic restriction in a sabkha environment could result in significant water input from a nonmarine source. 
Hardie cites several examples of modern nonmarine evaporites whose chemistry and mineralogy are similar to marine deposits to illustrate the common confusion between the two. He suggests criteria that could be used to distinguish marine from nonmarine autochthonous evaporites and details how to interpret these parameters. The sedimentological criteria include the kinds of fossils present and the nature of associated nonsaline facies. The mineralogical criteria include the kinds of primary and penecontemporaneously formed saline minerals and the association and vertical succession of such saline minerals, both on a stratumfor-stratum scale and overall-deposit scale. The chemical criteria include the trace element and isotope geochemistry and the fluid inclusion chemistry of the saline minerals.

Wilgus, C.K., and W.T. Holser (1984), Marine and Nonmarine Salts of Western Interior, United States, American Association of Petroleum Geologists Bulletin, 68:765-767.

In the western interior of the United States, the salts of the Delaware, Alliance, and Williston basins record a variety of salt basins, ranging from normal marine with varied brine concentrations to nonmarine and recycled, that represent times of complete isolation from marine influence. The Delaware Basin sample was taken at the Waste Isolation Pilot Plant (WIPP) site.

Within the Delaware Basin, the Salado and overlying Rustler Formations are part of the Ochoan Series of the uppermost Permian and contain high proportions of evaporites formed in a basin with marine inflow not far to the southwest. The Salado Formation comprises predominantly halite and potash facies. During the later Rustler deposition, a marine influence extended northwest of the evaporitic facies, as indicated by interbeds of dolomitized limestones containing marine facies. Both the Salado and Rustler salts were, on the basis of bromide content in the halite (50-100 ppm or more), precipitated from normal marine brines. Bromide concentrations in the Western Interior halites from the Williston, Alliance, and Delaware basins are compared.

\subsection{EVAPORITE MINERALS}

Cody, R.D., and A.B. Hull (1980), Experimental Growth of Primary Anhydrite at Low Temperatures and Water Salinities, Geology, 8:505-509.

Understanding the role of organic matter in the deposition of evaporite systems is important to understanding the observed precipitation and dissolution reactions of major evaporite minerals. In this experimental study, Cody and Hull propose that primary formation of anhydrite may occur in an evaporitic environment if gypsum nucleation is inhibited by the presence of certain macromolecular organic compounds. 
An evaporite sedimentary environment was simulated in the lab. Reactants for the system were 1 normal (N) $\mathrm{CaCl}_{2} \cdot 2 \mathrm{H}_{2} \mathrm{O}$ and $1 \mathrm{~N}\left(\mathrm{NH}_{4}\right)_{2} \mathrm{SO}_{4}$ with $5 \% \mathrm{NaCl}$ in solutions and pore fluids. Sodium bentonite was used as a base sediment. The temperature was held at $60^{\circ} \mathrm{C}$ while most of the standard organic crystallizationinhibitors were individually introduced. Under these conditions, only gypsum was nucleated. However, when a polyacrylic acid, polymaleic acid, or phosphate ester was introduced as organic crystallization modifiers, gypsum growth was inhibited and anhydrite crystals grew readily. The crystals were numerous and closely spaced, and formed rectangular laths typical of natural sedimentary anhydrite. Anhydrite may not only form as a replacement of gypsum in an evaporitic environment, but may also form by primary nucleation at temperatures and ionic concentrations typical of the waters of hot, arid regions, if certain types of organic substances are also present.

Hansen, F.D. (1984), Physical and Mechanical Variability of Natural Rock Salt, Proc. Second Conf. on the Mechanical Behavior of Salt, Trans Tech Publications, ClausthalZellerfeld, West Germany, in press, 17 pp.

The effect of chemical impurities in rock salt on creep deformation was evaluated for representative specimens from Palo Duro Basin, Avery Island, and Salina Basin. Procedures used in the experimental examination are carefully outlined, including sample preparation, optical petrography by point counting, etch-pit studies, and microprobe analyses. Both salts from the Palo Duro Basin averaged $94 \%$ halite, less than 1\% fluid inclusions, $2.7 \%$ anhydrite, $2.5 \%$ clays, and only a trace of other impurities. Bulk chemical analyses showed that Avery Island salt averaged 99.1\% halite, $0.6 \%$ anhydrite, and $0.2 \%$ insolubles (crystallites of dolomite). The Salina Basin salt, which was the most heterogeneous of the four salts examined, comprised more than $90 \%$ halite, with anhydrite being the prineipal impurity.

The results of constant stress triaxial compression tests were most influenced by impurity content at $25^{\circ} \mathrm{C}$. The influence on creep deformation of impurity content decreases as temperature increases. Impurities appear to be much more important at lower temperatures because the flow mechanism (glide of free dislocations) is easily impeded by impurities. However, impurities that can be seen easily with an optical microscope cannot be correlated on a one-to-one basis with mechanical variability: the arrangement of the impurities in the crystal lattice ray be as important as the quantity or species of the impurities.

At $25^{\circ} \mathrm{C}$, strain varied by $400 \%$; at $200^{\circ} \mathrm{C}$, the difference was $50 \%$. Compression experiments at $50^{\circ} \mathrm{C}, 75^{\circ} \mathrm{C}$, and $100^{\circ} \mathrm{C}$ indicated a gradual change from dislocation glide to dislocation climb. At $200^{\circ} \mathrm{C}$, the predominant mechanism of diffusion-controlled climb facilitates movement of dislocations past the impurities. The applied stresses examined included $5.0 \mathrm{MPa}, 7.5 \mathrm{MPa}, 10.0 \mathrm{MPa}$, and $15.0 \mathrm{MPa}$. At $15 \mathrm{MPa}(150 \mathrm{~atm})$ confining pressure, rock salt deforms primarily by intracrystalline processes. Under conditions of high stress and elevated temperature, samples may shorten up to $20 \%$ without void formation or 
cleavage fractures. High strain without fracture is enhanced at all temperatures by the inclusion of impurities such as calcium.

Sonnenfeld, P., and P.P. Hudec (1985), Origin of Clay Films in Rock Salt, Sedimentary Geology, 44:113-120.

Many of the bedded salt formations suitable for nuclear repository construction are characterized by thin but pervasive clay intercalations traditionally thought to represent "freshening" of the brine body (i.e., dilution by fresh or low-salinity water). However, there is geological evidence that the water column was not extensively diluted. For example, in the Permian evaporites of New Mexico, clay intercalations cover euhedral crystals of halite that would have been beveled or corroded by any freshening. Microstratifications that develop in hypersaline brines slow down any clays swept in by flash floods. These clays spread out along the interface with the concentrated brine before they flocculate and slowly sink to the bottom, while still containing significant quantities of brine. This brine remains trapped and the preserved pore spaces serve as a horizontal conduit, permitting later epigenetic brines from other sources to move through an otherwise nearly impermeable evaporite deposit. Although not suggested by the authors, this mechanism might account for the compositions of fluid inclusions sometimes being so widely dissimilar.

Van den Broek, W. (1982), Impurities in Rock-Salt: Consequences for the Temperature Increases at the Disposal of High-Level Nuclear Waste, thesis, Technische Hogeschool, Delft, Netheriands, National Technical Information Service, NTIS PB83-102087, 51 pp.

In a salt formation, impurities with low thermal conductivity or low specific heat can aggravate temperature increases surrounding the burial site of high-level radioactive wastes. The concentration of impurities can range from $1 \%$ to $10 \%$ by weight. In very pure rock salt, the most important impurities are anhydrite and clay.

Van den Broek emphasizes the twofold effect on the temperature field created by specific heat and thermal conductivity variations in different minerals. Extra temperature increases of about $3 \%$ for each $1 \%$ of impurities may occur where the specific heat of the impurity is much lower. However, sylvite is the only impurity that has a lower specific heat than halite. The thermal properties of dolomite, anhydrite, sylvite, and quartz resemble those of halite. For example, their thermal conductivities are all about $5 \mathrm{~W} / \mathrm{m} \cdot{ }^{\circ} \mathrm{C}$. Other mineral inpurities had even lower thermal conductivities at $60^{\circ} \mathrm{C}$ (see Table 1 ). 
TABLE 1 Experimental Determination of Thermal Conductivities

\begin{tabular}{|c|c|c|}
\hline $\begin{array}{c}\text { Evaporite } \\
\text { Mineral }\end{array}$ & $\begin{array}{l}\text { Chemical } \\
\text { Formula }\end{array}$ & $\begin{array}{c}\text { Ti : n.al } \\
\text { Conduc civity } \\
\left(\mathrm{w} / \mathrm{m} \cdot{ }^{\circ} \mathrm{C}\right)\end{array}$ \\
\hline $\begin{array}{l}\text { Kainite } \\
\text { Kieserite } \\
\text { Carnallite } \\
\text { Polyhalite }\end{array}$ & $\begin{array}{c}\mathrm{KMgClSO}_{4} \cdot 3 \mathrm{H}_{2} \mathrm{O} \\
\mathrm{MgSO}_{4} \cdot \mathrm{H}_{2} \mathrm{O} \\
\mathrm{KMgCl}_{3} \cdot 6 \mathrm{H}_{2} \mathrm{O} \\
\mathrm{K}_{2} \mathrm{Ca}_{2} \mathrm{Mg}\left(\mathrm{SO}_{4}\right)_{4} \cdot 2 \mathrm{H}_{2} \mathrm{O}\end{array}$ & $\begin{array}{l}0.9 \\
2 \\
0.8 \\
2\end{array}$ \\
\hline
\end{tabular}

Source: Van den Broek (1982).

\subsection{FLUID SOURCES}

Lindstrom Jensen, K.E. (1982), Dissolution Rate of Salt Domes on the Basis of interpretation of Measured Salinity Profiles, in Scientific Basis for Nuclear Waste Management V, W. Lutze, ed., Elsevier, New York, pp. 429-438.

Salinity profiles above a salt dome depend on the dissolution rate and on the transport and dispersion of saltwater in adjacent strata. A method is described to determine the rate of dissolution, groundwater velocity, and dispersivity in the overlying strata as a function of measured salinity profiles. In the example cited (Danish salt dome Mors located in the northern part of Jutland), interpretation of the measured salinity profiles suggests an average domal dissolution rate of $0.0004 \mathrm{~mm} / \mathrm{yr}$, with a pore water velocity of $0.3 \mathrm{~mm} / \mathrm{yr}$.

The basic approach is to determine a time-dependent analytical solution for the concentration of salt in the groundwater, $c(x, y, z, t)$ :

$$
\frac{\partial c}{\partial t}=D_{x} \frac{\partial^{2} c}{\partial x^{2}}+D_{y} \frac{\partial^{2} c}{\partial y^{2}}+D_{z} \frac{\partial^{2} c}{\partial z^{2}}-v \frac{\partial c}{\partial x}
$$

where $D_{x}, D_{y}, D_{z}\left(m^{2} / y r\right)$ are the dispersion coefficients, and $v$ is the groundwater velocity. The explicit solution of this equation is shown for (1) the concentration of salt in the groundwater above the dissolution area or downstream from the dissolution area; (2) the cissolution rate where the cap rock has varying thickness, porosity, and permeability; and (3) time-dependent variations of the salinity profile. As shown in Table 2, pore water velocity, rate of dissolution, and dispersivity are interdependent functions of cap rock porosity. 
TABLE 2 Salt Parameters Controlled by Cap Rock Po:osity

\begin{tabular}{llll}
\hline $\begin{array}{c}\text { Porosity, } \\
f_{\alpha}\end{array}$ & $\begin{array}{c}\text { Pore Water } \\
\text { Velocity, } \\
v(\mathrm{~m} / \mathrm{yr})\end{array}$ & $\begin{array}{c}\text { Rate of } \\
\text { Dissolution, } \\
\mathrm{v}_{\mathrm{d}}(\mathrm{m} / \mathrm{yr})\end{array}$ & $\begin{array}{c}\text { Dispersivity, } \\
\alpha(\mathrm{m})\end{array}$ \\
\hline 0.03 & 0.00207 & $2.1 \times 10^{-6}$ & 17.92 \\
0.05 & 0.00346 & $3.6 \times 10^{-6}$ & 22.77 \\
0.1 & 0.00691 & $7.2 \times 10^{-6}$ & 26.38 \\
\hline
\end{tabular}

Source: Lindstron Jensen (1982).

\subsection{BRINE COMPOSITION}

Isherwood, D.J. (1979), Fluid Inclusions in Salt - An Annotated Bibliography, Lawrence Livermore National Laboratory Report UCID-18102, 29 pp.

This annotated bibliography critiques 38 articles and papers written in Russian and English. Most of the abstracts were taken directly from Fluid Inclusion Research (E. Roedder, editor), the most comprehensive source of information on fluid inclusions available. In addition to the bibliography, there is a brief summary of the physical and chemical characteristics that, together with the temperature of the waste, will determine the chemical composition of the brine in cortact with the waste canister, the rate of fluid migration, and the interactions between the brine, canister, and waste.

Lerman, A. (1970), Chemical Equilibria and Evolution of Chloride Brine, Mineralogical Society of America Special Paper 3, pp. 291-306.

Geological and theoretical evidence is examined for the relative rates of brine formation occurring during three primary processes:

1. E saquation, in which water is being removed from solution.

2. Sediment-brine reactions, such as dissolution, precipitation, ion exchange, and biological activity, through which solutions react with the surrounding rocks.

3. Mixing of brines of different composition and concentration. 
Assuming that a temperature of $75^{\circ} \mathrm{C}$ is reasonable for many of the brines occurring at depths of $1500-2500 \mathrm{~m}$ below the surface, Lerman uses data on 94 subsurface brines (containing $5-290 \mathrm{~g} / \mathrm{L}$ total dissolved solids [TDS]) to show that $\mathrm{Ca}$ enrichment occurs at the expense of $\mathrm{Mg}$, which precipitates out in the brine. Then $\mathrm{CaSO}_{4}$ minerals precipitate leaving a chloride-rich brine. Simplified models of gypsum, anhydrite, and halite solubility in brines are used to calculate thie state of saturation of a brine at $75^{\circ} \mathrm{C}$. For different sets of limiting conditions, estimated times of $30-150 \times 10^{6}$ yr are required for the $\mathrm{NaCl}$ concentration in the subsurface brine to attain $90 \%$ saturation. The concentrations of the individual dissolved components must be explicitly considered because the solubility of halite depend : smatically on the concentration and nature of the other ionic solutes presel...

Melchior, D., D. Langmuir, P.S.Z. Rogers, and N. Hubbard (1985), The Thermodynamics and Geochemistry of $\mathrm{Ca}, \mathrm{Sr}, \mathrm{Ba}$, and Ra Sulfates in Some Deep Brines from the Palo Duro Basin, Texas, in Scientific Basis for Nuclear Waste Management VIII, C.M. Jantzen et al., eds., Materials Research Society, Pittsburgh, pp. 483-489.

The geochemistry of underlying deep basin aquifers is a key issue in assessing the possible far-field effects of a repository breach. The candidate salt horizons in the lower San Andres Formation of the Palo Duro Basin in Texas are underlain by the Wolfcamp Formation, which consists predominantly of calcite and dolomite, and a granite wash composed of coarse arkosic sands and gravels deposited in deltaic fans adjacent to uplifted areas.

The solubilities of anhydrite, gypsum, celestite, barite, and radium sulfate in brines from five horizons in the Wolfcamp Formation and granite wash facies were modeled using ion-interaction equations. Results from this modeling indicate that all five brines are saturated with respect to anhydrite and celestite, and three of the five are saturated with respect to barite. Saturation may result from hydrologic connection to adjacent overlying evaporite units or increased $\mathrm{Ca}, \mathrm{Sr}$, and $\mathrm{Ba}$ concentrations caused by their desorption from clays. All five brines are undersaturated with respect to halite by a factor of three or more.

Radium concentrations are controlled by solid solution in other sulfate minerals in these low $\mathrm{pH}$ (4.4-6.3), high Ca (0.18-0.52 molal (m), high ionic strength (2.89$4.76 \mathrm{~m}$ ) brines. Since the brines are saturated or near saturation with respect to anhydrite, celestite, and barite, migration of additional ${ }^{226} \mathrm{Ra}$ or ${ }^{90} \mathrm{Sr}$ that might escape from a repository will be retarded. Further, precipitation of these sulfates along with trace ${ }^{226} \mathrm{Ra}$ and ${ }^{90} \mathrm{Sr}$ would be favored at higher temperatures near a repository because solubilities tend to decrease with increasing temperature. 
Molecke, M.A. (1982), A Comparison of Brines Relevant to Nuclear Waste Experimentation, Sandia National Laboratories Report SAND 83-0516, 58 pp.

Molecke describes the ionic composition of 18 brines used in laboratory tests related to nuclear waste or obtained from field studies. Solution $\mathrm{pH}$ values are also reported, but they should be used cautiously because the $\mathrm{pH}$ electrode junction potentials may result in measured $\mathrm{pH}$ values in concentrated brines being as much as one pH unit too low. None of the brine recipes in Table 3 has been formulated to include radiolytic species. Brines from the PacificNorthwest-Laboratories/Sandia Waste Package Interactions Test indicate changes in brine compositions foreed by interactions of the brine at $250^{\circ} \mathrm{C}$ with all components of the high-level waste system -- glass waste form, metallic canister, overpack, backfill, and host rock salt.

Roedder, E. (1984), Fluid Inclusions, Reviews of Mineralogy, Vol. 12, Mineralogical Society of America, Washington, D.C., 644 pp.

Over 2000 publications are referenced in this comprehensive volume, which combines review analyses with detailed experimental guidelines. Roedder

TABLE 3 Brine Formulations

High NaCl Content

High Na-Mg-K-Cl Content

WIPP Brine B
ONWI Composite Permian Basin
Brine P
ONWI Equilibrated Permian P No. 2
Pacific Northwest Laboratories/
Sandia Waste Package Inter-
actions Test Brines (pretest,
intermediate, and posttest
brines)
WIPP-12 (flow and downhole
samples)
Energy Research and Development
Administration-6 Brine (flow
and downhole samples)

WIPP Brine A

Materials Characterization Center Brine

WIPP Fluid Inclusion Brines Nos. 1 and 2

Quinare Brine Q (for Asse and Gorleben rock salt sites, where the sampled halite is close to carnallite and thus higher in $\mathrm{K}^{+}$ and $\mathrm{Mg}^{2+}$ )

U.S. Geological Survey Bittern Brine NBT-6a

Saturated $\mathrm{NaCl}$ (at $20^{\circ} \mathrm{C}$ and $100^{\circ} \mathrm{C}$ )

Standard Seawater 
introduces readers to all types of inclusions trapped in materials from earth and space, and describes their application to the understanding of geologic processes.

Roedder, E. (1984), The Fluids in Salt, American Mineralogist, 69:413-439.

This paper summarizes the physical and chemical prof arties of fluid inclusions in both bedded and domal salt deposits. It also reviews current studies on the types of fluids present in salt and discusses the origins of the fluids and how the fluids contribute to understanding the geologic processes that have occurred during the evolution of a salt deposit. The studies presented are pertinent to construction of a safe nuclear waste repository and prediction of events that may affect a waste disposal site.

Fluid inclusions trapped during the original crystallization of a bedded salt are primary fluid inclusions. Primary salt crystals may grow as thin square tablets. The growth stages of these crystals are normally outlined by zones of fluid inclusions that show up in a chevronlike pattern when a vertical section is cut through the salt. This pattern and the far greater abundance of fluid inclusions in primary salts help to distinguish primary from secondary, or recrystallized, salt deposits.

Most of the water in salt domes occurs as hydrous minerals or intracrystalline and intercrystalline fluid inclusions. The general chemical characteristics determined from larger inclusions in salt show: (1) $\mathrm{pH}$ values from 3 to 6; (2) $\mathrm{Eh}$ values from $-10 \mathrm{mV}$ to $-130 \mathrm{mV}$; (3) high density chloride solutions $\left(\sim 1.3 \mathrm{~g} / \mathrm{cm}^{3}\right)$ of $\mathrm{Na}, \mathrm{K}, \mathrm{Ca}$, and $\mathrm{Mg}$, with the dominant ion varying greatly, even in adjacent inclusions; (4) low sulfate; (5) $\mathrm{Br}$ ranges from less than $80 \mathrm{ppm}$ to $5000 \mathrm{ppm}$.

Roedder, E., and R.L. Bassett (1981), Problems in Determination of the Water Content of Rock-Salt Samples and Its Significance in Nuclear-Waste Storage Siting, Geology, 9:525-530.

Many determinations of internal water in rock salt have been made using a wide variety $c$. . physical and chemical methods that do not give comparable results. In this review paper, published analyses are discussed and their legitimacy evaluated. Results are generally too low; reported experimental values are commonly an order of magnitude less than the actual water content. A table of the theoretical water content and range of laboratory decomposition temperatures for some hydrous minerals found in rock salt demonstrates the variability of published analyses.

A reasonably explicit and unambiguous sampling and analytical scheme is presented as a suggested protocol for other researchers in their efforts to inirease the number of valid total-water determinations. Procedures are suggested for clearly discriminating between the quantitative contributions from the three water types considered here: hydrous minerals, intergranular fluid, and 
intragranular fluid. The procedures are needed so that the evolution of water from salt surrounding buried radioactive wastes can be more clearly modeled as a function of time.

Stewart, D.B., and R.W. Potter, II (1979), Application of Physical Chemistry of Fluids in Rock Salt at Elevated Temperatures and Pressure to Repositories for Radioactive Waste, in Scientific Basis for Nuclear Waste Management I, Plenum Press, New York, pp. 297-311.

The compositions of natural brines are described, the limits on their compositions and physical properties uader repository conditions are postulated, and the nature and implications of freezing-point depression in polycomponent salt systems are discussed. Brines penetrated by drilling or mining operations in salt deposits are classified as bitterns and share the following characteristics:

1. Bitterns contain significant amounts of $\mathrm{Mg}, \mathrm{Ca}, \mathrm{K}, \mathrm{Br}$, and $\mathrm{SO}_{4}$, as well as $\mathrm{Na}$ and $\mathrm{Cl}$.

2. Total dissolved solids in these brines are 20-40 wt. \%).

3. Their $\mathrm{pF}^{*}$ values are on the low side, ranging from 4 to 6 at $20^{\circ} \mathrm{C}$. They become even more acidic at higher temperatures.

4. As temperatures increase and as more components are added, the fluid mass increases while the total weight of water stabilizes, thus making the brine more concentrated.

Stewart and Potter emphasize that failure scenarios must be modeled using the appropriate, although negative, properties of the bitterns in súdition to the more benign properties of water or simple $\mathrm{NaCl}-\mathrm{H}_{2} \mathrm{O}$ mixtures. Although experimental values have still not been determined for many relevant bulk thermochemical properties, pressure-volume-temperature-concentration properties can be approximated from arguments of state based on equations of the form:

$$
\alpha_{s}=\stackrel{i}{\Sigma} f_{i} \alpha_{i}
$$

where:

$$
\begin{aligned}
& \alpha_{s}=\text { desired property of the brine, } \\
& f_{i}=\text { mole fraction of the ith binary component, and } \\
& \alpha_{i}=\text { desired property of the binary component at the same concentration as } \\
& \text { that of the total brine. }
\end{aligned}
$$




\section{THERMODYNAMICS OF ELECTROLYTES}

\subsection{MULTICOMPONENT SALT SOLUBILTY STUDIES}

Conradt, R., H. Engelke, and A. Kaiser (1982), Investigations of the Solution Behavior of $\mathrm{NaCl}$ in the Quinary System $\mathrm{NaCl}-\mathrm{KCl}-\mathrm{MgCl}_{2}-\mathrm{MgSO}_{4}-\mathrm{H}_{2} \mathrm{O}$ at Different Temperatures, in Scientific Basis for Nuclear Waste Management V, W. Lutze, ed., Elsevier, New York, pp. 487-490.

The German quinary brine $\mathrm{Q}$ accounts for the additional uptake of $\mathrm{NaCl}$ at higher temperatures. Experimental results indicate that this saturated brine contains over four times more $\mathrm{NaCl}$ at $187^{\circ} \mathrm{C}$, the maximum temperature investigated, than at $55^{\circ} \mathrm{C}$. The aralytical method used started with invariant point $Q$ of quinary system $\mathrm{NaCl}-\mathrm{KCl}-\mathrm{MgCl}_{2}-\mathrm{MgSO}_{4}-\mathrm{H}_{2} \mathrm{O}$ at $55^{\circ} \mathrm{C}$. More salt was added, and the dissolution temperature was measured. A pressurized system was used so that the liquid contents would not boil. No other components were examined.

Harvie, C.E., H.P. Eugster, and J.H. Weare (1982), Mineral Equilibria in the SixComponent Seawater System, $\mathrm{Na}-\mathrm{K}-\mathrm{Mg}-\mathrm{Ca}-\mathrm{SO}_{4}-\mathrm{Cl}-\mathrm{H}_{2} \mathrm{O}$ at $25^{\circ} \mathrm{C}$ : II. Compositions of the Saturated Solutions, Geochemica et Cosmochimica Acta, 46:1603-1618.

The authors discuss a powerful theoretical tool suitable for predicting the solubilities of different components in a complex brine. The described ion interaction approach has both strong advantages and liabilities compared with the older and more widely used ion association model. Claims are made that predicted solubilities are within $10 \%$ of corresponding experimental values. This model can be used for elucidating evaporite deposition in a wide variety of environments from marine to continental. Natural briries of system $\mathrm{Na}-\mathrm{K}-\mathrm{Mg}-$ $\mathrm{Ca}-\mathrm{SO}_{4}-\mathrm{Cl}-\mathrm{H}_{2} \mathrm{O}$ occur in continental salt lakes and pans, coastal lagoons and sabkhas, interstitial fluids of marine and nonmarine evaporites, and subsurface brines of sedimentary basins and oil fields. Brine infiltration effects can be assigned from the invariant point compositions and the natural brine composition. The consequences of dissolving minerals in a particular brine and of mixing brines can be evaluated. Adaptations for high-temperature conditions are not mentioned.

Harvie, C.E., N. Moller, and J.H. Weare (1984), The Prediction of Mineral Solubilities in Natural Waters: The $\mathrm{Na}-\mathrm{K}-\mathrm{Mg}-\mathrm{Ca}-\mathrm{H}-\mathrm{Cl}-\mathrm{SO}_{4}-\mathrm{OH}-\mathrm{HCO}_{3}-\mathrm{CO}_{3}-\mathrm{CO}_{2}-\mathrm{H}_{2} \mathrm{O}$ System to High lonic Strengths at $25^{\circ} \mathrm{C}$, Geochemica et Cosmochimica Acta, 48:723-751.

Based on a Pitzer-type thermodynamic solubility model, an earlier model based on fewer components has been extended to a multicomponent system $\mathrm{Na}-\mathrm{K}-\mathrm{Mg}-$ $\mathrm{Ca}-\mathrm{H}-\mathrm{Cl}-\mathrm{SO}_{4}-\mathrm{OH}-\mathrm{HCO}_{3}-\mathrm{CO}_{3}-\mathrm{CO}_{2}-\mathrm{H}_{2} \mathrm{O}$ at $25^{\circ} \mathrm{C}$ and high concentrations (up to $20 \mathrm{M})$. The major extension thus includes the addition of the carbonate system 
and acid-base equilibria. Model calculations are compared to experimental data in numerous systems including seawater. When the predicted $\mathrm{NaCl}$-saturated Janecke projection for the $\mathrm{Na}-\mathrm{K}-\mathrm{Cl}-\mathrm{SO}_{4}-\mathrm{CO}_{3}-\mathrm{H}_{2} \mathrm{O}$ quinary system is compared to experimental data, agreement is within $10 \%$.

\begin{abstract}
Although many aqueous solution models exist that rely on ion pairing, they are generally accurate only in dilute solutions. On the other hand, the virial expansion model presented in this paper, which includes strongly bound ion complex species, describes the observed response of most multicomponent electrolyte solutions to high concentrat:ons with good predictability compared to experimental values. Approximations in calculating the $\mathrm{pH}$ are discussed and thermodynamic interpretations of $\mathrm{pH}$ are made. The model is parameterized using many of the available isopiestic, electromotive force, and solubility data available for many of the subsystems. Data in binary and ternary systems were fit to the solution model.
\end{abstract}

Potter, R.W., II, and M.A. Clynne (1978), Solubility of Highly Soluble Salts in Aqueous Media - Part 1, NaCl, $\mathrm{KCl}, \mathrm{CaCl}_{2}, \mathrm{Na}_{2} \mathrm{SO}_{4}$, and $\mathrm{K}_{2} \mathrm{SO}_{4}$ Solubilities to $100^{\circ} \mathrm{C}$, Journal of Research of the U.S. Geological Survey, 6(6):701-705.

A modified visual method for determining solubilities is reported in this paper, as are the results of measurements of the solubility in water of $\mathrm{NaCl}, \mathrm{KCl}, \mathrm{CaCl}_{2}$, $\mathrm{Na}_{2} \mathrm{SO}_{4}$, and $\mathrm{K}_{2} \mathrm{SO}_{4}$ at temperatures up to $100^{\circ} \mathrm{C}$. The experimental methods are described in detail, along with the statistical variation in the numbers. The results of this work are applicable to both geothermal systems and hydrothermal ore-deposition systems. The visual method uses slow dissolution of a given salt in a highly illuminated glass chamber. The temperature at which the last crystal dissolves is the equilibrium temperature. The advantages of this simple method are (1) easy assembly, (2) stirring to overcome density stratification, (3) rapidity, (4) ability to run the same system (salt + water) several times, (5) large sample size ( $20 \mathrm{~g}$ may be used to increase the precision of known bulk composition), and (6) high precision. The solubility data presented are possibly the most reliable data available.

\title{
4.2 GEOCHEMICAL MODELS
}

Jackson, D.D. (1984), PROTOCOL, A Numerical Simulator for the Dissolution of Inorganic Solids in Aqueous Solutions, Lawrence Livermore National Laboratory Report UCRL-91631 preprint, 71 pp.

PROTOCOL is a computer software package that simulates the dissolution of solid phases in aqueous solutions. Experimentally derived leaching rate functions are coupled with thermochemical equilibrium calculations and water flow rates. By this kinetic-equilibrium coupling, the kinetic dissolution behavior of chemical species in aqueous systems can be predicted. The code contains an equilibrium 
capability based on the geochemical code MINEQL, which facilitates calculating the activities at equilibrium of all species considered in the problem and models solution concentrations and precipitate formation.

Much flexibility is built into the code so that suitable rate expressions for the dissolution behavior of different species can be incorporated as developed. PROTOCOL can accommodate all three of the models commonly used for predicting and interpreting the dissolution of inorganic solids: mechanistic models whose rate expressions are associated with specific chemical and physical processes, thermodynamic stability models based on general-purpose rate expressions that are complex summations of both forward and reverse reactions, and phenomenological mathematical models whose rate constants for both forward and backward reactions are experimentally established. No generalpurpose leaching function of wide applicability is yet developed.

The model can handle a multicomponent system and account for change due to processes such as leaching from solids, precipitation, water flow, and aqueous complexation. The data base values are all determined at $25^{\circ} \mathrm{C}$; applicability at or extension to higher temperatures, pressures, or the presence of radiation is not discussed. Effects of $\mathrm{pH}$ variation can be explicitly modeled with this program.

Wolery, T.J., D.J. Isherwood, K.J. Jackson, J.M. Delany, and I. Puigdomenech (1984), EQ3/6: Status and Applications, Proc. Conf. on the Application of Geochemical Models tc High-Level Nuclear Waste Repository Assessment, G.K. Jacobs and S.K. Whatley, eds., Oak Ridge National Laboratory Report ORNL-TM-9585, pp. 54-66.

EQ3/6 is a set of related computer codes (EQ3NR and EQ6) and thermodynamic data files for use in geochemical modeling of aqueous systems. EQ3NR is a speciation-solubility code whose function is to compute a model of the state of an aqueous solution. EQ6 is a reaction-path code that calculates changes in aqueous systems as they proceed toward overall chemical equilibrium. Input may consist of analytical measurements and chemical assumptions. The output contains the distribution of aqueous species, their thermodynamic activities, saturation indices for various solids, and the electrical balance of the fluid.

This code has recently been extended to include the geochemical modeling of brines by extending the range of solute concentrations over which dependable equilibrium calculations can be made. Solutions with ionic strengths as high as about 6 can be modeled. Pitzer's equations are now incorporated to calculate the activity coefficients of aqueous species and the activity of water. Ion pairs, complexes, and undissociated acids and bases are included as explicit component species in the Pitzer model. Solubility limits of evaporite minerals in brines can be predicted at both $25^{\circ} \mathrm{C}$ and elevated temperatures. The modeling of laboratory experiments through $\mathrm{EQ} 3 / 6$ can effectively resolve differences between laboratory results and field observations. 


\subsection{MISCELLANEOUS}

Helgeson, H.C. (1969), Thermodynamics of Hydrothermal Systems at Elevated Temperatures and Pressures, American Journal of Science, 267:729-804.

The equations and methods used to predict the thermodynamic characteristics of electrolyte solutions at high temperatures (to somewhat above $300^{\circ} \mathrm{C}$ ) are summarized. These thermodynamic properties (e.g., entropy of dissociation, osmotic coefficients, activity coefficients, heat capacities, enthalpies, and equilibrium constants) are presented in tables and diagrams. The numerical information contained in the tables permits calculation of the solubilities of silicates, sulfides, sulfates, and oxides in multicomponent high-temperature solutions containing high concentrations of $\mathrm{NaCl}$. One very useful diagram for application to brine chemistry in rock salt in a nuclear repository setting is that of the stoichiometric individual ion activity coefficients for sulfate ion as a function of temperature at constant $\mathrm{pH}$ in $3 \mathrm{M} \mathrm{NaCl}$ solutions. Temperatures ranged from $25^{\circ} \mathrm{C}$ to $300^{\circ} \mathrm{C}$, and $\mathrm{pH}$ values ranged from 2 through 7. Helgeson emphasizes that, below $300^{\circ} \mathrm{C}$, the standard state adopted for the aqueous phase is a hypothetical model solution at $0.1 \mathrm{MP} \Omega$ pressure and any specified temperature. In this work, pressure was considered as a variable only above $300^{\circ} \mathrm{C}$.

Marshall, W.L., and R. Slusher (1966), Thermodynamics of Calcium Sulfate Dihydrate in Aqueous Sodium Chloride Solutions, 0-110 ${ }^{\circ}$, Journal of Physical Chemistry, 6:4015-4027.

Gypsum $\left(\mathrm{CaSO}_{4} \cdot 2 \mathrm{H}_{2} \mathrm{O}\right)$ solubility in aqueous $\mathrm{NaCl}$ solutions was extensively measured. At temperatures of $70-95^{\circ} \mathrm{C}$ and at high $\mathrm{NaCl}$ concentrations, a double salt of $\mathrm{CaSO}_{4}$ and $\mathrm{Na}_{2} \mathrm{SO}_{4}$, in addition to $\mathrm{CaSO}_{4} \cdot 2 \mathrm{H}_{2} \mathrm{O}$, saturated the solution phase. Values for the solubility product constants and the variation of the ion solubility product with the ionic strength and temperature are tabulated for the several temperatures from which the thermodynamic functions at zero and high ionic strengths are calculated. The variation of these functions with ionic strength and temperature, as well as values of Gibb's free energy $\left(\Delta G^{\circ}\right)$, enthalpy $\left(\Delta \mathrm{H}^{\circ}\right)$, entropy $\left(\Delta \mathrm{S}^{\circ}\right)$, and heat capacity $\left(\Delta \mathrm{C}_{\mathrm{p}}^{\circ}\right)$ derived from the obtained solubility product, are graphed. Interpretation of these results by means of the extended Debye-Hulckel expression indicates that $\mathrm{CaSO}_{4}$ can be considered completely dissociated to $\mathrm{Ca}^{2+}$ and $\mathrm{SO}_{4}{ }^{2-}$ in aqueous solutions. Variation in the ion solubility product up to high ionic strengths $(2 \mathrm{~m})$ and at temperatures from $0^{\circ} \mathrm{C}$ to $110^{\circ} \mathrm{C}$ can be described by only one parameter, which is commonly referred to as the "ion-size parameter," $\&$, in the extended Debye-Hllckel expression. This parameter \& has a constant value of $4.5 \AA$ over the entire range of temperatures. Because of a breakdown in the structure of water at high temperatures, there is probably a resultant increase in the simplicity of the behavior of aqueous solutions compared to their behavior at $25^{\circ} \mathrm{C}$. 
Melchior, D.C. (1984), The Application of Ion-Interaction Theory of Electrolytes to the Solubilities of Copper and of Some Alkuline-Earth Sulfates in Brines, Ph.D. dissertation, Colorado Sehool of Mines, Golden, Colo., 91 pp.

The research presented in this dissertation is timely because it can be applied to hazardous waste mobilities. Melchior's experimental efforts were directed toward proving that Pitzer's ion-interaction model can be used to determine trace ion solubilities in a brine and major ion solubilities at high temperatures.

To test the trace ion modeling capabilities of the ion-interaction equations, solubility experiments were performed on tenorite $(\mathrm{CuO})$ and brochantite $\left[\mathrm{Cu}_{4} \mathrm{SO}_{4}(\mathrm{OH})_{6}\right]$, both relatively insoluble $\mathrm{Cu}^{2+}$ minerals. The experiments were conducted in 0.009-4.1 $\mathrm{m} \mathrm{NaCl}, 0.015-0.9 \mathrm{~m} \mathrm{Na}_{2} \mathrm{SO}_{4}$, and 0.8-2.6 m mixed electrolyte solutions with a $\mathrm{pH}$ range of 5.8-6.5. Melchior found that tenorite can be modeled in $\mathrm{NaCl}$ solutions up to $4 \mathrm{~m}$ and mixed electrolyte solutions up to $3 \mathrm{~m}$, but that tenorite and brochantite in $\mathrm{Na}_{2} \mathrm{SO}_{4}$ solutions had equilibrated. The solubility product $\left(\mathrm{K}_{\mathrm{sp}}\right)$ of tenorite and brochantite at $25^{\circ} \mathrm{C}$ based on the model and experimental support is:

$$
\begin{aligned}
& \mathrm{CuO}+\mathrm{H}_{2} \mathrm{O}=\mathrm{Cu}^{2+}+2 \mathrm{OH}^{-} \quad\left(\log \mathrm{K}_{\mathrm{sp}}=-21.8 \pm 0.1\right) \\
& 4 \mathrm{CuO}+\mathrm{SO}_{4}{ }^{2-}+4 \mathrm{H}_{2} \mathrm{O}=\mathrm{Cu}_{4} \mathrm{SO}_{4}(\mathrm{OH})_{6}+2 \mathrm{OH}^{-} \quad\left(\log \mathrm{K}_{\mathrm{sp}}=-73.4 \pm 0.1\right)
\end{aligned}
$$

Although these values are greater than the solubilities reported earlier in the literature, Melchior believes that their experiments were affected by excessive particle size. Melchior concludes that the ion-interaction equations can be used to model free trace metal ion activities when the activities are controlled by the solubility of fairly insoluble minerals.

Melchior also used the ion-interaction equations to examine the solubilities of $\mathrm{Ca}, \mathrm{Sr}, \mathrm{Ba}$, and $\mathrm{Ra}$ sulfates in some deep brines from the Wolfeamp Formation and granite wash aquifers in the Palo Duro Basin in Texas. These solubilities directly affect the mobilities of ${ }^{90} \mathrm{Sr}$ and ${ }^{226} \mathrm{Ra}$. Melchior adjusted the model to account for elevated temperatures at depth. Pressure did not influence the equations.

The experiments showed that the ion-interaction equations accurately model waters with ionis strengths from $2.9 \mathrm{~m}$ to $4.6 \mathrm{~m}$ at temperatures up to $41^{\circ} \mathrm{C}$. Several waters from the Palo Duro Basin were saturated with respect to gypsum, anhydrite, celestite, and usually barite; however, none was saturated with respect to $\mathrm{RaSO}_{4}$.

Rogers, P.S.Z. (1981), Thermodynamics of Geothermal Fluids, Ph.D. dissertation, University of California, Berkeley, 243 pp.

This research was undertaken to support construction of a computer model to predict the behavior of complex brines at high temperatures and pressures. To 
do this, basic thermodynamic properties of salts were required. Rogers concentrated the investigation on $\mathrm{NaCl}$, the most common salt in brines and geothermal fluids. Three main steps were taken to achieve the goal of obtaining thermodynamic data at high temperatures and pressures. First, a fitting equation was developed for volumetric properties of $\mathrm{NaCl}$ solutions heated to $300^{\circ} \mathrm{C}$ and $100 \mathrm{MPa}$. Known values of the Debye-Hulekel slopes for the apparent molal volume were included in the fitting equations. Second, volumetric properties and densities of $\mathrm{NaCl}$ were measured experimentally at very high and very low temperatures. Density data for $\mathrm{NaCl}$ solutions at $2 \mathrm{MPa}$, necessary to complete the description of volumetric properties, were also determined. Finally, a flow microcalorimeter was designed to obtain heat capacity data at high temperatures and pressures. Heat capacity measurements allowed the derivation of $\mathrm{NaCl}$ activity coefficients as a function of temperature.

As a result of the experimental work, Rogers was able to calculate the pressure dependence of activity, enthalpy, and heat capacity. Densities of $\mathrm{NaCl}$ solutions at $2 \mathrm{MPa}$, from $0.05 \mathrm{~m}$ to $4.5 \mathrm{~m}$, and from $75^{\circ} \mathrm{C}$ to $200^{\circ} \mathrm{C}$ were measured using a high-pressure dilatometer. The data obtained from the calorimetry experiment were five times more precise than high-temperature data quoted in the literature. A temperature-dependent fit of heat capacity measurements can, therefore, be used to predict osmotic coefficients and to obtain activity properties of high-temperature electrolyte solutions. Pitzer's equations were tested with recent data obtained on gypsum solubility in ion solutions. The equations not only work on major ion solutions, but also reproduce the properties of minor components in a complex mixture. This finding shows that the Pitzer specific interaction model accurately predicts the properties of electrolytes in natural brines and seawater (at $25^{\circ} \mathrm{C}$ ). Additional high-temperature data are required to test the model at high temperatures.

Silvester, L.F., and K.S. Pitzer (1977), Thermodynamics of Electrolytes: 8. HighTemperature Properties, Including Enthalpy and Heat Capacity, with Application to Sodium Chloride, Journal of Physical Chemistry, 81:1822-1828.

Several thermodynamic properties of aqueous solutions, including the activity coefficients and osmotic coefficients of the individual ions in solution, can be evaluated without explicitly considering ion association (ion pairs) by assigning interaction coefficients, $B_{M X}$, for each combination of a cation $M$ and an anion $X$. This specific ion-interaction model is extended here for wide temperature ranges and is applied to the extensive array of thermodynamic data for aqueous $\mathrm{NaCl}$ from $0^{\circ} \mathrm{C}$ to $300^{\circ} \mathrm{C}$. Results indicate that, at $300^{\circ} \mathrm{C}, \mathrm{NaCl}$ is still a strong electrolyte with little tendency toward formation of ion pairs. Thermodynamic properties at $300^{\circ} \mathrm{C}$, under saturation pressure, are qualitatively similar to those at $25^{\circ} \mathrm{C}$. The greatest change is in the Debye-Hulckel parameter (a fundamental expression in determining interionic forces), a change caused by a significant decrease in the dielectric constant. 
Equations are derived that predict the observed dependency of dissolved $\mathrm{NaCl}$ concentrations on specific temperatures. An essentially complete mathematical determination of the thermodynamic properties of aqueous $\mathrm{NaCl}$ at saturation pressure is presented that provides the necessary background from which to calculate the total enthalpy and entropy of the liquid. Calculations are based on data that refer to the saturation pressure above $100^{\circ} \mathrm{C}$. Below $100^{\circ} \mathrm{C}$ the pressure is a constant $0.1 \mathrm{MPa}$. Tables present osmotic coefficients, enthalpies, heat capacities, and activity coefficients up to $300^{\circ} \mathrm{C}$. Another table summarizes the extensive array of experimental results for aqueous $\mathrm{NaCl}$.

Wood, S.A., D.A. Crerar, S.L. Brantley, and M. Borcsik (1984), Mean Molal Stoichiometric Activity Coefficients of Alkali Halides and Related Electrolytes in Hydrothermal Solutions, American Journal of Science, 284:668-705.

This paper describes the static vapor pressure method for measuring mean molal stoichiometric activity coefficients for $\mathrm{NaCl}$ at $325^{\circ} \mathrm{C}$ and $350^{\circ} \mathrm{C}$ and for $\mathrm{KCl}$ and $\mathrm{CaCl}_{2}$ at $200^{\circ} \mathrm{C}$ and $350^{\circ} \mathrm{C}$. Using a strain-gauge transducer, differential vapor pressures were measured rapidly and accurately. These measurements also determined converted osmotic coefficients, which were fit to Leitzke-Stoughton and Pitzer equations for calculating activity coefficients.

This method of determining activity coefficients provides results that are consistent with theoletical predictions, within experimental error. As shown in Fig. 1 , the method extends the data base for vapor pressures of $\mathrm{NaCl}, \mathrm{KCl}$, and $\mathrm{CaCl}_{2}$ solutions, which allows calculation of activity coefficients ind osmotic coefficients for a variety of electrolytes at elevated temperatures. 

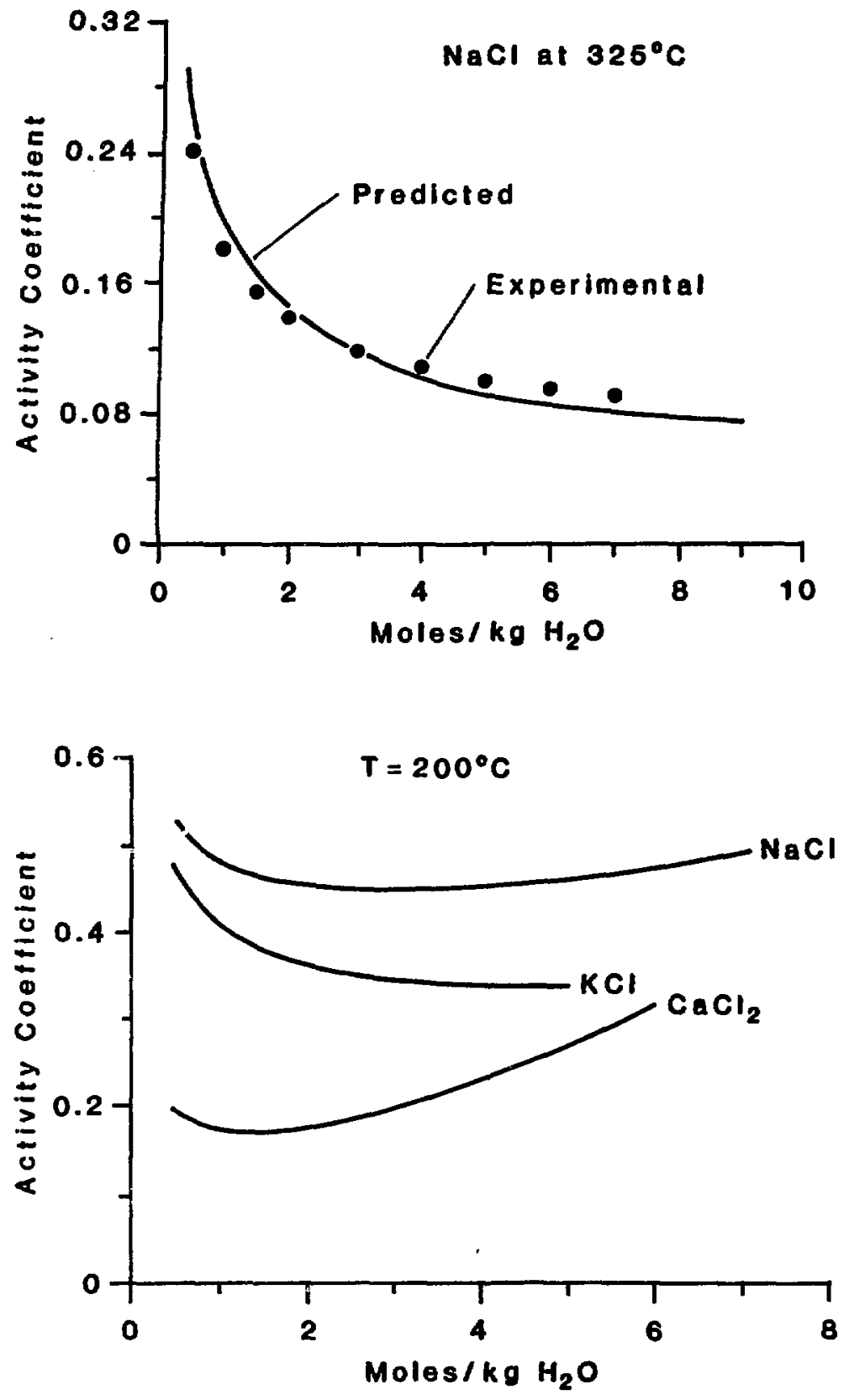

FIGURE 1 Comparison of Calculated Activity Coefficients for $\mathrm{NaCl}$ and Smoothed Activity Coefficients for Alkali Chlorides (Source: Adapted from Wood et al., 1984) 


\section{CHEMICAL EFFECTS OF GAMMA RADLTION}

Burns, W.G., A.E. Hughes, J.A.C. Marples, R.S. Nelson, and A.M. Stoneham (1982), Radiation Effects and the Leach Rates of Vitrified Radioactive Waste, Nature, 295:130-132.

Presented are the results of leaching glass doped with 5 wt. $\%{ }^{238} \mathrm{PuO}_{2}$. The experiments were designed to simulate radiation damage caused by recoil nuclei during $\alpha$ decay. Only modest increases occurred in the leach rate after a radiation dose of $5.6 \times 10^{18} \alpha$-decays/g. However, experiments in which the leaching solution was irradiated with $\gamma$ rays indicated that some members of the resultant chemical species (i.e., $\mathrm{H}^{+}, \mathrm{e}^{-}$ag, $\mathrm{H}, \mathrm{OH}, \mathrm{H}_{2} \mathrm{O}, \mathrm{H}_{2}$, and $\mathrm{H}_{2} \mathrm{O}_{2}$ ) in the irradiated water increased the leach rate of glasses.

Using a $\gamma$-radiation dose rate of $2.4 \mathrm{Mrad} / \mathrm{h}$, the radicals with the highest calculated concentration are $\mathrm{OH}^{\bullet}$ and $\mathrm{O}_{2}{ }^{-}$, with small changes $(<2 \%)$ in the concentrations of $\mathrm{H}^{+}$and $\mathrm{OH}^{-}$. The presence of scavenger solutes $\mathrm{NO}_{3}^{-}$and $\mathrm{Cl}^{-}$, found in waters equilibrated with rocks, can reduce $\mathrm{OH}^{-}$by three orders of magnitude. Because of this, radiolysis of the leachant will not have a large effect on the leach rate in a real repository. It appears that leach rates of irradiated glass under real repository conditions will be no more than a few times larger than for unirradiated glass $\left(1.5-3.0 \mathrm{mg} / \mathrm{cm}^{2} / \mathrm{d}\right)$, depending on temperatures and dosage. The very slow flow rate of water will probably be the ratedetermining factor controlling glass dissolution in the repository environment.

Gray, W.J. (1984), Gamma Radiolysis of Groundwater Found near Potential Radioactive Waste Repositories, Nuclear Waste Management, G.G. Wicks and W.A. Ross, eds., American Ceramic Society Report CONF-830451, pp. 57-61.

Preliminary experimental results are described from irradiating a complex salt brine with $\gamma$ rays. The intensity of the ${ }^{60}$ Co radiation field was $5.5 \times 10^{6} \mathrm{rad} / \mathrm{h}$. The synthetic brine was a WIPP-A-type made to simulate the saturated solution obtained by dissolving salt from a natural bedded deposit. Hydrogen and oxygen gases were generated in a 3:1 ratio at an equilibrium pressure of about $10 \mathrm{MPa}$. Other chemical species produced by radiolysis were $\mathrm{e}_{\mathrm{ag}}^{-}, \mathrm{H}, \mathrm{OH}^{\bullet}$, which can be scavenged by $\mathrm{Br}^{-}$and $\mathrm{Cl}^{-}, \mathrm{H}_{2} \mathrm{O}_{2}$, and $\mathrm{H}_{3} \mathrm{O}^{+}$. State-of-the-art analytical strategies were employed to determine the fate of liberated chlorine. Even with quadrupole mass spectrometer detection limits for chlorine as low as $\mathbf{1 0}$ ppm, no chlorine gas was detected.

Radiolysis of simple single-salt solutions resulted in a similar gas composition $\left(\mathrm{H}_{2} / \mathrm{O}_{2} \sim 3: 1\right)$ but at equilibrium pressures of $2 \mathrm{MPa}$ for the $\mathrm{NaCl}$ solution, 0.3 $\mathrm{MPa}$ for the $\mathrm{NaBr}$ solution, and $0.5 \mathrm{MPa}$ for the $\mathrm{Na}_{2} \mathrm{SO}_{4}$ solution. Single-salt solutions were at the same anionic concentrations as in complex brines. "Synergistic" effects accounted for a fourfold increase in equilibrium pressure from the sum of the single-salt irradiation tests to the complex brine irradiation 
(2.8 $\mathrm{MPa}$ versus $10 \mathrm{MPa}$ ). When the $\mathrm{Cl}^{-}, \mathrm{Br}^{-}$, and $\mathrm{SO}_{4}{ }^{2-}$ components were put into solution together, the pressure generated approximated a complex brine. These phenomena support the vapor migration hypothesis of brine transport.

Gray, W.J., and S.A. Simonson (1985), Gamma and Alpha Radiolysis of Salt Brines, in Scientific Basis for Nuclear Waste Management VIII, C.M. Jantzen et al., eds., Materials Research Society, Pittsburgh, pp. 623-630.

This report of ongoing research deals with the effects of $r$ and $\alpha$ radiation on Permian basin brines. Equilibrium gas pressures were evaluated after irradiation at varying temperatures. Alpha radiation produced higher equilibrium gas pressures than $\gamma$ radiation.

A radiolysis computer code (MAKSIMA-CHEMIST) helped to model the experimental results. Using published data, the computer code did not coincide with values obtained experimentally, probably because rate constants for the Permian basin brine were not specifically determined. After adjustments, the calculated $\alpha$ dose rate was too high by 25\%. Apparently, 25\% of the $\alpha$ energy is deposited in particles suspended in the brine. Further modeling efforts should help to explain the synergistic effects of anionic species in these brines.

Jain, U., and A.B. Lidiard (1977), The Growth of Colloidal Centers in Irradiated Alkali Halides, Philosophical Magazine, 35:245-259.

Presenting what many consider to be the definitive theory explaining radiation damage in rock salt, this paper adequately describes some of the resultant chemical changes in salt and establishes the following mechanism for radiationinduced growth of colloid particles in $\mathrm{NaCl}$.

1. After colloid particles have been nucleated, the particles become sinks for diffusing radiation-induced $F$-centers ( $F$ standing for the German word "Farbe" [color]) and vacancies. The $\mathrm{F}$-center is caused by cumulative $\mathrm{Cl}$ vacancies in the $\mathrm{NaCl}$ lattice.

2. The vacancy or F-center arriving at the colloid-particle/ $\mathrm{NaCl}$ lattice interface removes one $\mathrm{Cl}$ atom from the $\mathrm{NaCl}$ lattice and releases one $\mathrm{Na}$ atom to the newly forming Na metal lattice.

3. The F-c enter and vacancy diffusion rate, as well as the dissolution of $\mathrm{Na}$ atoms from the colloidal system into the $\mathrm{NaCl}$ lattice, inereases with increasing temperature. This increase theoretically results in the colloid formation rate increasing with increasing temperature to a maximum and then decreasing. (Experimentally, the rate plateau is from approximately $150^{\circ} \mathrm{C}$ to $175^{\circ} \mathrm{C}$.) 
The theory breaks down by not predicting the pronounced colloid formation induction period. Also, it does not quite provide an adequate theoretical background for the radiation-damage kinetics necessary to establish a foundation for reliable modeling of the radiation damage in rock salt surrounding radioactive waste canisters.

Jenks, G.H. (1972), Radiolysis and Hydrolysis in Salt-Mine-Brines, Oak Ridge National Laboratory Report ORNL-TM-3717, 99 pp.

The objective of this treatise was to review and analyze pertinent theoretical and experimental information and to identify and quantify the rates of formation of bothersome decomposition products.

Salt decrepitation is a potential facilitator of brine migration at temperatures starting at about $250^{\circ} \mathrm{C}$. Fracturing of salt at high temperatures is thought to be a result of the high vapor pressure of water within brine inclusions and the strain caused by the thermal expansion of liquid within cavities.

Jenks specifically studied the effects of $\gamma$ radiation in salt and the resultant trapped electrons (reducing agents) and holes (oxidizing agents) on brine migration. He predicts that thermal annealing will limit the amount of energy storage to several calories per gram when the exposure temperature is higher than $200-250^{\circ} \mathrm{C}$.

The appendixes, which constitute two-thirds of the volume, discuss (1) the composition of brine, (2) the determination of the number of molecules that appear as a final product per $100 \mathrm{eV}$ of ubsorbed energy (G-values), (3) the determination of the number of species appearing in homogeneous distribution in the initial radiation-decomposition per $100 \mathrm{eV}$ of absorbed energy ( $g^{\prime}$-values), (4) the identities of the oxidized species formed radiolytically, (5) the extent of hydrolysis and pyrolysis of brine salts around the waste canister, (6) the inflow of brine by cavity migration, and (7) estimates of radiation dose to and total hydrogen generation in a migrating brine.

Jenks, G.H., E. Sonder, C.D. Bopp, J.R. Walton, and S. Lindenbaum (1975), Reaction Products and Stored Energy Released from Irradiated Sodium Chloride by Dissolution and by Heating, Journal of Physical Chemistry, 79:871-875.

Heat-of-solution and drop calorimetry were used to measure stored energy in irradiated $\mathrm{NaCl}$ and other solids. The stored energy per radiation-activated molecule of $\mathrm{NaCl}$ is approximately equal to the heat of formation of $\mathrm{NaCl}$ from its elements. The following were experimentally determined: (1) heat release upon thermal bleaching, (2) heat release upon dissolution of irradiated samples, (3) identity and quantity of gases evolved during aqueous dissolution, and (4) concentrations of hypochlorite ion in solutions of irradiated salt. Aqueous dissolution of $\mathrm{NaCl}$ may be affected by previous $\gamma$ irradiation of the salt. 
Included is a table of possible dissolution reactions of trapped electrons and holes. The reaction between irradiation-activated $\mathrm{NaCl}$ molecules and $\mathrm{H}_{2} \mathrm{O}$ produces $\mathrm{OCl}^{-}, \mathrm{HOCl}, \mathrm{H}_{2}, \mathrm{Na}^{+}$, and $\mathrm{Cl}^{-}$as the principal solution products.

Figures summarize the concentration of dissolution reaction products of irradiated salt and the values of stored energy as a function of radiation dosage. For example, at a rock salt temperature of $95^{\circ} \mathrm{C}$ and a radiation dosage of $3 \times$ $10^{10} \mathrm{red}, 6 \times 10^{20} \mathrm{eV}$ of energy is stored and about $110 \mathrm{\mu mol}$ of $\mathrm{OCl}^{-}$is produced per gram of rock salt. Primary dissolution reactions include:

$$
\begin{aligned}
& \mathrm{Na}^{+} \mathrm{e}^{-}+\left(\mathrm{Cl}^{-}\right)^{+}+\mathrm{Na}^{+}+\mathrm{Cl}^{-} \\
& \mathrm{Na}^{+} \mathrm{e}^{-}+\mathrm{H}_{2} \mathrm{O} \rightarrow 1 / 2 \mathrm{H}_{2}+\mathrm{Na}^{+}+\mathrm{OH}^{-} \\
& \left(\mathrm{Cl}^{-}\right)^{+}+1 / 2 \mathrm{H}_{2} \mathrm{O} \rightarrow 1 / 2 \mathrm{Cl}^{-}+1 / 2 \mathrm{H}^{+}+1 / 2 \mathrm{HOCl} \\
& \mathrm{HOCl}+\mathrm{H}^{+}+\mathrm{OCl}^{-} \quad\left(\mathrm{K}=3 \times 10^{-8}\right)
\end{aligned}
$$

Jockwer, N. (1984), Laboratory Investigations on Radiolysis Effects on Rock Salt with Regard to the Disposal of High-Level Radioactive Wastes, in Scientific Basis for Nuclear Waste Management VII, G.L. McVay, ed., Elsevier, New York, pp. 17-25.

Four different evaporites were examined for their gas-generating potential both in and out of a 150-Mrad radiation field: $95 \mathrm{wt} . \%$ halite and $5 \mathrm{wt}$. $\%$ anhydrite, polyhalite, and kieserite; pure gypsum; polyhalitic rock salt; and kieserite with $2 \%$ halite. The water content of these samples ranged from $0.3 \mathrm{wt}$. $\%$ to $21 \mathrm{wt}$. \%. The major ef fect of increasing bound-water concentration appeared to be an increase in hydrogen generation. Experimental results of $\gamma$ radiolysis at elevated temperatures (up to $320^{\circ} \mathrm{C}$ ) of rock salt from the Asse mine indicated that the following gas components and concentrations (dependent on mineral composition) will be generated: (1) $\mathrm{CO}_{2}$ up to $400 \mathrm{ppm},(2) \mathrm{H}_{2} \mathrm{~S}$ up to $5 \mathrm{ppm},(3) \mathrm{HCl}$ up to 150 ppm, (4) gaseous hydrocarbons $\left(\mathrm{CH}_{4}, \mathrm{C}_{2} \mathrm{H}_{6}\right.$, and hydrocarbons above $\left.\mathrm{C}_{2}\right)$ up to $60 \mathrm{ppm},(5) \mathrm{H}_{2}$, and (6) $\mathrm{O}_{2}$.

Radiolytic cracking of higher hydrocarbons produced $\mathrm{CH}_{4}$; subsequent oxidation of hydrocarbons formed $\mathrm{CO}_{2}$. These concentrations were compared to those collected by field work at the Asse mine. Those experiments measured, at natural mine temperatures, the gas liberated from Strassfurt halite into sealed boreholes and into the ventilation air.

Levy, P.W. (1983), Radiation Damage Studies on Natural Rock Salt from Various Geological Localities of Interest to the Radioactive Waste Disposal Program, Nuclear Technology, 60:231-243.

Colloid formation was studied in 14 "naturally impure" rock salt samples (chosen from locations that are potential repository sites and from different horizons at 
chosen localities) under conditions optimizing the rate of colloid formation. These samples were as free as possible from voids, discolored areas, macroscopic defects, and strain-induced plastic deformation. The major variation that remained was chemical impurity.

All measurements were made in a temperature-controlled irradiation chamber with $1.5-\mathrm{MeV}$ electron bombardment. Electron bombardnent is much like $\gamma$-rayinduced damage because the principal interaction between $\gamma$ rays and solids is formation of Compton and photoelectric recoil electrons. Dose rate was $1.2 \times$ $10^{8} \mathrm{rad} / \mathrm{h}$. Total doses measured were $2 \times 10^{8}$ rad to $4 \times 10^{8} \mathrm{rad}$, with the temperature controlled to $150^{\circ} \mathrm{C}$. As a result, $\mathrm{Na}$ atoms precipitated out of the crystalline $\mathrm{NaCl}$ matrix to form metal particles imbedded in a salt. The "colloid" absorption band formed from this process was influenced by the shape and size of colloid particles.

Factors influencing radiation-induced colloid formation in natural rock salt include:

1. Plastic deformation in which straining decreases the induction period. No induction period exists at $10 \%$ strain.

2. Different dose rates. Colloid formation increases as dose rate decreases.

3. Lattice impurities. Colloid formation is suppressed if impurities include greater than $1 \%$ Ca or S.

4. Temperature effects.

a. Low doses at room temperature form the F-center band (indicating $\mathrm{Cl}^{-}$ vacancies) and several $\mathrm{V}$-region bands (indicating a negative halogen molecule ion $\mathrm{Cl}_{2}{ }^{-}$). The colloid growth induction period is about 3-6 mo.

b. High doses at over $100^{\circ} \mathrm{C}$ create immediate F-center formation, with the rate plateauing at $10^{6}-10^{7}$ rad. Where the F-center absorption band plateaus, the $M$-center absorption band (indicating two adjacent $F$ centers) begins to be observed.

c. At $115^{\circ} \mathrm{C}$, the threshold temperature that is necessary for the colloidal $\mathrm{Na}$ to begin "crystallizing" is reached.

d. At $175^{\circ} \mathrm{C}$, the colloid formation rate is maximal.

e. At $250-300^{\circ} \mathrm{C}$, the colloid formation rate drops to a negligible level.

It can be predicted that in $50-400 \mathrm{yr}$, rock salt at the canister surface will contain $0.1-10 \%$ colloidal $\mathrm{Na}$ metal at a total dose of $\sim 1 \times 10^{10} \mathrm{rad}$ and $1-50 \%$ metal at a total dose of $\sim 2 \times 10^{10}$ rad if (1) the buried radioactive waste canister 
is largely unshielded, (2) the initial dose rate at its surface spproximates $2 \times 10^{4}$ $\mathrm{rad} / \mathrm{h}$, ani (3) the salt temperature is $150^{\circ} \mathrm{C}$. At approximately $0.5 \mathrm{~m}$ from the canister surface, the damage levels will be reduced by a few percent.

Levy, P.W., J.M. Loman, and J.A. Kierstead (1984), Radiation Induced F-Center and Colloid Formation in Synthetic $\mathrm{NaCl}$ and Natural Rock Salt: Applications to Radioactive Waste Repositories, Nuclear Instruments and Methods in Physics Research, B1:549-556.

Results from the continuation of earlier experimental work are presented. Optical absorption and luminescence were measured during irradiation with 1-3-MeV electrons under thermal conditions controlled to within $1 \mathrm{C}^{\circ}$. A constant temperature of $150^{\circ} \mathrm{C}$ was used because no method exists for scaling time-temperature profiles. Again, chlorine was not detected. If chlorine is released, then it is less likely that back reactions can occur and more likely that Na metal colloid formation will be stabilized or accelerated. Experimental conditions are compared with the anticlpated repository conditions in Table 4.

A schematic diagram of a typical waste canister and the surrounding salt illustrates the anticipated thickness of surrounding colloidal $\mathrm{Na}$ metal for given dosages. Each lightly shielded high-level radioactive waste canister may ultimately be surrounded by $200-300 \mathrm{~kg}$ of colloidal Na. This configuration is probably not geologically stable and will dissolve in brine solutions.

Loman, J.M., P.W. Levy, and K.J. Swyler (1982), Radiation-Induced Sodium Metal Colloid Formation in Natural Rock Salt from Different Geological Localities, in Seientific Basis for Nuclear Waste Management VI, S.V. Topp, ed., Elsevier, New York, pp. 433-440.

Radiation damage in natural rock salt from various localities is described. Colloid-concentration versus irradiation-time curves follow classical nucleation and growth curves and are accurately described by $\mathrm{Ct}^{\mathrm{n}}$ or $\mathrm{C}(\text { dose })^{\mathrm{n}}$ relations at large iriadiation times, where $t$ is the irradiation time and $n$ is a constant of

TABLE 4 Experimental and Anticipated Repository Conditions

\begin{tabular}{lcc}
\hline Variable & Experimental Conditions & Repository Conditions \\
\hline $\begin{array}{l}\text { Dose rate } \\
\text { Final dosage } \\
\text { Temperature }\end{array}$ & $\begin{array}{c}0.3 \times 10^{8} \text { to } 1.2 \times 10^{8} \mathrm{rad} / \mathrm{h} \\
2 \times 10^{8} \text { to } 4 \times 10^{8} \mathrm{rad} \\
150^{\circ} \mathrm{C}\end{array} \begin{array}{c}1 \times 10^{4} \text { to } 2 \times 10^{10} \text { to } 2 \times 10^{4} \mathrm{rad} / \mathrm{h} \\
50^{\circ} \mathrm{C} \text { to } 250(?)^{\circ} \mathrm{C}\end{array}$
\end{tabular}

Source: Levy et al., 1984. 
value $1.85 \pm 0.18$. In other words, the amount of $\mathrm{NaCl}$ that is converted to $\mathrm{Na}$ metal can be expressed as:

mol $\%$ Na metal $=4.42 \times 10^{-7} \mathrm{C}(\text { dose })^{\mathrm{n}}$

where $C$ and $n$ are constants derived from the relationship that $\mathrm{Na}^{+} \mathrm{e}^{-}$( $\mathrm{Na}$ colloid $)=C(\text { dose })^{\mathrm{n}}$, and $\mathrm{C}$ is an experimentally determined parameter related to sample strain, impurity, void content, and dose rate, whose value can vary by three orders of magnitude. After an irradiation dose of $3.3 \times 10^{8} \mathrm{rad}$, the colloid content of the 14 different natural rock salt samples examined varied by a factor of 80. Although not explored at any length, this variation was apparently due to chemical impurities. When the mole percent $\mathrm{NaCl}$ converted to colloidal $\mathrm{Na}$ reaches $10 \%$ (possible at $10^{10}$ rad, $150^{\circ} \mathrm{C}$ or predicted repository conditions in $10-1000 \mathrm{yr}$ ), the salt becomes hard and brittle, possesses no sheer strength, and is almost friable.

Markham, J.J. (1966), F-Centers in Alkali Halides, Academic Press, New York, 400 pp.

Mechanisms and results of $\mathrm{F}$-center formation are described in detail, creating a classical treatise on the effects of irradiation on alkali halides. Most of the experimental aspects of the F-center research are presented.

Coloration varies from one alkali halide to another (brown + black + red), depending on iemperature and irradiation dose, and is caused by a combination of injected electrons and negative vacancies. The associated absorption band, the F-band, is caused by F-center lattice imperfections. A pair of ion vacancies is produced per F-center in the later stages of coloration at room temperature. The energy required to impart $25 \mathrm{eV}$ to $\mathrm{a} \mathrm{Cl}^{-}$ion (thus producing a direct ionic vacancy) is $645 \mathrm{keV}$ from a photon or $400 \mathrm{keV}$ from an electron.

Results are presented from theoretical and experimental investigations of equilibrium between colloid and F-centers. This two-phase system is treated in some detail. It is interesting to note that a fractional volume expansion accompanies F-center formation. Although much of the book is couched in the jargon of solid state physics and F-center formation is explained from a quantum mechanical viewpoint, it contains a wealth of information pertinent to the isolation of radioactive waste in salt.

Panno, S.V., and P. Soo (1984), Potential Effects of Gamma Irradiation on the Chemistry and Alkalinity of Brine in High-Level Nuclear Waste Repositories in Fock Salt, Nuclear Technology, 67:268-281.

Rock salt samples from the Salado Formation near Carlsbad, New Mexico, were irradiated under three different experimental conditions: ambient temperatures and pressures, $125^{\circ} \mathrm{C}$ in a dry state, and $125^{\circ} \mathrm{C}$ with saturated brine. The color of rock salt after irradiation was a mixture of amber (reflecting F-center formation) and blue (reflecting Na-colloid formation). 
The brine has the potential to become acidic, basic, or possibly both, but at different times during the emplacement period. Radiolysis of rock salt and subsequent dissolution produces a very basic brine. Rock salt samples from the MeNutt member of the Salado Formation (90\% halite, 5\% sylvite, and 5\% polyhalite), obtained from a bedded salt deposit near Carlsbad, New Mexico, and irradiated dry at $40^{\circ} \mathrm{C}$ to doses between $10^{7}$ and $10^{10}$ rad, produced brines with $\mathrm{pH}$ values as high as 9.25. When irradiated at $125^{\circ} \mathrm{C}$, $\mathrm{pH}$ values reached 9.6, increasing as at $40^{\circ} \mathrm{C}$ with radiation dosage. The $\mathrm{pH}$ of such solutions can be considered a measure of the total radiation-induced colloid in the irradiated salt. The data indicate that, after an induction period and until a radiation dose of about $3 \times 10^{8}$ rad is reached, colloidal concentrations increase as a power-law function for doses up to $10^{10}$ rad. A linear increase in hydrogen generation and $\mathrm{OCl}^{-}$in solution with increasing radiation dose is consistent with $\mathrm{Na}$ colloid and $\mathrm{Cl}_{2}{ }^{-}$aggregate formation and occurs according to the following reactions:

$$
\begin{aligned}
& \mathrm{Na}^{+} \mathrm{e}^{-}+\mathrm{H}_{2} \mathrm{O} \rightarrow 1 / 2 \mathrm{H}_{2}+\mathrm{Na}^{+}+\mathrm{OH}^{-} \quad(\mathrm{pH} \text { can increase to }>14) \\
& \left(\mathrm{Cl}^{-}\right)^{+}+1 / 2 \mathrm{H}_{2} \mathrm{O} \rightarrow 1 / 2 \mathrm{Cl}^{-}+1 / 2 \mathrm{H}^{+}+1 / 2 \mathrm{HOCl} \\
& \mathrm{HOCl} \rightarrow \mathrm{H}^{+}+\mathrm{OCl}^{-}
\end{aligned}
$$

Crushing and annealing of irradiated rocks prior to dissolution increases $\mathrm{pH}$ from $9.3+$ to $10.1+$, perhaps due to the effect of releasing chlorine gas. When the brine and rock salt are irradiated together at $125^{\circ} \mathrm{C}$, the irradiated brine becomes progressively more acidic, while the brine made from the subsequent dissolution of the irradiated rock becomes more basic. The acidity of brine irradiated with rock salt could be explained by the following reactions:

Release of $\mathrm{CO}_{2}, \mathrm{H}_{2} \mathrm{~S}, \mathrm{HCl}$, and $\mathrm{SO}_{2}$ from rock salt to form an acidic solution

$$
\begin{aligned}
2 \mathrm{Cl}_{2}+2 \mathrm{H}_{2} \mathrm{O}+ & 4 \mathrm{HCl}+\mathrm{O}_{2} \\
3 \mathrm{Cl}_{2}+6 \mathrm{NaOH} \rightarrow & \mathrm{NaClO}_{3}+5 \mathrm{NaCl}+3 \mathrm{H}_{2} \mathrm{O} \\
& \downarrow \\
& 1 / 4 \mathrm{NaCl}+3 / 4 \mathrm{NaClO}_{4}
\end{aligned}
$$

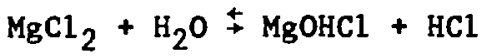

Both thermal and irradiation effects are likely to alter significantly the corrosion environment for a waste package embedded in a salt repository. Alkaline or acidic conditions may be present, depending on whether the package is shielded or unshielded against irradiation and on the quantity of brine present during the high $\gamma$-irradiation period. 
Patil, S.F., D. Ravishankar, P. Bhatia, and I.B. Chowdhary (1984), Chemical Effects Induced by Gamma-Irradiated Salts in Aqueous Medium, International Journal of Applied Radiation and Isotopes, 35:459-462.

Although much work has focused on the corrosive effects anticipated by the oxidative capacity of released oxygen gas, little emphasis has been placed on the chemical reducing effects of irradiation. However, the results presented in this article may be pertinent to complex brines containing redox-sensitive species such as sulfates. Conclusions are presented from an experimental study in which $\gamma$-irradiated $\mathrm{NaCl}\left(1 \times 10^{19} \mathrm{eV} / \mathrm{g}\right)$ is dissolved in a $0.05 \mathrm{M} \mathrm{NaNO}_{3}$ solution at room temperature. The $\mathrm{NaNO}_{3}$ was reduced to $\mathrm{NaNO}_{2}$, with the $\mathrm{NaNO}_{2}$ yield inversely proportional to the particle size of $\mathrm{NaCl}$. $A$ $Y$ dose of $2 \times 10^{20} \mathrm{eV} / \mathrm{g}$ produced $1.91 \times 10^{18} \mathrm{~F}$-centers $/ \mathrm{mol}$. Experimental values were close to theoretical values. The theoretical F-center concentration can be calculated from the mass of $\mathrm{NO}_{2}^{-}$ions formed per mass of salt according to the following reactions:

$$
\begin{aligned}
& 2 \mathrm{~F}^{\mathrm{H}_{2}} \stackrel{\mathrm{O}}{\rightarrow} 2 \mathrm{e}_{\mathrm{aq}}^{-} \\
& 2\left(\mathrm{e}_{\mathrm{aq}}^{-}+\mathrm{NO}_{3}^{-}\right)+2 \mathrm{NO}_{3}{ }^{2-}+2\left(\mathrm{NO}_{2}\right)_{\mathrm{aq}}+\mathrm{NO}_{3}^{-}+\mathrm{NO}_{2}^{-}+2 \mathrm{H}^{+}
\end{aligned}
$$

Pederson, L.R. (1985), Chemical Implications of Heat and Radiation Damage to Rock Salt, in Scientific Basis for Nuclear Waste Management VIII, C.M. Jantzen et al., eds., Materials Research Society, Pittsburgh, pp. 701-708.

Both synthetic salts and natural salts from the Palo Duro and Paradox basins were heated to $300^{\circ} \mathrm{C}, \gamma$-irradiated, and both heated and irradiated. Although heating caused no effects on the synthetic salts, the natural salts were damaged by both heating and irradiation. The effects from irradiation alone were the formation of $\mathrm{Na}$-colloids and neutral chlorine, whereas heating caused liberation of $\mathrm{HCl}, \mathrm{SO}_{2}, \mathrm{CO}_{2}$, and $\mathrm{H}_{2} \mathrm{~S}$. Heating of irradiated samples caused recombination of radiation-induced defects, evolution of neutral chlorine, and liberation of $\mathrm{HCl}$, $\mathrm{SO}_{2}, \mathrm{CO}_{2}$, and $\mathrm{H}_{2} \mathrm{~S}$. The liberation of $\mathrm{HCl}$ is most significant and is attributed to heating effects. It may be transported via brine migration and cause damage by reacting with the overpack material or the waste package itself. Escape of acidic $\mathrm{HCl}$ gases increases the $\mathrm{pH}$ of the remaining salt. The $\mathrm{pH}$ of brines could thus be significantly changed by heat damage to rock salt.

Simonson, S.A., and W.L. Kuhn (1984), Predicting Amounts of Radiolytically Produced Species in Brine Solutions, in Scientific Basis for Nuclear Waste Management VII, G.L. McVay, ed., Elsevier, New York, pp. 17-25.

The computer code RADIOL predicts the concentrations of radiolytically produced species in brines as a function of time. The modeling results presented 
are based on published radiation yields of species, chemical reaction rate constants, and other experimentally derived parameters. Tables are presented of overall G-values for $\gamma$-irradiated aqueous solutions and 39 chemical reactions and their associated rate constants used for predicting concentrations of radiolytically produced species in brines.

Graphs of time versus species produced radiolytically at a dose rate of 3.5 $\mathrm{Mrad} / \mathrm{h}$ and an initial oxygen concentration of $1.5 \mathrm{ppm}$ suggest an initial transient period (1-20 s) during which the concentrations of the more highly reactive radiolysis products are changing repialy toward a dynamic equilibrium. At steady state, the concentrations of the minor constituents of the brine (i.e., $\mathrm{Cl}^{\bullet}, \mathrm{H}^{\bullet}$, $\mathrm{HO}_{2}{ }^{-}, \mathrm{O}_{2}^{-}, \mathrm{HO}_{2}$, and $\mathrm{OH}^{\bullet}$ ) are controlled by the behavior of the major constituents (i.e., $\mathrm{H}^{+}, \mathrm{H}_{2} \mathrm{O}_{2}, \mathrm{H}_{2}$, and $\mathrm{O}_{2}$ ). Anticipating such compositional changes as a function of irradiation is important because corrosion of $\mathrm{Fe}$ overpack materials is highly sensitive to rajiolytic products such as $\mathrm{HCl}$ and $\mathrm{H}_{2} \mathrm{~S}$. Models of uniform corrosion in irradiated brines are being developed in which the corrosion rate depends on the radiolytically induced concentration of oxidizing species in solution.

Weber, W.J., L.R. Pederson, W.J. Gray, and G.L. MeVay (1984), Radiation Effects on Nuclear Waste Storage Materials, Nuclear Instruments and Methods in Physics Research, B1:527-533.

This paper reviews, in the context of previous publications, recently reported data on the effects of radiation on nuclear waste packages, the corrosive effects of solution radiolysis, and the effects of radiation on rock salt. Preliminary evidence indicates that the leach rates in waste glasses should be accelerated by no more than a factor of five by radiolysis. The leaching effect of radiolysis is essentially temperature independent.

In a study of $\gamma$ radiolysis of brines, the composition of the resultant released gases in all cases was about $67 \%$ hydrogen and $33 \%$ oxygen. No chlorine gas was detected. The equilibrium pressure was much higher for the brine than from the sum of pressures produced by the individual brine components. Either experimental or chemical uncertainties must be responsibie for this anomaly. Colloid formation can be estimated under postulated repository conditions if the effects of radiation dose rate and trends towards $F$-center saturation are ignored. Maximum stored energy in rock salt occurs from $95^{\circ} \mathrm{C}$ to $144^{\circ} \mathrm{C}$, a temperature range slightly lower than $150^{\circ} \mathrm{C}$, the optimal formation temperature for colloids. Thermally ectivated annealing dominates at temperatures above $150^{\circ} \mathrm{C}$ and reduces the amount of stored energy. 


\section{BRINE MIGRATION STUDIES}

Anthony, T.R., and H.E. Cline (1971), Thermal Migration of Liquid Droplets through Solids, Journal of Applied Physics, 42:3380-3387.

This article is often considered to present the most groundbreaking model of thermal migration of brine inclusions. In the experimental methodology, $\mathrm{KCl}$ crystals were used as the migration matrix, and both large $(>200 \mu \mathrm{m})$ and small $(5-150 \mu \mathrm{m})$ droplets were studied under a thermal gradient of $22^{\circ} \mathrm{C} / \mathrm{cm}$. According to the formulated model, the migration velocity, $V$, of brine inclusions in polycrystalline salt represents the sum of four components:

$v=v_{\tau}+v_{\sigma}-v_{k}-v_{\gamma}$

where:

$V_{\tau}=$ velocity due to ordinary (concentration gradient) diffusion,

$V_{\sigma}=$ velocity due to thermal diffusion (Soret effect),

$V_{K}=$ velocity due to kinetics of dissolution and crystallization of the salt at the salt brine interface, and

$V_{Y}=$ velocity due to surface tension at grain boundaries.

However, because some diffusion coefficients of salt in brines are not known, determination of the Soret coefficient at elevated temperatures is very problematic.

Biggers, J.V., and G.O. Dayton (1982), Brine Migration in Hot-Pressed Polycrystalline Sodium Chloride, Office of Nuclear Waste Isolation Report ONWI-415, Battelle Memorial Institute, Columbus, Ohio, 88 pp.

Experiments are described that were designed to provide data on brine migration in polycrystalline salt and, more specifically, to delineate the effects of grain boundaries on the mechanism and rates of brine migration. The test designs varied primarily in the way in which the thermal gradient was applied and monitored and in the determination of brine migration. Three different types of migration cells were used, with the resultant thermal gradient variation ranging from $4^{\circ} \mathrm{C} / \mathrm{cm}$ to $120^{\circ} \mathrm{C} / \mathrm{cm}$.

Using hot-pressed polycrystalline salt as the migration matrix ensured carefully controlled microstructures that included defects (e.g., grain-boundary porosity, dislocation density, impurity ions, and second phase) also found in natural salts. Addressing the problem of how the microstructure $(0.2-10 \mathrm{~mm})$ of salt influences the migration velocities, Biggers and Dayton found that the measured migration 
velocity in dense polycrystalline salt (42-67 $\mathrm{cm} / \mathrm{yr})$ may be at least an order of magnitude greater than that suggested by single-crystal experiments. The driving force for brine migration includes not only the temperature gradient but also other areas of high chemical activity, such as grain boundaries, areas of high dislocation density, second-phase interfaces, and areas of high concentrations of impurities. Similarly, the actual paths of the brine inclusions are influenced by nany factors: (1) brine inclusion size, shape, and velocity; (2) nature of boundaries and interfaces; (3) interfacial energies; and (4) average temperature and temperature gradient.

Chou, I.M. (1982), Migration Rates of Brine Inclusions in Single Crystats of $\mathrm{NaCl}$, in Scientific Basis for Nuclear Waste Management VI, S.V. Topp, ed., Elsevier, New York, pp. 303-310.

Brine inclusions in rock salt migrate toward a heat source such as radioactive wastes via a three-step pathway: (1) dissolution of salt at the hot side of the salt-brine interface, (2) ion diffusion through the brine droplet, and (3) precipitation of salt at the cold side of the salt-brine interface. At $100^{\circ} \mathrm{C}$, experimental results are quite consistent among research groups. The values given in Table 5 reflect this consistency and the impact of inclusion size.

Experimentally measured migration rates do not compare well with values predicted from Anthony and Cline's (1971) model for all-liquid brine inclusions in single crystals of $\mathrm{NaCl}$. The reasons for this discrepancy are that (1) interface kinetics acting as a retarding factor are neglected in the calculations; (2) the model ignores that migration rate is a function of inclusion size; and (3) available data indicate that the Soret coefficient for $\mathrm{NaCl}$ is insensitive to concentration of solution, but is extremely sensitive to temperature. Examining theoretical calculations of maximum migration rates of four brine compositions results in the following statement about relative velocities:

$\mathrm{NaCl}-\mathrm{H}_{2} \mathrm{O}>$ WIPP-A $>$ halite-saturated $>2.41 \mathrm{MgCl}_{2}>\mathrm{NBT}-6$

TABLE 5 Experimental Brine Migration Rates

\begin{tabular}{ccc}
$\begin{array}{c}\text { Size of } \\
\text { Inclusion }\left(\mu \mathrm{m}^{3}\right)\end{array}$ & \multicolumn{2}{c}{ Migration Velocity $\left(\mathrm{cm}^{2} / \mathrm{yr}^{\circ}{ }^{\circ} \mathrm{C}\right)$} \\
\cline { 2 - 3 } & Experiment 1 & Experiment 2 \\
\hline $2,250,000$ & 0.32 & 0.37 \\
274,625 & 0.18 & 0.13 \\
\hline
\end{tabular}

Source: Chou, 1982. 
The $\mathrm{NaCl}-\mathrm{H}_{2} \mathrm{O}$ and $\mathrm{NBT}-6$ brines represent the fastest and slowest moving inclusions, respectively.

Gnirk, P.S., W.B. Krause, and A.S. Fossura (1981), State-of-the-Art Review of Brine Migration Studies in Salt, Sandia National Laboratories Technical Memorandum Report RSI-0075, SAND-81-7054, 52 pp.

This report reviews fundamental early work conducted on salt inclusions and fluid migration in salt. The authors analyze the shortcomings of previous investigations and suggest experiments to properly model fluid flow in a salt repository. The studies under discussion all deal with single-phase and bi-phase migration in single crystals of salt.

Bradshaw and Sanchez (1969)* experimentally determined that the driving force of thermally induced brine migration is the difference in solubility between the warm and cold sides of a brine cavity. Dissolution occurring on the side of a cavity near the heat source, together with precipitation on the opposite side, causes migration toward the heat source. Total brine migration was estimated from data gathered at Project Salt Vault, an early test site. A maximum water inflow rate of $3.6 \mathrm{~mL} / \mathrm{d}$ was calculated for 1 yr af ter waste emplacement. After a projected 20-30 yr, the migration rate approached zero, and $15 \mathrm{~L}$ of water per emplacement hole had been mobilized. Migration increased proportionally with temperature up to $200^{\circ} \mathrm{C}$; at higher temperatures, migration was faster than predicted due to developmerit of microf ractures.

Anthony and Cline's (1971) experiments concurred with those of Bradshaw and Sanchez (1969), but they felt that the nonlinear behavior of migration at high temperatures is due to the influence of interface kinetics on "droplet" velocity, and "droplet" shape and its change with velocity. Chen and Wilcox $(1972)^{\ddagger}$ found that dissolution at the hot end of an inclusion is Fuster than precipitation at the cold end, causing the inclusion to elongate and eventually break up.

In experiments with fluid and vapor phase inclusions, Anthony and Cline (1971) found that bi-phase inclusions travel away from the heat source. If an inclusion is heated to its boiling point, formation of gas at the hot end causes the inclusion to move in the opposite direction. Two important observations made by Powers et al. $(1978)^{\S}$ are that application of a deviatoric stress changes the volume and

*Bradshaw, R.L., and F. Sanchez (1969), Migration of Brine Cavities in Rock Salt, Journal of Geophysical Research, 74(17):4209-4212.

${ }^{\ddagger}$ Chen, K.-H., and W.R. Wilcox (1972), Boiling and Convection during Movement of Solvent Inclusions in Crystals, Industrial and Engineering Chemistry, 11:563-565.

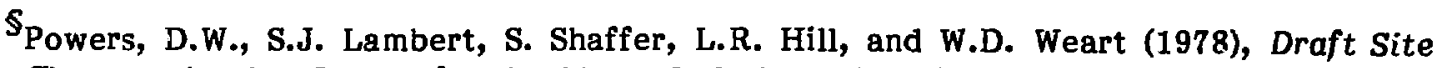
Characterization Report for the Waste Isolation Pilot Plant (WIPP), Southeastern New Mexico, Vol. II, Sandia Laboratories Report SAND-78-1596. 
shape of inclusions, and thus the migration rate, and that a geothermal gradient threshold must be exceeded before the brine migrates.

A theoretical description of the behavior of single-phase fluid migration in salt was attempted by Bradshaw and Sanchez (1969) and Anthony and Cline (1971). However, the equations derived by each investigator depend on the StokesEinstein equation for their derivation, which Gnirk et al. believe invalidates the application to brine migration. The Stokes-Einstein equation applies only to large, rigid spherical particles. Equations for bi-phase inclusion migration are derived by Anthony and Cline (1971). Gnirk et al. believe that the migration rate of brine inclusions in salt is a function of the following form:

$V=F\left\{f_{0}(T) ; f_{1}(\Delta T / \Delta X) ; f_{2}\right.$ (chemistry); $\left.f_{3}(\sigma) ; f_{4}(\eta) ; f_{5}(\varepsilon)\right\}$

where:

$$
\begin{aligned}
V= & \text { rate of brine migration, } \\
f_{0}(T)= & \text { functional relation involving salt temperature, } \\
f_{1}(\Delta T / \Delta X)= & \text { functional relation involving imposed thermal gradient, } \\
f_{2} \text { (chemistry) = } & \text { functional relation involving the chemical composition and } \\
& \text { reaction of the brine and salt as well as additional } \\
& \text { minerals (e.g., at grain boundaries), } \\
f_{3}(d)= & \text { functional relation involving stress state, } \\
f_{4}(n)= & \text { functional relation involving inclusion size, shape, and } \\
& \text { distribution parameters, as well as crystal size, shape, and } \\
& \text { distribution, and } \\
f_{5}(\varepsilon)= & \text { functional relation involving kinetic influence of grain } \\
& \text { boundaries. }
\end{aligned}
$$

To develop the constitutive law that describes this migration, experiments must be conducted to evaluate the various functions. The authors expound on the design of the experiments planned. Basically, bench-scale experiments to be conducted on geologic salt cores are designed to study the influence of stress fields around salt cores as well as temperature and temperature-gradient effects. 
Hull, A.B., and M.G. Seitz (1985), An Integrated Approach to Determining Site Specific Brine Migration Parameters, Proc. U.S. Department of Energy Salt Repository Project Workshop on Brine Migration, Berkeley, Calif., April 17-19, in press, 9 pp.

The two most important issues to address in planning a nuclear waste repository in salt are fluid release rates and fluid composition. Hull and Seitz suggest an integrated approach comprising laboratory, field, and modeling studies to investigate these topics.

To determine hydraulic permeability, core samples about $9 \mathrm{~cm}$ long (collected from the McNutt evaporite at the WIPP site) were held at a pressure of $14 \mathrm{MPa}$ while a tritiated brine solution was added to the top of each core. The cores were observed at time intervals of $31,61,103$, and $137 \mathrm{~d}$. The results showed that the solution did not permeate the core uniformly. The measured hydraulic permeability was nil $\left(10^{-20} \mathrm{~m}^{2}\right)$. This test should help to screen repository sites for brine release rate.

In situ testing is necessary because the chemistry of rock salt and brine systems varies greatly from location to location. However, water, mineral, and impurity analyses can be conducted in the laboratory at low cost on salt blocks carefully retrieved from candidate repository sites. The analytical results can be used in computer models such as EQ3/6 and RADIOL to predict various parameters produced by irradiation of that particular salt. The information provided by these laboratory tests and compiter modeling methods can augment in situ testing by reducing costs and minimizing the time needed for site characterization.

Jenks, G.H. (1979), Effects of Temperature, Temperature Gradients, Stress, and Irradiation on Migration of Brine Inclusions in a Salt Repository, Oak Ridge National Laboratory Report ORNL-5526, 67 pp.

Salt samples were examined from Lyons and Hutchinson, Kansas (locale of Project Salt Vault), for the migration of fluid inclusions at $250^{\circ} \mathrm{C}$. The crystal sizes $(\sim 0.3-3 \mathrm{~cm}$ ) and inclusion sizes (generally in droplets $>0.5 \mathrm{~mm}$ ) examined were similar to those found in WIPP cores of rock salt. Chemical analyses of encapsulated brine indicated concentrations of $2.10 \underline{\mathrm{M} \mathrm{MgCl}} 2, \sim 1.9 \underline{\mathrm{M} \mathrm{NaCl} \text {, and }}$ measurable but unreported levels of $\mathrm{Ca}, \mathrm{Br}, \mathrm{SO}_{4}{ }^{2-}$, and $\mathrm{K}$.

The maximum brine migration rate can be written as the empirical expression:

$\log V / G_{s}=0.00656 \mathrm{~T}-0.6036$

where $T$ is the temperature of salt $\left({ }^{\circ} \mathrm{C}\right)$, and $V / G_{S}$ is the brine migration rate $\left(\mathrm{cm}^{2} / \mathrm{yr} \cdot{ }^{\circ} \mathrm{C}\right)$. Uncertainty in rates is caused by the retarding effects of grain boundaries in polycrystalline salt typical of bedded salt deposits. Using the above equation and assuming that the salt contained 0.5 vol. $\%$ brine inclusions, Jenks found that the results of brine inflow estimates for 10-year-old high-level 
radioactive wastes emplaced at $150 \mathrm{~kW} /$ acre indicated inflow rates starting at $0.7 \mathrm{~L} / \mathrm{yr}$ and totaling $12 \mathrm{~L}$ at $30 \mathrm{yr}$ after emplacement.

The role of stress in increasing $\mathrm{NaCl}$ solubility was considered both experimentally and theoretically. Jenks postulated that the maximum solubility increase $(-10 \%)$ will occur when the solid salt is stressed to a much greater extent than the accompanying solution, as would be the case in a flooded salt repository. Salt subjected to a stress gradient, or under conditions of equal pressure on the solution and salt, will have a less than $3 \%$ increase in solubility, which will be maximial at high pressure (i.e., $100 \mathrm{MPa}$ ) and low temperature (i.e., $25^{\circ} \mathrm{C}$ ). Brief mention is made that stored $\gamma$-ray energy could influence the solubility of salt. No experimental tests were done.

Jenks, G.H., and H.C. Claiborne (1981), Brine Migration in Salt and Its Implications in the Geologic Disposal of Nuclear Waste, Oak Ridge National Laboratory Report ORNL-5818, 164 pp.

This report comprehensively reviews and analyzes information collected by many researchers during the $15 \mathrm{yr}$ in which brine migration in salt has been extensively studied. In situ experiments of long duration are recommended to examine aspects of brine migration and behavior within nuclear waste emplacement cavities.

The report emphasizes those characteristics of salt formations and waste packages germane to considering rates, amounts, and effects of brine migration; experimental and theoretical information on brine migration; and design strategies to minimize the adverse effects of such migration. Most information on bedded salt summarized in the report concerns the Salado salt in southeastern New Mexico at depths projected for the WIPP repository, that is, at about $600 \mathrm{~m}$ and at $800-830 \mathrm{~m}$ below the surface. The authors did not examine the effects of hydrous minerals. Baseline repository characteristics considered in this report are a maximum temperature gradient of about $1.6^{\circ} \mathrm{C} / \mathrm{cm}$, maximum temperatures $15 \mathrm{yr}$ after waste emplacement of about $210^{\circ} \mathrm{C}$ with $37 \mathrm{~W} / \mathrm{m}^{2}$ loading and about $155^{\circ} \mathrm{C}$ with $25 \mathrm{~W} / \mathrm{m}^{2}$ loading. Results from the MIGRAIN computer code indicate that $180 \mathrm{~mL} / \mathrm{yr}$ of brine will migrate to each reference package of waste emplaced. This brine is derived from about $24 \mathrm{~m}^{3}$ of salt given a thermal loading of $25 \mathrm{~W} / \mathrm{m}^{2}$. Although this result is based on the equation given in the abstract for Jenks (1979), MIGRAIN can use any equation that represents the velocity of brine migration as a function of temperature and temperature gradient. Tha results from other researchers are sum marized individually.

Krause, W.B. (1983), Avery Island Brine Migration Tests: Installation, Operation, Data Collection, Analysis, Office of Nuclear Waste Isolation Report ONW1-190(4), Battelle Memorial Institute, Columbus, Ohio, 91 pp.

The migration of brine inclusions surrounding a heater borehole was studied on a macroscopic level by investigating gross influences of thermal and stress 
conditions and on a microscopic level by analyzing changes in inclusion shape and movement of deuterated synthetic brine along grain boundaries.

Data are presented for brine migration tests in domal salt at the Avery Island salt mine near New Iberia, Louisiana. This salt consists of halite crystals averaging about $0.75 \mathrm{~cm}$ in diameter, with about $10 \mathrm{vol}$. \% anhydrite. Its effective moisture content is approximately $0.054 \mathrm{wt}$. \%. The few fluid inclusions present were evident in small fields consisting of several hundred square to rectangular inclusions occurring in cracks or along cleavage planes. The shortest inclusion dimension measured about $5 \mu \mathrm{m}$.

Tests were conducted to investigate three processes:

1. Natural brine movement under ambient temperature conditions.

2. Natural brine movement under elevated temperature conditions. (After 325 days, $5 \mathrm{gm}$ of fluid coalesced.)

3. Deuterium-tagged synthetic brine movement under elevated temperature conditions. (After $\mathbf{3 5 0}$ days, $8 \mathrm{gm}$ of fluid coalesced.)

In tests 2 and 3 , the maximum temperature was $51^{\circ} \mathrm{C}$, with $a 1.2^{\circ} \mathrm{C} / \mathrm{cm}$ temperature gradient. No radiation effects were studied. The permeability of salt decreased by four orders of magnitude during experimental runs under pressures up to $690 \mathrm{kPa}$. Moisture collection data are reported in grams of water per day. The magnitudes would mean more if expressed relative to the mass of the salt in the experiments. The cooling of the salt causes changes in tangential stresses, which leads to microcracking and opening of grain boundaries. Much moisture is released as a result of this process.

Lambert, S.J. (1980), Mineralogical Aspects of Fluid Migration in the Salt Block II Experiment, Sandia National Laboratories Report SAND 79-2423, 24 pp.

The Salt Block II experiment was a heating experiment conducted on a 2-t block of salt from the Delaware Basin. Its size (1-m diameter and height) was suitable for modeling the effects of heating a stratified evaporite. (Past experiments had used hand samples that were too small to represent the mineralogical variation.) Salt Block II, which contained $88 \%$ halite, $8 \%$ polyhalite, and $4 \%$ sylvite, was heated for $100 \mathrm{~d}$ with an axial heater while gas and liquid migration was monitored. A total of $111 \mathrm{~g}$ of water was given off while the rock was heated between $100^{\circ} \mathrm{C}$ and $200^{\circ} \mathrm{C}$, with a temperature gradient of $3-15^{\circ} \mathrm{C} / \mathrm{cm}$. The rock contained $8500 \mathrm{~g}$ water, so a relatively small portion was mobilized.

Petrographic and fluid inclusion studies on the heated salt block demonstrated that the block was most conspicuously affected by the temperature increase within $15 \mathrm{~cm}$ of the heat source. There was evidence of fluid inclusion migration, but rarely across grain boundaries. The presence of subsurface 
encrustations of carnallite $\left(\mathrm{KMgCl}_{3} \cdot 6 \mathrm{H}_{2} \mathrm{O}\right)$, bischofite $\left(\mathrm{MgCl}_{2} \cdot 6 \mathrm{H}_{2} \mathrm{O}\right)$, and recrystallized polyhalite $\left(\mathrm{K}_{2} \mathrm{Ca} 2 \mathrm{Mg}\left(\mathrm{SO}_{4}\right)_{4} \cdot 2 \mathrm{H}_{2} \mathrm{O}\right)$ indicates the chemistry of the water as it was expelled from the block, and leads Lambert to conclude that intergranular fluid was the source of the $111 \mathrm{~g}$ water driven off.

Olander, D.R. (1984), A Study of Thermal-Gradient-Induced Migration of Brine Inclusions in Salt: Final Report, Office of Nuclear Waste Isolation Report BMI/ONWI-538, Battelle Memorial Institute, Columbus, Ohio, 125 pp.

Thermal-gradient-driven brine migration was studied in rock salt from the Richton Dome and also in synthetic single crystals of $\mathrm{NaCl}$ and $\mathrm{KCl}$. By using a hot-stage attachment to an optical microscope, temperature gradients and axial compressive loads were imposed on these crystals.

Both all-liquid inclusions (ranging in size from micrometers to millimeters and occupying about 0.2 to somewhat more than 3.0 vol. $\%$ in bedded salt) filled with mixed brines and gas-liquid inclusions (incorporating $\mathrm{H}_{2} \mathrm{O}, \mathrm{CO}_{2}, \mathrm{CH}_{4}, \mathrm{~N}_{2}, \mathrm{H}_{2} \mathrm{~S}$, $\mathrm{He}, \mathrm{Ar}$, and air) responded to the temperature gradient. The minimum temperature gradient necessary for migration was about $10^{\circ} \mathrm{C} / \mathrm{cm}$. All-liquid inclusions migrate toward a heat source such as a radioactive waste canister, where they are transformed into gas-liquid inclusions, which return down the temperature gradient, thereby providing a means of dispersing radionuclides away from the initial emplacement site.

Impurities in rock salt retard migration by increasing the requisite minimum temperature gradient. Temperature, inclusion shape and size, and salt composition are very important parameters in stability analyses. By combining heat and mass transport phenomena in the solid-liquid-vapor phase system, the velocity of migration of gas-liguid inclusions can be calculated. Calculations approximate results from experimental data. The velocity of migration for gasliquid inclusions is $8-32 \mu \mathrm{m} / \mathrm{h}$ at $60^{\circ} \mathrm{C}, \Delta \mathrm{T}=25^{\circ} \mathrm{C} / \mathrm{cm}$, and an inclusion size of 9 $\mu \mathrm{m} \times 36 \mu \mathrm{m}$. Emphasis is placed on interfacial kinetics as a control that reduces the migration speeds far lower than the diffusion control limits.

Olander, D.R., A.J. Machiels, and E. Muchowski (1981), Migration of Gas-Liquid Inclusions in Single Crystals of Potassium and Sodium Chlorides, Nuclear Science and Engineering, 79:212-227.

A two-phase inclusion forms when an all-liquid inclusion reaches the waste package. As the inclusion opens up at the salt-package interface, the brine partially evaporates and the inclusion reseals with some insoluble gas trapped inside. Cavities that are filled partly with liquid and partly with an insoluble gas move down the temperature gradient away from the waste package, thus providing a pathway along which radionuclides leached from the waste form by the brine can be transported to the biosphere. 
The velocities of these gas-liquid inclusions are calculated from a model that includes (1) heat transport in the gas-liquid-solid composite medium, (2) vapor transport of water in the gas bubble, and (3) molecular and thermal diffusion of salt in the liquid phase as the principal mechanisms causing cavity motion. The theory predicts a change in the migration direction when fluid inclusions contain greater than $15 \%$ gas. The analytical expression developed for the inclusion velocity in $\mathrm{NaCl}$ gives the velocities of migration down the temperature gradient (away from the heat source), which agree with experimental data.

Pigford, T.H. (1982), Migration of Brine Inclusions in Salt, Nuclear Technology, 56:93101.

Theories of the migration of brine inclusions in salt proposed by Geguzin and Dzyuba (1975)* and Anthony and Cline (1971) are shown to be essentially identical for all-liquid inclusions. Their work was extended to calculate threshold temperature gradients below which brine migration ceases to occur at $25^{\circ} \mathrm{C}$. Brine migration across a fluid inclusion of thickness $L$ is shown schematically in Fig. 2. The concentration $\mathrm{C}_{\mathrm{se}}$ of salt in the "cold" liquid away

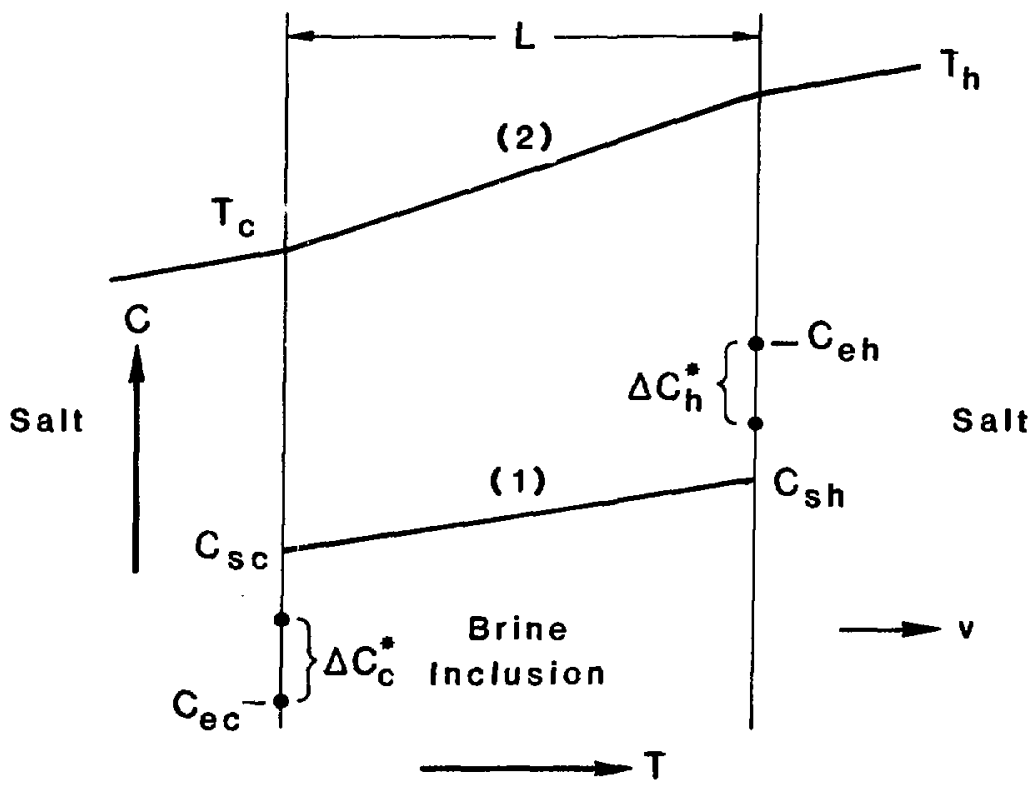

FIGURE 2 Concentration Profiles across a Fluid Inclusion in a

. Thermal Gradient (Source: Adapted from Pigford, 1982)

\footnotetext{
*Geguzin, Y.E., A.S. Dzyuba, and V.S. Kruzhanov (1975), Response to a Temperature Gradient from Liquid Inclusions in a Crystal, Soviet Physics -- Crystallography, 20:234238.
} 
from the heat source is greater than the saturation concentration $C_{e c}$ to nucleate crystallization at the cold side. Similarly, to promote dissolution, the concentration $\mathrm{C}_{\mathrm{sh}}$ of dissolved salt at the hot surface must be less than the saturation concentration $C_{e h}$. The parameters $\Delta C_{e}{ }^{*}$ and $\Delta C_{h}{ }^{*}$ are a critical concentration difference to nucleate a step on the orystalline surface or to effect surface distortion during dissolution. The sum of these two parameters, $\Delta C^{*}$, can be interpreted as a measure of the free energy that must be supplied to distort the inclusion surface so that dissolution and erystallization can occur. As concentration profiles (1) and (2) show, a simple diffusion mechanism can result in a linear change in concentration of the dissolved salt across the inclusion.

A brine inclusion that has reached a grain boundary is in a position of minimum energy, since the surface area of the grain boundary must be increased if the inclusion is moved from the boundary into an adjacent crystal. Thus, an inclusion migrating through a crystalline solid may either penetrate or be stopped by the grain boundary, depending on whether the force on the inclusion is sufficient to move the inclusion out of the energy well associated with the grain boundary. As is shown in Table 6, the grain boundary is the principal retarding force for small inclusions (less than $\sim 10^{-2} \mathrm{~cm}$ ), and the erystalline lattice is the principal retarding force for larger inclusions.

Temperature measurements in the Carlsbad salt at the WIPP site correspond to a geothermal gradient of $7.85 \times 10^{-5 \circ} \mathrm{C} / \mathrm{cm}$ and an average temperature of $28^{\circ} \mathrm{C}$. It can be calculated for a finite value of $\Delta C^{*}$ that all inclusions smaller than

TABLE 6 Threshold Temperature Gradients for No Migration

\begin{tabular}{|c|c|c|c|}
\hline \multirow{2}{*}{$\begin{array}{l}\text { Inclusion Size } \\
(\mathrm{cm})\end{array}$} & \multirow{2}{*}{$\begin{array}{c}\text { Intracrystalline } \mathrm{a}^{\mathrm{a}} \\
\nabla=\mathrm{T}_{\mathrm{s}} \min \\
\left({ }^{\circ} \mathrm{C} / \mathrm{cm}\right)\end{array}$} & \multicolumn{2}{|c|}{$\begin{array}{c}\text { Across Grain } \\
\text { Boundary }{ }^{\mathrm{b}} \nabla=\mathrm{T}_{\mathrm{s}}, \mathrm{min} \\
\left({ }^{\circ} \mathrm{C} / \mathrm{cm}\right)\end{array}$} \\
\hline & & $\Delta C^{*}>0$ & $\Delta C^{*}=0$ \\
\hline $5 \times 10^{-4}$ & 8.1 & 142 & 134 \\
\hline $1 \times 10^{-2}$ & 0.39 & 0.72 & 0.33 \\
\hline $2 \times 10^{-1}$ & 0.019 & 0.020 & $8.4 \times 10^{-4}$ \\
\hline
\end{tabular}

aThe threshold temperature below which the inclusions are not predicted to migrate within a crystal at $25^{\circ} \mathrm{C}$.

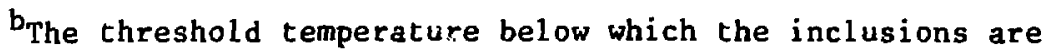
not predicted to cross a grain boundary at $25^{\circ} \mathrm{C}$. 
about $5 \mathrm{~cm}$ remain stationary within the crystalline lattice under the influence of the geothermal gradient. The presence of immobile brine inclusions in crystals of natural halite at the WIPP site, which has been under the influence of the geothermal gradient since their formation, further confirms the theory of a threshold temperature below which inclusions do not migrate.

Ratigan, J.L. (1984), A Sensitivity Study of Brine Transport into a Borehole Containing a Commercial High-Level Waste Canister, Nuclear Technology, 67:228-244.

Ratigan considers the stochastic problem of brine inflow into a CHLW borehole in an underground nuclear waste repository in salt. A sensitivity study using the finite-element method in concert with the Plackett-Burman method of experimenta! design indicated that the most significant parameter ranges contributing to the total range in brine inflow are the ratio of interconnected porosity to total porosity, the initial brine inclusion density, and the threshold temperature gradient. These input parameters are treated as stochastic Juantities to obtain the range in brine quantities that may come in contact with the waste package. Almost $85 \%$ of the range in total inflow at $100 \mathrm{yr}$ after emplacement can be attributed to these three parameters. This study indicates that reduction of uncertainty in the other five input parameters produces a very small reduction in the uncertainty in the calculation of total brine inflow to a CHLW borehole. These five parameters include matrix permeability, brine viscosity, crystal size and shape, matrix compressibility, and velocity of a brine inclusion as a function of temperature. For the minimum inflow case, the total inflow/axial length is greater than $2.5 \mathrm{~L} / \mathrm{m}$ after $100 \mathrm{yr}$. For the maximum inflow case, the value is greater than $400 \mathrm{~L} / \mathrm{m}$ after $100 \mathrm{yr}$.

There is no a priori guarantee that the Plackett-Burman method will be capable of identifying main effects in other applications. This method works only if there is no component of the system that contains interactions of two or more input parameters. If significant interaction exists between these stochastic input parameters, then a more exhaustive analysis is required.

Roedder, E., and I.M. Chou (1982), A Critique of "Brine Migration in Salt and Its Implications in the Geologic Disposal of Nuclear Waste," Oak Ridge National Laboratory Report 5818 by G.H. Jenks and H.C. Claiborne, U.S. Geological Survey Open-File Report 82-1131, $31 \mathrm{pp}$.

The basic thesis of this report is that Jenks and Claiborne (1981) seriously underestimated the rate and volume of brine expected to migrate into the emplacement hole in bedded salt during the first $100 \mathrm{yr}$. Their predicted $250-\mathrm{mL} / \mathrm{yr}$ brine migration rate may be two orders of magnitude too low. Roedder and Chou emphasize, however, that it is not possible to salculate the expected rate of inflow with any confidence because of the many variables. 
Their critique centers on disegreements with the nature and validity of assumptions in four key areas:

1. Water content to be used in calculations. They suggest that a more reasonable value for the "probable maximum amount of liquid water initially present" is not 0.5 vol. \%, but rather $1.7 \mathrm{wt}$. \%. But it must be noted that this value is still for intracrystalline liquid inclusions only and does not consider hydrous minerals (e.g., gypsum, polyhalite, clay partings, and potash zones) or in tergranular fluids.

2. Rate of migration of fluid inclusions through single-salt crystals. The experimental data (change in Soret coefficients of $\mathrm{NaCl}$ as a function of temperature) needed to verify the brine migration model of Anthony and Cline (1971) are not available, especially above $50^{\circ} \mathrm{C}$. For example, the solubility of halite as a function of time for complex brines needs to be measured.

3. Behavior of migrating fluid inclusions when they intersect grain boundaries.

4. Consideration of clays and hydrated saline minerals. Only very small fluid inclusions are stopped when they reach a grain boundary. Most brine is present as a few, very large inclusions that either leak into or cross grain boundaries. Much of the water in a salt bed occurs along halite grain boundaries, in intercrystalline fluid inclusions, and within hydrous minerals. Intragranular fluid, as distinguished from intergranular fluid, cannot move in response to a pressure gradient.

The "conservative" values for brine migration rates proposed by Jenks and Claiborne are considered several orders of magnitude too low for several reasons: (1) 0.19 wt. $\% \mathrm{H}_{2} \mathrm{O}$ for bedded salt was used instead of approximately 1.7 wt. $\% \mathrm{H}_{2} \mathrm{O}$; (2) a Soret coefficient of $0.004 /{ }^{\circ} \mathrm{C}$ between $50^{\circ}$ and $200^{\circ} \mathrm{C}$ was used, whereas the true value (no experimental determination presumed) may be higher than $0.01^{\circ} \mathrm{C}$; (3) a threshold value was assumed for the thermal gradient below which migration is assumed to cease; (4) rock salt formations of repository size were assumed to be isotropic and uniformly extremely low in permeability; (5) all water present was assumed to occur as intracrystalline inclusions; and (6) models for fluid migration through a polycrystalline, polymineralic rock salt mass and through a large single crystal of salt were assumed to be similar.

Sheíelbine, H.C. (1982), Brine Migration: A Summary Report, Sandia National Laboratories Report SAND-82-0152, 53 pp.

Results and environmental extrapolations are presented from experiments that examined salt from the Mississippi Chemical Corporation Mine (southeast of the New Mexico potash mine) and that focused on moisture release from macroscopic samples of polycrystalline salt. All experimental strategies examined the effect of heat alone. The contribution of hydrated minerals to the total water content 
was determined by thermogravimetric analysis. Crushed samples heated to high temperatures $\left(370^{\circ} \mathrm{C}\right)$ also yield these data. Polyhalite containing 6 wt. $\% \mathrm{H}_{2} \mathrm{O}$ was completely dehydrated above $220^{\circ} \mathrm{C}$. Calculations demonstrate that less than $20 \mathrm{~L}$ of brine per wuste canister can collect in $1000 \mathrm{yr}$ under worst-case conditions of $150 \mathrm{~kW} / \mathrm{acre}$ and $2.16 \mathrm{~kW} /$ canister. Only water closer than $60 \mathrm{~cm}$ actually reaches the canister. This projected fluid inflow is based on the assumptions that (1) the total available water content of the salt is about $0.3 \mathrm{wt}$. \%, (2) the emplacement holes do not intersect seams of other materials such as clays, and (3) the brine is derived exclusively from halite and thus behaves at elevated temperatures like a simple $\mathrm{NaCl}$ brine. Conclusions that were reached include: (1) $20 \mathrm{~L}$ of brine would not cause much movement of the waste canister, (2) the average corrosion depth would be less than $2 \mathrm{~mm}$ if all water present were consumed in oxidizing an iron canister, (3) complete radiolysis of water would not generate enough pressure to fracture salt, and (4) brine could not cause migration of radionuclides because it loses its identity as a liquid in either corrosion of the canister or interaction with the waste.

The advantages and disadvantages of the following proposed brine migration mechanisms were discussed:

1. Brine-inclusion motion (describing movement of intragranular inclusions in a temperature gradient).

2. Vapor-phase transport (vapor pressure of brine driving water flow through connected porosity in rock salt).

3. Stress-gradient transport (rock stress governing brine pore pressure).

Westinghouse Electric Company, Brine Migration Test for Asse Mine, Federal Republic of Germany, Final Test Plan (1983), Office of Nuclear Waste Isolation Report ONWI-242, Battelle Memorial Institute, Columbus, Ohio, 239 pp.

Proposed research at the Asse mine and expected results are described in this very comprehensive volume. Test results from this two-year experiment are expected to be published in the last half of the 1980s. The report details plans to evaluate the relative importance of liquid inclusion migration and vapor migration in both pure salt and transition salt containing a relatively large quantity of anhydrite and polyhalite. The transition salt is representative of many German repository environments. The pure salt is similar to U.S. domed salt; only the vapor migration theory (evaporation and flow of water vapor via porosity) can be tested on site because of few brine inclusion droplets. Brine migration in a CHLW repository is expected to collect most of the potential brine inflow at the borehole within a period of $50 \mathrm{yr}$.

The combined effects of brine, radiation, and heat on the rock salt will be studied under a dose rate of $3 \times 10^{8} \mathrm{rad} / \mathrm{yr}$, which is considered to be the maximum dose for $\mathrm{CHLW}$ repositories. The four types of water in rock salt and 
their roles in models of liquid inclusion migration and vapor migration are described in detail. These water sources include brine inclusion droplets, erystal boundary surface water (i.e., intergranular water), water of hydration in minerals such as gypsum, and water molecules trapped within the crystal lattice (hydrous minerals).

Yagnik, S.L. (1983), Thermal-Gradient Migration of Brine Inclusions in Salt Crystals, unpublished Ph.D. dissertation, Lawrence Berkeley National Laboratory, University of California, 123 pp.

Yagnik, working under the tutelage of Olander, studied the migration in a thermal gradient of both all-liquid and gas-liquid inclusions in synthetic single crystals of $\mathrm{NaCl}$ and $\mathrm{KCl}$. A hot-stage attachment to an optical microscope imposed temperature gradients and axial compressive loads on these crystals. For polycrystalline natural samples, the optical microseope method would have to be replaced by radioactive tagging strategies for following migration pathways.

Because an inclusion can be perceived as a "negative" crystal, the theoretical and mathematical foundations of crystal growth and dissolution theory can be exploited to understand the interfacial kinetics of a migrating all-liquid inclusion. Chemical impurities retard crystal and fluid inclusion growth through analogous mechanisms.

Fluid migration velocity varies approximately as the square of the temperature gradient, in accordance with the Burton-Caberra-Frank model, in which erystallization is catalyzed by thermally induced dislocations emerging at the interface. Diffusion control is expected for inclusions large enough to be intersected by a large number of defects. The rate-limiting process in the migration of fluid inclusions in a thermal gradient depends on the size of the inclusion and the dislocation density of the salt. In the migration of gas-liquid inclusions, the migration velocity decreases as the gas density increases. 


\section{BEHAVIOR OF RADIONUCLIDES}

Elders, W.A., and J.B. Moody (1985), The Salton Sea Geothermal Field as a Natural Analog for the Near-Field in a High-Level Nuclear Waste Repository, in Seientific Basis for Nuclear Waste Management VIII, C.M. Jantzen et al., eds., Materials Researuh Society, Pittsburgh, pp. 565-572.

The Salton Sea geothermal field has been chosen as a natural analog of the nearfield environment around a nuclear waste repository in salt. The reasons for choosing this geothermal field are: (1) it is well understood and under commercial development, (2) fluid temperatures extend up to $300^{\circ} \mathrm{C}$, (3) fluid salinities are similar to those expected in a repository $(4,000-250,000 \mathrm{ppm}$ TDS), (4) the sedimentary section is analogous to typical host rocks for a repository in salt, and (5) the system has been active for more than $25,000 \mathrm{yr}$.

This paper investigates the chemistry of the Salton Sea brines, which are enriched in $\mathrm{Na}, \mathrm{Mn}, \mathrm{Zn}, \mathrm{Sr}, \mathrm{Ra}$, and Po; depleted in $\mathrm{Ba}, \mathrm{Si}, \mathrm{Mg}, \mathrm{Ti}$, and $\mathrm{Al}$; and strongly depleted in $U$ and $T h$. Observations suggest that $U$ and $T h$ are relatively immobile in these hot brines, while $\mathrm{Ra}, \mathrm{Po}, \mathrm{Cs}$, and $\mathrm{Sr}$ are mobile.

Kerrisk, J.F. (1985), Solubility Limits on Radionuclide Dissolution, in Scientific Basis for Nuclear Waste Management VIII, C.M. Jantzen et al., eds., Materials Research Society, Pittsburgh, pp. 237-244.

Kerrisk delineates the effects of solubility in limiting dissolution rates of radionuclides from high-level radioactive waste. Data characteristic of a Yucca Mountain repository were used in mathematical models to evaluate dissolution in both a saturation-limited and diffusion-limited situation.

Calculations were based on solubilities derived from the computer code EQ3/6 and projected dissolution for times of $100,1,000,10,000$, and $100,000 \mathrm{yr}$ after emplacement. The results showed that, where oxidizing conditions were assumed, solubility limits dissolution rates of $\mathrm{Pu}, \mathrm{Am}, \mathrm{Sn}, \mathrm{Th}, \mathrm{Zr}$, and $\mathrm{Sm}$, and sometimes $\mathrm{U}, \mathrm{Cm}, \mathrm{Ni}$, and $\mathrm{Ra}$. The diffusion-limited model is thought to be more realistic for simulating repository conditions because dissolution rates of trace elements are limited by diffusion into water flowing past the waste. The dissolution rates of $\mathrm{Cs}, \mathrm{Tc}, \mathrm{Np}, \mathrm{Sr}, \mathrm{C}$, and I are always limited by dissolution of the bulk waste forms.

Moody, J.B. (1982), Radionuclide Migration/Retardation Research and Development Technology Status Report, Office of Nuclear Waste Isolation Report ONWI-321, Battelle Memorial Institute, Columbus, Ohio, $71 \mathrm{pp}$.

The strengths and weaknesses of the research done to date on radionuclide migration and retardation are presented. Integrated laboratory, field, and 
modeling studies, ineluding the use of natural analogs, need to be conducted so that radioactive retardation or migration from a mined geologic repository can be predicted. Accurate understanding of radionuclide migration requires a geochemical model that simultaneously considers speciation, solubility, and sorption phenomena. Models must deal with temperatures up to $350^{\circ} \mathrm{C}$, pressures up to $100 \mathrm{MPa}$, high-ionic-strength environments, solid-solution interfaces, and reaction-rate effects.

Future research should emphasize a systems approach in which each of the components of the multibarrier system, the interaction among these components, and the action of the system as a whole are considered. One example of the importance of a systems approach to simulating the near-field and far-field environments is the discovery that ethylene diamine tetraacetic acid, a complexing agent commonly used in decontamination operations at nuclear facilities, forms a strong complex with $\mathrm{Pu}, \mathrm{Am}, \mathrm{Cu}, \mathrm{Th}$, and $\mathrm{Co}$. These reactions will increase the potential of migration of radionuclides from burial sites. Chemical additions must not worsen storage problems; a simulated systems analysis may help recognition of such situations.

Twelve tables and four figures summarize the pertinent information about basic geochemical parameters, such as the important radionuclide properties and factors affecting migration retardation.

Myers, J., G. Ulmer, D. Grandstaff, R. Brozdowski, M. Danielson, and O. Koski (1984), Development in the Monitoring and Control of Eh and $\mathrm{pH}$ Conditions in Hydrothermal Experiments, in Geochemical Behavior of Disposed Radioactive Wastes, G. Barney et al., eds., ACS Symposium Series 246, American Chemical Society, Washington, D.C., pp. 197216.

Solubilities of such elements as Se, Pd, and Sn are strongly dependent on Eh and the ability of the natural environment to bring about oxidation or reduction. Because the solubilities of Se and Pd may reach very high levels under some Eh conditions, experimental studies should include $\mathrm{Eh}$ as a variable as well as temperature and $\mathrm{pH}$. Although the $\mathrm{Eh}$ and $\mathrm{pH}$ of a solution at elevated temperature and pressure can be inferred from chemical analysis at $25^{\circ} \mathrm{C}$ and 0.1 $\mathrm{MPa}$, these calculations are based on somewhat uncertain thermodynamic data.

Teflon ${ }^{\circledR}$-based $\mathrm{H}$ diffusion membrane Eh sensors and zirconia $\mathrm{pH}$ sensors that can withstand temperatures up to $300^{\circ} \mathrm{C}$ and pressures up to $30 \mathrm{MPa}$ are being developed by Rockwell Hanford Operations. Although still in the testing stages, sensors incorporated into autoclaves capable of measuring Eh-pH conditions at elevated pressures and temperatures are near usefulness. These sensors are geared to continuous monitoring of the $\mathrm{Eh}$ and $\mathrm{pH}$ of solutions during hydrothermal interaction tests between waste form, barrier material, and groundwater. Figures summarize the design and testing response of sensors. 
Silva, R.J., and H. Nitsche (1984), Thermodynamic Properties of Chemical Species of Waste Radionuclides, Proc. Nuclear Waste Geochemistry '83, D.H. Alexander and G.F. Birchard, eds., U.S. Nuclear Regulatory Commission, NUREG/CP-0052, pp. 70-93.

Solubility constraints control the maximum concentration of many radionuclides in backfill and in the very near field repository environment. Above the solubility limit, a radionuclide precipitate begins to form. To realistically model the projected amounts and rates of waste radionuclides released from underground facilities, all major compounds and solution complexes, together with reliable thermodynamic data on their solubilities and complexation, need to be included in the data base.

Oxide and hydrous oxide solid phases usually provide the solubility control for most of the radionuclides. The predominant soluble species for the radionuclides are neutral or anionic hydroxide-carbonate complexes. Both the solubility of $\mathrm{Am}(\mathrm{OH})_{3}$ in $0.1 \mathrm{M} \mathrm{NaClO}_{4}$ at $25^{\circ} \mathrm{C}, 0.1 \mathrm{MPa}$, and $\mathrm{pH} 6.12$, and the hydrolysis and carbonate complexation of $\mathrm{Am}^{3+}$, as representative of actinides in the trivalent state, were experimentally evaluated. The log of the solubility product quotient for the reaction:

$\mathrm{AmOHCO}_{3}(\mathrm{~s})+2 \mathrm{H}^{+}=\mathrm{Am}^{3+}+\mathrm{HCO}_{3}^{-}+\mathrm{H}_{2} \mathrm{O}$

was calculated as being $2.74 \pm 0.17$.

Graphs summarizing speciation calculations were made using the computer program MINEQL and defined experimental variables, including a temperature of $25^{\circ} \mathrm{C}$, a pH range from 6 to 10 , an ionic strength of $0.1 \mathrm{M}$, and $\mathrm{CO}_{3}{ }^{2-}$ concentrations up to $2 \times 10^{-3} \mathrm{M}$. Graphs of soluble Am species plotted against $\mathrm{pH}$ for different $\mathrm{CO}_{2} / \mathrm{CO}_{3}{ }^{2-}$ concentrations illustrate that the solubility of Am compounds is lowered as $\mathrm{CO}_{3}{ }^{2-}$ increases. Only the solid phases $\mathrm{Am}\left(\mathrm{OH}_{3}\right)$ and $\mathrm{AmOHCO}_{3}$ in the presence of $\mathrm{CO}_{3}{ }^{2-}$ appear to decrease the solubility of Am compounds. Procedures for synthesizing pure, crystalline neodymium carbonate $\left(\mathrm{NdOHCO}_{3}\right)$ and americium carbonate $\left(\mathrm{AmOHCO}_{3}\right)$ were extensively discussed.

Wollenberg, H., D. Brookins, L. Cohen, S. Flexser, M. Abashian, M. Murphy, and A. Williams (1984), Uranium, Thorium, and Trace Elements in Geologic Occurrences as Analogues of Nuclear Waste Repository Conditions, Proc. Nuclear Waste Geochemistry '83, D.H. Alexander and G.F. Birchard, eds., U.S. Nuclear Regulatory Commission Report NUREG/CP-0052, pp. 464-491.

The contact zones between radioactive intrusive rocks and the surrounding country rocks were examined to study the alteration mineralogy and behavior of radioelements in conditions analogous to those in the near field of a nuclear waste repository. Although most of the analog investigations summarized focus 
on crystalline, tuffaceous, and basaltic rocks, the salt-based potential analog occurrences mentioned include:

1. A lamprophyre dike cutting the evaporite sequence of the Delaware Basin in southeastern New Mexico.

2. A basaltic dike transecting salt of the Zechstein Basin underlying northern West Germany.

3. Permian kimberlitic dikes cutting Upper Silurian salt beds of the Salina Basin in northwestern New York.

In all three cases, no migration of $U$ and Th radioelements from the intrusive dikes into the host rocks was detected. The dikes averaged about $2 \mathrm{ppm} U$ and greater than $8 \mathrm{ppm}$ Th. Chemical stability persisted despite a maximum postulated near-field temperature of greater than $300^{\circ} \mathrm{C}$ and for more than 10 million years after emplacement. 


\section{REPOSTTORY-SPECIFIC ENVIRONMENTS}

\subsection{GENERIC SALT REPOSITORIES}

Baes, C.F., L.O. Gilpatrick, F.G. Kitts, H.R. Bronstein, and A.J. Shor (1983), The Effect of Water in Salt Repositories: Final Report, Oak Ridge National Laboratory Report ORNL-5950, 62 pp.

Final results are presented of an experimental program in which the consolidation and permeability of polycrystalline salt in brine were studied as a function of time, applied stress, initial crystal size, and temperature. Although not a chemical investigation per se, the results have chemical implications. Blocks of halite were placed in hydraulic pressure cells, and the consolidation response was studied as a function of temperature from $20^{\circ} \mathrm{C}$ to $85^{\circ} \mathrm{C}$. Consolidation was slightly faster with increasing temperature. Uncier stress, polycrystalline salt consolidates readily in the presence of brine, with fairly predictable kinetics and expulsion of nearly all brine. The presence of clay accelerates the consolidation process by providing a lubricating action, which facilitates crystal reorientation but does not affect the permeability-void fraction relationship.

Results, representative of the kinetics of salt consoliojation to void fractions as low as $\mathbf{0 . 0 3}$, can be expressed as:

$\varphi(t)=\phi(0)-\left(P_{1} / P_{2}\right) \ln \left[1+P_{2} t / Z(0)^{3}\right]$

where:

$$
\begin{aligned}
\phi(t) & =\text { void fraction at time } t, \\
Z(0) & =\text { initial particle size, and } \\
P_{1} \text { and } P_{2} & =\text { constants for a given temperature and pressure. }
\end{aligned}
$$

The permeability decreased as the sixth power of the decreasing void fraction during consolidation according to:

$\ln \left[\mathrm{Pm} / 2(0)^{2}\right] \simeq 21+6 \ln \Phi(t)$

Here, permeability, $\mathrm{Pm}$, is defined as the brine flow through an area of $1 \mathrm{~cm}^{2}$ under a hydrostatic pressure gradient of $0.1 \mathrm{MPa} / \mathrm{cm}$ (units of permeability are thus $\mathrm{g} / \mathrm{cm}^{2} \cdot \mathrm{min} \cdot \mathrm{MPa}$ ). The flow of brine within specimens was influenced more by the consolidation of the specimen than by the temperature gradient. 
Clark, D.E., and D.J. Bradley (1983), Definition of the Waste Package Environment for a Repository Located in Salt, Proc. Civilian Radioactive Waste Management Information Meeting, Dec. 12-15, 1983, Washington, D.C., pp. 285-290.

The very near field parameters (those within approximately $2 \mathrm{~m}$ ) that will affect performance of the waste package are reviewed, including the composition and quantities of brines that may contact the waste packages, the composition of the host rock, redox conditions in the repository, and stress states in the host rock around the waste packages. The behavior of these site-specific parameters will be governed by the temperature and radiation fields. Computed temperature and radiation profiles for CHLW emplaced in a candidate salt repository site (Gibson Dome, Utak) are shown in Figs. 3 and 4.

The two principal scenarios used in discussing the possibilities of brines coming into contact with the waste package are based on human disruption and migration of preexisting fluids within the salt. The resultant brines, referred to here as intrusion brine and inclusion brine, respectively, are chemically and volumetrically quite different. Intrusion brines tend to be predominantly $\mathrm{NaCl}-$ saturated solutions with lesser amounts of other constituents of the host rock. The inclusion brine is notably higher in $\mathrm{K}^{+}, \mathrm{Mg}^{2+}$, and $\mathrm{Ca}^{2+}$. Retrograde solubilities of $\mathrm{CaSO}_{4}$ and $\mathrm{MgSO}_{4}$ can cause significant temperature-dependent

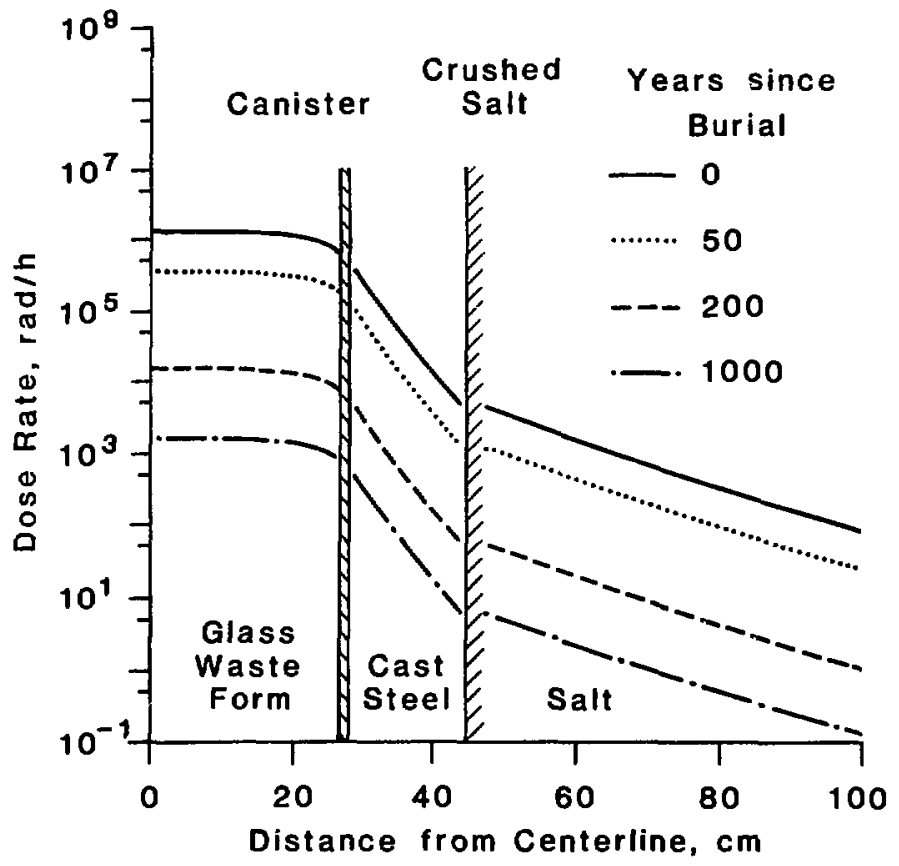

FIGURE 3 Temperature Profiles after Emplacement of CHLW in a Domal Salt Repository (Source: Adapted from Clark and Bradley, 1983) 


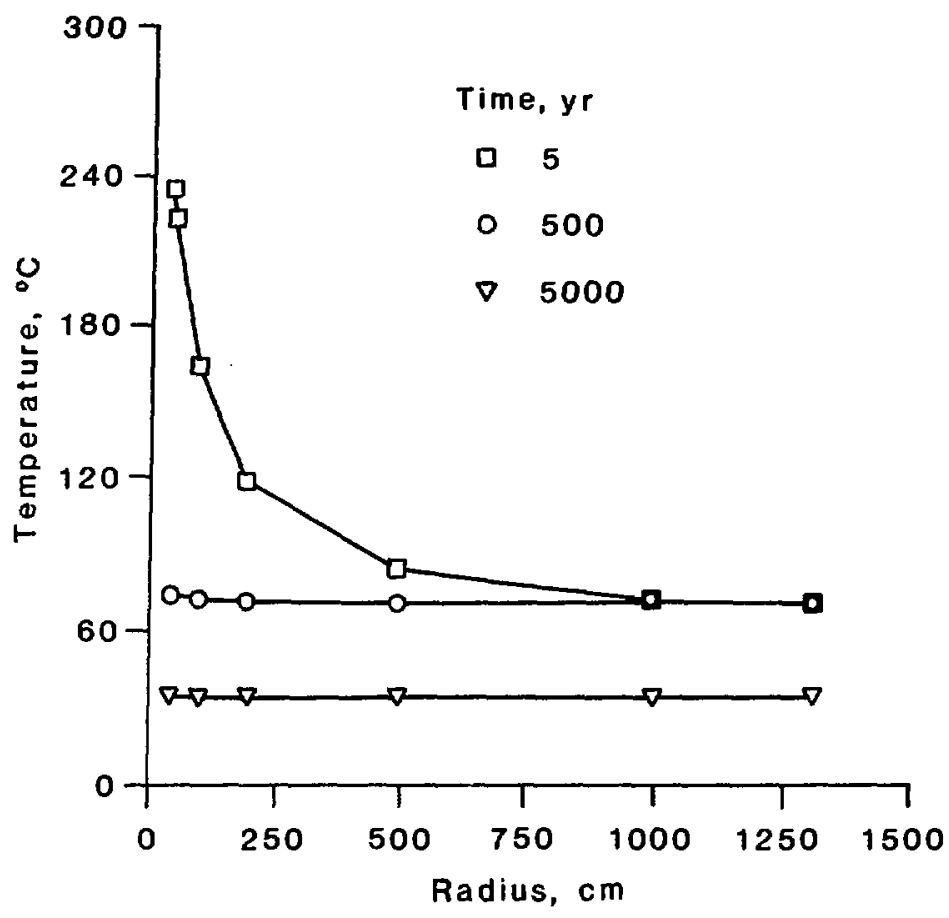

FIGURE 4 Radiation Profiles after Emplacement of CHLW in a Domal Salt Repository (Source: Adapted from Clark and Bradley, 1983)

changes in brine chemistry. Radiation-induced changes in salt are tied in to the fate of chlorine gas. Upon dissolution of $\gamma$-irradiated salt in water, the chlorine that has not escaped from the salt crystals will initially yield $\mathrm{HClO}$ plus $\mathrm{HCl}$. These products will essentially neutralize each other, leaving the $\mathrm{pH}$ controlled by the salt of a weak acid. This hypochlorite ion, disproportionating to chlorate ions and finally to perchlorate ions, controls the $\mathrm{pH}$ to a neutral level. Alpharadiolysis, occurring after the repository is breached and actinides have contaminated the surrounding fluid, creates a more oxidizing brine.

Elders, W.A., and L.H. Cohen (1983), The Salton Sea Geothermal Field, California, as a Near-Field Natural Analog of a Radioactive Waste Repository in Salt, prepared for Office of Nuclear Waste Isolation Report BMI/ONWI-513, Battelle Memorial Institute, Columbus, Ohio, 155 pp.

Analysis of geothermal fields permits direct study of the migration of naturally occurring radioactive elements such as $\mathrm{U}, \mathrm{Th}, \mathrm{Ra}, \mathrm{Cs}$, and $\mathrm{Sr}$ in concentrated hot brines moving through clay-rich sedimentary rocks over a 100,000-yr period. Although halite is absent, the sedimentary stratigraphic sequence is otherwise similar to that found in bedded or domal salt areas. The subsurface brines in the 
Salton trough, which reach a temperature of $365^{\circ} \mathrm{C}$ at a depth of $2 \mathrm{~km}$, are primarily $\mathrm{Na}, \mathrm{K}$, and $\mathrm{Ca}$ chlorides with up to 25\% TDS. High concentrations of such metals as $\mathrm{Fe}, \mathrm{Mn}, \mathrm{Li}$, and $\mathrm{Pb}$ occur as metal sulfides and help create a chemical environment somewhat different from that expected to surround a waste repository in salt.

This report is essentially an assemblage of geological, geophysical, and geochemical data. Characterizations are given with little application of data to problems of radioactive waste isolation. Useful tables are presented on the detailed chemical compositions of Salton Sea brines.

Pederson, L.R., D.E. Clark, F.N. Hodges, G.L. McVay, and D. Rai (1984), The Expected Environment for Waste Packages in a Salt Repository, in Scientific Besis for Nuclear Waste Management VII, G.L. McVay, ed., Elsevier, New York, pp. 417-426.

The results from irradiating rock salt, synthetic brines, and mixtures of rock salt and brine, and then reacting previously irradiated rock salt with brine solutions are discussed. Environmental conditions in the very near field may affect waste package performance. Migration of brine fluid inclusions up a thermal gradient toward the canister will produce a brine that has a composition determined by origin, temperature, irradiation history, and contact with irradiated rock salt.

The role of mineral impurities such as $\mathrm{Br}^{-}, \mathrm{Ca}^{2+}$, and $\mathrm{SO}_{4}{ }^{2-}$ is vital in modifying the effect of $\gamma$ radiolysis on both brines and crystalline salt. Small changes in the brine $\mathrm{Br}^{-}$concentration can cause large changes in the equilibrium hydrogen/oxygen pressures. The bromine ion acts as a scavenger for the hydroxyl radical that otherwise backreacts with hydrogen gas. The presence of impurities can either stabilize or retard radic:ion-induced defects, yielding a wide range of $\mathrm{Na}$-colloid production rates for different rock salts.

Elevated experimental temperatures ranging from $150^{\circ} \mathrm{C}$ to $250^{\circ} \mathrm{C}$ had a significant effect on Permian Basin core composite brines. Retrograde solubilities of compounds such as anhydrite, gypsum, and calcite were observed to change brine chemistry. Changes in hydrolysis constants with increasing temperature caused changes in $\mathrm{pH}$.

The propensity of irradiated salts to liberate free chlorine (as deduced from the elevated $\mathrm{pH}$ values after crushing and annealing at temperatures up to $200^{\circ} \mathrm{C}$ ) appears to be a function of salt composition, crystal size, and annealing temperature. The greatest leach rates of the waste glasses occurred when air was present, allowing $\mathrm{HNO}_{3}$ to form, and under $\gamma$ radiolysis at about $50^{\circ} \mathrm{C}$. 
Shade, J.W. (1985), Current Generic Issues Related to Near-Field Materials Testing, in Scientific Basis for Nuclear Waste Management VIII, C.M. Jantzen et al., eds., Materials Research Society, Pittsburgh, pp. 775-781.

This paper briefly discusses unresolved issues that can adversely affect the results of waste package and waste form tests, and that should be resolved before acceptance criteria are established. These issues include $\mathrm{Eh} / \mathrm{pH}$ system effects, surface area/volume effects, temperature effects on sampling, waste package composition effects, colloid formation and stability, radiolysis, and formation kinetics and stability of secondary reaction products. Recommendations for studies to resolve these issues include:

1. Because Eh and $\mathrm{pH}$ are difficult to measure accurately under repository conditions, direct measurement of redox couples may be more reliable than electrode measurements for speciation determination. Special attention should be given to the effects of temperature on redox state and speciation.

2. Experimental results indicate that the ratio of surface area to volume of the waste form has a significant effect on low-temperature waste dissolution behavior (up to $150^{\circ} \mathrm{C}$ ). A greater surface area increases dissolution and $\mathrm{pH}$. More work is needed at higher temperatures.

3. The effects of waste package components on waste form dissolution have been determiiced for one-to-one waste-form:basalt ratios, but a more appropriate rock-to-waste ratio would be 20:1. More experimentation is needed before solubility and transport models can be evaluated.

4. Colloid formation can create a mechanism of transport for actinides not predicted by solubility calculations. More studies on colloids are needed.

5. Alpha recoil radiolysis may be of concern in the long term and should be studied along with near-term $\gamma$-radiolysis effects.

6. Secondary products are mostly metastable, and solubility calculations are only valid if reaction paths are known. Therefore, experimental thermodynamic and kinetic approaches should be tried to establish waste package reaction paths.

Uerpmann, P., and N. Jockwer (1982), Salt as a Host Rock for Radioactive Waste Disposal, in Geological Disposal of Radioactive Waste: Geochemical Processes, Organization for Economic Cooperation and Development, Nuclear Energy Agency, Paris, pp. 93-103.

The pros and cons of locating nuclear repositories in salt are summarized (see Table 7), and the most common evaporite minerals forming salt beds are discussed in this general primer and review. In the discussion on water content, 
TABLE 7 Advantages and Disadvantages of Using Salt Formations for Nuclear Repositories

\begin{tabular}{lc}
\hline \multicolumn{1}{c}{ Pros } & Cons \\
\hline $\begin{array}{c}\text { High plasticity, which encourages } \\
\text { annealing }\end{array}$ & $\begin{array}{c}\text { High plasticity coupled with low } \\
\text { density, which fosters salt } \\
\text { migration }\end{array}$ \\
$\begin{array}{c}\text { Isolation from water by cap rock } \\
\text { (often kainite) or clay }\end{array}$ & $\begin{array}{c}\text { Low sorptive capacity for radio- } \\
\text { nuclides }\end{array}$ \\
$\begin{array}{c}\text { Good heat conductivity } 5 \text { w/m. } \\
\left.\text { Very low permeability } 50^{\circ} \mathrm{C}\right)\end{array}$ & $\begin{array}{c}\text { Potential for corrosive brines } \\
\text { attacking waste canisters }\end{array}$ \\
Established mining technology & $\begin{array}{c}\text { Unpredictability associated with } \\
\text { physical inhomogeneity }\end{array}$ \\
& $\begin{array}{c}\text { Possibility of accidental mining } \\
\text { by future civilizations }\end{array}$
\end{tabular}

Source: Uerpmann and Jockwer, 1982.

emphasis is placed on the fact that $99 \%$ of water in rock salt is estimated to be water of hydration, which can be slowly released at low temperatures if the vapor pressure differences are sufficient. The implication is that more attention should be focused on this neglected brine source.

Permeability in rock salt is very low but is quite pressure sensitive. Laboratoryderived values for permeability range from $0.0005 \mu \mathrm{D}$ at atmospheric pressure to $3.4 \mu \mathrm{D}$ at $14 \mathrm{MPa}$ triaxial pressure. Open porosity varies from $0.01 \%$ to $0.09 \%$, with the specific surface area parameter varying from $0.005 \mathrm{~m}^{2} / \mathrm{g}$ to $0.07 \mathrm{~m}^{2} / \mathrm{g}$. Absorption of $\mathrm{Y}$ radiation is proportional to media density. Rock salt with a density of $2.2 \mathrm{~g} / \mathrm{cm}^{3}$ has an absorption coefficient of $0.187 / \mathrm{cm}$ when the median r-radiation energy is $0.7 \mathrm{MeV}$.

The solubilities of marine salt deposits are briefly presented, with the main interest being in the $\mathrm{NaCl}-\mathrm{H}_{2} \mathrm{O}$ system and in solutions saturated with halite, sylvite, carnallite, kainite, kieserite, and polyhalite. Observations of flooded salt mines indicate that thermal and chemical equilibria, characterized by halitesaturated brine with densities of approximately $1.3 \mathrm{~g} / \mathrm{cm}^{3}$, are established within three years. 


\subsection{WASTE ISOLATION PILOT PLANT SITE}

Anderson, R.Y. (1982), Deformation-Dissolution Potential of Bedded Salt, Waste Isolation Pilot Plant Site, Delaware Basin, New Mexico, in Scientific Basis ior Nuclear Waste Management V, W. Lutze, ed., Elsevier, New York, pp. 449-458.

The evidence for deep-seated salt dissolution and the relationship between deformation, dissolution, and brine are briefly discussed. The potential for dissolution at the WIPP site through the deformation-dissolution process is also examined. This process may be generic to bedded salt, with the extent of dissolution depending on the particular geologic setting.

The WIPP site is located in the Delaware Basin, which contains Upper Permian Castile and Salado evaporites. Because salt has been eroded away via an unknown dissolution process at nearby locations and in the horizon of the repository, the WIPP site must be considered an area predisposed to deep-seated dissolution.

Two distinctly different dissolution models have been postulated. The first suggests that a dramatic thermal event such as the intrusion of a basaltic dike ( 30-35 million years ago) may have caused regional fracturing, rock dissolution, and brine formation. The second proposes that water was derived from the basin aquifer beneath the deformed salt. Driven upwards by artesian pressure, the water reached the salt through fractures in the lower anhydrite bed. A feedback response resulted in additional anhydrite fracturing and further dissolution. Expanded dissolution was then linked with surface drainage in'o a regional front that resulted in deep-seated dissolution progressing eastward across the basin.

Both models stress that the availability of fracture networks determines the location and extent of salt deformation. Subsurface water transported through these networks can "soften" the salt to a point where the yield point is eliminated, which facilitates thermal convection at shallow depths. The resultant heat transfer reduces the effective viscosity of polycrystalline halite by three to nine orders of magnitude. Ductile flow and thermally induced gravity movement otherwise requires a burial depth of $5000-8000 \mathrm{~m}$.

Bowers, D.L., and M.G. Seitz (1981), A Simulated Groundwater Experiment for the Waste Isolation Pilot Plant (WIPP), in Analytical Chemistry in Nuclear Technology, W.S. Lyon, ed., Ann Arbor Science, Ann Arbor, Mich., pp. 335-343.

Results are presented from laboratory groundwater stream experiments simulating a hydraulic breach of a nuclear waste repository. Tritiated brine was used as a tracer to measure the diffusion of water through cores of rock salt from the Mississippi bed of the McNutt evaporite structure in New Mexico. The experimental temperature and pressure were $21^{\circ} \mathrm{C}$ and $14 \mathrm{MPa}$. 
Experimental data from liquid scintillation counting of tritium were fitted to Fick's first law of diffusion, resulting in a maximum concentration of water in the rock salt of $75 \mathrm{ppm}$, with a diffusion coeffjeient of $2.0 \times 10^{-7} \mathrm{~cm}^{2} / \mathrm{s}$. It was calculated that $0.04 \mathrm{\mu L}$ of water per square centimeter of core surface traversed the 8.89-cm-long rock cores over 140 days. On the basis of the strong and sustained gradient in the tritiated water concentration, there does not appear to be significant permeation of the water through the rock as a result of the imposed hydraulic gradient. With the limited fluid permeation that did occur, tritiated water was incorporated into the rock salt cores by hydration (with possible recrystallization) at the top core surface and by diffusion.

Brookins, D.G. (1982), Study of Polyhalite from the WIPP Site, New Mexico, in Scientific Basis for Nuclear Waste Management VI, S.V. Topp, ed., Elsevier, New York, pp. 257-264.

This paper helps to allay concern that the polyhalite, $\mathrm{K}_{2} \mathrm{Ca} 2 \mathrm{Mg}(\mathrm{SO})_{4} \cdot 2 \mathrm{H}_{2} \mathrm{O}$, found at the WIPP site might be a secondary mineral. Questions have been raised as to whether polyhalite (of ten mixed with halite, anhydrite, and other minerals in bedded salt formations) is a primary mineral that formed close to the time of sedimentation or that formed continuously through the Mesozoic and Cenozoic eras. Radioactive dating using $\mathrm{K}$-Ar indicates primary polyhalite formation during the late Permian period, about 240 million years ago. In previous experimental studies, the apparent age had been found to be much less than the actual age; that is, the polyhalite had appeared to be secondary when it is actually primary.

Extensive secondary polyhalite formation would have indicated the continuing presence of water in the postevaporite formation and would have created uncertainty about radioactive waste emplacement. In the WIPP region, some secondary polyhalite was formed about 34 million years ago from an igneous lamprophyre dike. Such recrystallization ef fects in intruded evaporites required a source of new water. The sources from which the water could have been derived include (1) an intruded dike, (2) clay minerals and hydroxides near the dike contact, (3) brine pockets, (4) fluid inclusions in contact zone evaporites, or (5) recrystallized hydrous minerals. The first two alternatives are the most plausible.

Unpublished free-energy-of-formation data (Brookins, 1982) indicate polyhalite to be stable relative to carnallite, sylvite, and anhydrite, unless large amounts of water and $\mathrm{Cl}^{-}$are present. The following, where $\mathrm{PH}=$ polyhalite, $\mathrm{HA}=$ halite, $\mathrm{SY}=$ sylvite, $\mathrm{AN}=$ anhydrite, $\mathrm{CM}=$ clay minerals, and $\mathrm{W}=$ water, are unbalanced reactions proposed for polyhalite stability relative to other minerals:

$$
\begin{aligned}
& \mathrm{PH}+\mathrm{HA}+\mathrm{W}=\mathrm{CM}+\mathrm{AN}+\mathrm{SY}+\mathrm{K}^{+}+\mathrm{SO}_{4}{ }^{2-} \\
& \mathrm{PH}+\mathrm{W}+\mathrm{Cl}^{-}=\mathrm{CM}+\mathrm{K}^{+}+\mathrm{Ca}^{2+}+\mathrm{SO}_{4}{ }^{2-}
\end{aligned}
$$




$$
\begin{aligned}
& \mathrm{PH}+\mathrm{W}+\mathrm{Mg}^{2+}+\mathrm{Cl}^{-}=\mathrm{CM}+\mathrm{Ca}^{2+}+\mathrm{SO}_{4}{ }^{2-} \\
& \mathrm{PH}+\mathrm{W}+\mathrm{Cl}^{-}=\mathrm{SY}+\mathrm{CM}+\mathrm{AN}+\mathrm{SO}_{4}{ }^{2-}
\end{aligned}
$$

Coons, W.E., D. Meyer, R.L. Olsen, and J.K. Register (1984), The Geochemistry of the Castile Brines: Implications for their Origin and Impact on the WIPP Site, in Scientific Basis for Nuclear Waste Management VII, G.L. MeVay, ed., Elsevier, New York, pp. 4958.

The origin and thermodynamic stability of the pressurized brine reservoir in the Castile anhydrite underlying the candidate repository horizon for WIPP were investigated by (1) ploting solute versus bromide, (2) examining the $\varepsilon^{18} \mathrm{O}$ and $\delta^{34} \mathrm{~S}$ signature of brines, (3) processing major and minor elements in brine using a Pitzer-type thermodynamic model and predicting which minerals were theoretically at saturation, and (4) attempting to model pathways through which the existing major and minor elemental profiles in brines could be generated by using minerals known to be in the basin.

The conclusions are that the reservoir waters were formed from the Permian Sea instead of from meteoric water or water of dehydration. At the current temperature, thermodynamic calculations indicate that the brines approach saturation with respect to all major minerals in the host horizon, implying that the brine is chemically stable. Brines cannot degrade the integrity of the WIPP site because brine volume expansion will be limited to the finite amount of pore water available through fractures.

Panel on the Waste Isolation Pilot Plant (1984), Review of the Scientific and Technical Criteria for the Waste Isolation Pilot Plant (WIPP), Board on Radioactive Waste Management, Commission on Physical Sciences, Mathematics, and Resources, National Research Council, National Academy Press, Washington, D.C., 130 pp.

Although-the important issues about the geology at the WIPP site have been resolved, the panel concludes that some issues remain concerning hydrology and design of the facility that should be resolved before large-scale emplacement of transuranic wastes begins. The pertinent criteria used to select the WIPP site were outlined, including a bed of halite at least $60 \mathrm{~m}$ thick of sufficient purity to minimize chemical complications from brines of complex composition and from water released f:om hydrous minerals, and a depth greater than $300 \mathrm{~m}$ and less than $1000 \mathrm{~m}$ to ensure freedom from surface influences and acceptably low creep rates.

The issue of gas generation is dealt with. The danger point of self-pressurization is when the lithostatic pressure at repository depth is approximately $15 \mathrm{MPa}$. The contributions from the four major gas-generating processes (radiolysis, thermal degradation, bacterial degradation, and chemical corrosion) were judged to be much lower than this. The panel emphasizes that the humidity of still air 
in equilibrium with the salt and the $\mathrm{pH}$ of moisture in contact with the salt at the storage horizon should be measured because they are significant for evaluating biological and chemical degradation processes. The in situ testing plan is summarized. Brine migration tests under thermal and $r$-radiation loading are scheduled for about 1987. A glossary is included, as are six appendixes.

Zand, S.M. (1982), Dissolution of Evaporites and Its Possible Impact on the Integrity of the Waste Isolation Pilot Plant (WIPP), New Mexico, USA, in Seientific Basis for Nuclear Waste Management V, W. Lutze, ed., Elsevier, New York, pp. 439-448.

Two opposing theories about deep dissolution are summarized in this article: (1) that dissolution is a real phenomena caused by a brine density flow mechanism driven by TDS concentration gradients in artesian groundwater and (2) that deep dissolution does not occur and that it is an artifact caused by surface dissolution of previously shallower evaporite beds. In the first theory, the thinning of halite beds is the apparent source for differential brine enrichment. The evidence for deep-seated dissolution includes land subsidence, brine reservoirs in the Delaware Basin, and breccia pipes. Actually, breccia pipes provide rather debatable evidence because they can also be perceived as analogous to pressure relief valves generated by the underlying regional undulatory thrust fault.

Both deep and shallow dissolution fronts could compound the hazards of nuclear waste repositories. Radionuclide flow af ter a liquid breach scenario could be accelerated by deep dissolution. If a radionuclide-rich brine moved through the Bell Canyon aquifer in southeastern New Mexico, it could take an estimated $600,000 \mathrm{yr}$ for negative environmental effects. A shallow dissolution front exists near the WIPP site. Driven by the effects of climatic precipitation and surface water on exposed evaporites, the shallow dissolution front movement towards the WIPP repository is vertically about $15 \mathrm{~cm} / 1000$ yr and horizontally about 13 $\mathrm{m} / 1000 \mathrm{yr}$. At this rate, it would take $3.25 \times 10^{6} \mathrm{yr}$ for the front to breach the repository. 


\section{FIRST AUTHOR INDEX}

Anderson, R.Y. (1982), Deformation-Dissolution Potential of Bedded Salt, Waste Isolation Pilot Plant Site, Delaware Basin, New Mexico, in Scientific Basis for Nuclear Waste Management V, W. Lutze, ed., Elsevier, New York, pp. 449-458 ..........................

Anthony, T.R., and H.E. Cline (1971), Thermal Migration of Liquid Droplets through Solids, Journal of Applied Physics, 4?:3380-3387 .

Baes, C.F., L.O. Gilpatrick, F.G. Kitts, H.R. Bronstein, and A.J. Shor (1983), The Effect of Water in Salt Repositories: Final Report, Oak Ridge National Laboratory Report ORNL-5950, 62 pp. . . . . . . . . . . . .

Biggers, J.V., and G.O. Dayton (1982), Brine Migration in Hot-Pressed Polycrystalline Sodium Chloride, Office of Nuclear Waste Isolation Report ONWI-415, Battelle Memorial Institute, Columbus, Ohio, 88 pp. ........................................

Bowers, D.L., and M.G. Seitz (1981), A Simulated Groundwater Experiment for the Waste Isolation Pilot Plant (WIPP), in Analytical Chemistry in Nuclear Technology, W.S. Lyon, ed., Ann Arbor Science, Ann Arbor, Mich., pp. 335-343 .................................

Braitsch, O. (1971), Salt Deposits: Their Origin and Composition, SpringerVerlag, Berlin, 297 pp. ...............................

Brookins, D.G. (1982), Study of Polyhalite from the WIPP Site, New Mexico, in Scientific Basis for Nuclear Waste Management VI, S.V. Topp, ed., Elsevier, New York, pp. 257-264..........................

Brookins, D.G. (1984), Geochemical Aspects of Radioactive Waste Disposal, Springer-Verlag, New York, 347 pp.........................

Burns, W.G., A.E. Hughes, J.A.C. Marples, R.S. Nelson, and A.M. Stoneham (1982), Radiation Effects and the Leach Rates of Vitrified Radioactive Waste, Nature, 295:130-132.

Chou, I.M. (1982), Migration Rates of Brine Inclusions in Single Crystals of $\mathrm{NaCl}$, in Scientific Basis for Nuclear Waste Management VI, S.V. Topp, ed., Elsevier, New York, pp. 303-310........................

Clark, D.E., and D.J. Bradley (1983), Definition of the Waste Package Environment for a Repository Located in Salt, Proc. Civilian Radioactive Waste Management Information Meeting, Dec. 12-15, 1983, Washington, D.C., pp. 285-290. ................................... 
Cody, R.D., and A.B. Hull (1980), Experimental Growth of Primary Anhydrite at Low Temperatures and Water Salinities, Geology, 8:505-509

Conradt, R., H. Engelke, and A. Kaiser (1982), Investigations of the Solution Behavior of $\mathrm{VaCl}$ in the Quinary System $\mathrm{NaCl}-\mathrm{KCl}-\mathrm{MgCl}_{2}-\mathrm{MgSO}_{4}-\mathrm{H}_{2} \mathrm{O}$ at Different Temperatures, in Scientific Basis for Nuclear Waste Management V, W. Lutze, ed., Elsevier, New York, pp. 487-490 .

Coons, W.E., D. Meyer, R.L. Olsen, and J.K. Register (1984), The Geochemistry of the Castile Brines: Implications for their Origin and Impact on the WIPP Site, in Scientific Basis for Nuclear Waste Management VII, G.L. McVay, ed., Elsevier, New York, pp. 49-58 ...................

Elders, W.A., and L.H. Cohen (1983), The Salton Sea Geothermal Field, California, as a Near-Field Natural Analog of a Radioactive Waste Repesitory in Salt, prepared for Office of Nuclear Waste Isolation Report BMI/ONWI-513, Battelle Memorial Institute, Columbus, Ohio, 155 pp.

Elders, W.A., and J.B. Moody (1985), The Salton Sea Geothermal Field as a Natural Analog for the Near-Field in a High-Level Nuclear Waste Repository, in Scientific Basis for Nuclear Waste Management VIII, C.M. Jantzen et al., eds., Moterials Research Society, Pittsburgh,

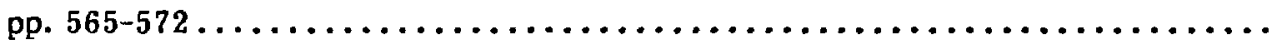

Eugster, H.P., and B.F. Jones (1979), Behavior of Major Solutes during ClosedBasin Brine Evolution, American Journal of Seience, 279:609-631 . . . . . . .

Gnirk, P.S., W.B. Krause, and A.S. Fossura (1981), State-of-the-Art Review of Brine Migration Studies in Salt, Sandia National Laboratories Technical Memorandum Report RSI-0075, SAND-81-7054, 52 pp. . . . . . . . . . . .

Gray, W.J. (1984), Gamma Radiolysis of Groundwater Found near Potential Radioactive Waste Repositories, Nuclear Waste Management, G.G. Wicks and W.A. Ross, eds., American Ceramic Society Report CONF-830451, pp. $57-61 \ldots \ldots \ldots \ldots \ldots \ldots \ldots \ldots \ldots \ldots \ldots \ldots \ldots \ldots \ldots \ldots \ldots \ldots \ldots \ldots \ldots$

Gray, W.J., and S.A. Simonson (1985), Gamma and Alpha Radiolysis of Salt Brines, in Scientific Basis for Nuclear Waste Management VIII, C.M. Jantzen et al., eds., Materials Research Society, Pittsburgh, pp. 623-630.........................................

Hansen, F.D. (1984), Physical and Mechanical Variability of Natural Rock Salt, Proc. Second Conf. on the Mechanical Behavior of Salt, Trans Tech Publications, Clausthal-Zellerfeld, West Germany, in press, 17 pp. 
Hardie, L.A. (1984), Evaporites: Marine or Non-Marine?, American Journal of Science, 284:193-240

Harvie, C.E., H.P. Eugster, and J.H. Weare (1982), Mineral Equilibria in the Six-Component Seawater System, $\mathrm{Na}-\mathrm{K}-\mathrm{Mg}-\mathrm{Ca}-\mathrm{SO}_{4}-\mathrm{Cl}-\mathrm{H}_{2} \mathrm{O}$ at $25^{\circ} \mathrm{C}$ : II. Compositions of the Saturated Solutions, Geochemica et Cosmochimica Acta, 46:1603-1618.

Harvie, C.E., N. Moller, and J.H. Weare (1984), The Prediction of Mineral Solubilities in Natural Waters: The Na-K-Mg-Ca-H-Cl-SO${ }_{4}^{-O H}-\mathrm{HCO}_{3}-$ $\mathrm{CO}_{3}-\mathrm{CO}_{2}-\mathrm{H}_{2} \mathrm{O}$ System to High Ionic Strengths at $25^{\circ} \mathrm{C}$, Geochemica et Cosmochimica Acta, 48:723-751

Helgeson, H.C. (1969), Thermodynamics of Hydrothermal Systems at Elevated Temperatures and Pressures, American Journal of Science, 267:

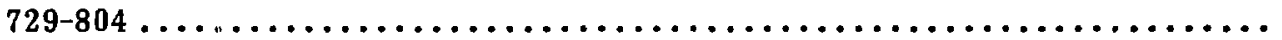

Hull, A.B., and M.G. Seitz (1985), An Integrated Approach to Determining Site Specific Brine Migration Parameters, Proc. U.S. Department of Energy Salt Repository Project Workshop on Brine Migration, Berkeley, Calif.,

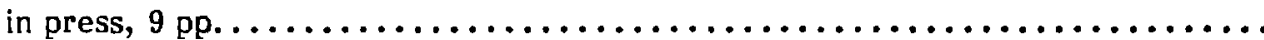

Isherwood, D.J. (1979), Fluid Inclusions in Salt - An Annotated Bibliography, Lawrence Livermore National Laboratory Report UCID-18102, 29 pp. .......

Jackson, D.D. (1984), PROTOCOL, A Numerical Simulator for the Dissolution of Inorganic Solids in Aqueous Solutions, Lawrence Livermore National

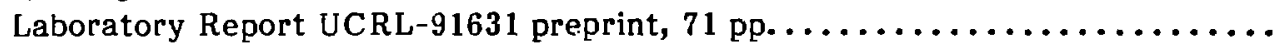

Jain, U., and A.B. Lidiard (1977), The Growth of Colloidal Centers in Irradiated Alkali Halides, Philosophical Magazine, 35:245-259

Jenks, G.H. (1972), Radiolysis and Hydrolysis in Salt-Mine-Brines, Oak Ridge National Laboratory Report ORNL-TM-3717, 99 pp.................

Jenks, G.H. (1979), Effects of Temperature, Temperature Gradients, Stress, and Irradiation on Migration of Brine Inclusions in a Sait Repository, Oak Ridge National Laboratory Report ORNL-5526, 67 pp..............

Jenks, G.H., and H.C. Claiborne (1981), Brine Migration in Salt and Its Implications in the Geologic Disposal of Nuclear Waste, Oak Ridge National Laboratory Report ORNL-5818, 164 pp....................

Jenks, G.H., E. Sonder, C.D. Bopp, J.R. Walton, and S. Lindenbaum (1975), Reaction Products and Stored Energy Released from Irradiated Sodium Chloride by Dissolution and by Heating, Journal of Physical Chemistry, 79:871-875 
Jockwer, N. (1984), Laboratory Investigations on Radiolysis Effects on Rock Salt with Regard to the Disposal of High-Level Radioactive Wastes, in Scientific Basis for Nuclear Waste Management VII, G.L. McVay, ed., Elsevier, New York, pp. 17-25 ..............................

Kauf mann, D.W., ed. (1960), Sodium Chloride: The Production and Properties of Salt and Brine, American Chemical Society Monograph Series No. 145,

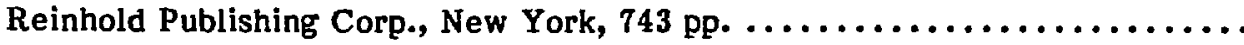

Kerrisk, J.F. (1985), Solubility Limits on Radionuclide Dissolution, in Scientific Basis for Nuclear Waste Management VIII, C.M. Jantzen et al., eds., Materials Research Society, Pittsburgh, pp. 237-244 ...............

Krause, W.B. (1983), Avery Island Brine Migration Tests: Installation, Operation, Data Collection, Analysis, Office of Nuclear Waste Isolation Report ONWI-190(4), Battelle Memorial Institute, Columbus, Ohio, $91 \mathrm{pp}$.

Lambert, S.J. (1980), Mineralogical Aspects of Fluid Migration in the Salt Block II Experiment, Sandia National Laboratories Report SAND 79-2423,

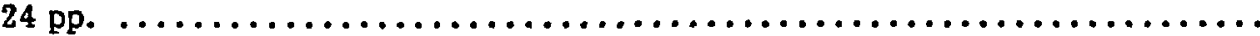

Lerman, A. (1970), Chemical Equilibria and Evolution of Chloride Brine, Mineral Society of America Special Paper 3, pp. 291-306

Lerman, A. (1979), Geochemical Processes, Wiley-Interseience, New York,

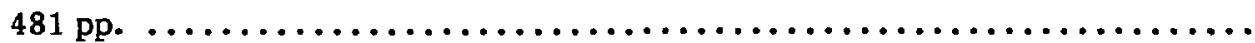

Levy, P.W. (1983), Radiation Damage Studies on Natural Rock Salt from Various Geological Localities of Interest to the Radioactive Waste Disposal Program, Nuclear Technology, 60:231-243

Levy, P.W., J.M. Loman, and J.A. Kierstead (1984), Radiation Induced F-Center and Colloid Formation in Synthetic $\mathrm{NaCl}$ and Natural Rock Salt: Applications to Radioactive Waste Repositories, Nuclear Instruments and Methods in Physics Research, B1:549-556

Lindstrom Jensen, K.E. (1982), Dissolution Rate of Salt Domes on the Basis of Interpretation of Measured Salinity Profiles, in Scientific Basis for Nuclear Waste Management V, W. Lutze, ed., Elsevier, New York, pp. 429-438.

Loman, J.M., P.W. Levy, and K.J. Swyler (1982), Radiation-Induced Sodium Metal Colloid Formation in Natural Rock Salt from Different Geological Localities, in Seientific Basis for Nuclear Waste Management VI, S.V. Topp, ed., Elsevier, New York, pp. $433-440 \ldots \ldots \ldots \ldots \ldots \ldots \ldots \ldots \ldots$ 
Markham, J.J. (1966), F-Centers in Alkali Halides, Academic Press, New York,

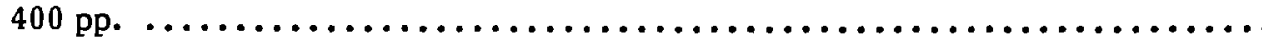

Marshall, W.L., and R. Slusher (1966), Thermodynamics of Calcium Sulfate Dihydrate in Aqueous Sodium Chloride Solutions, $0-110^{\circ}$, Journal of

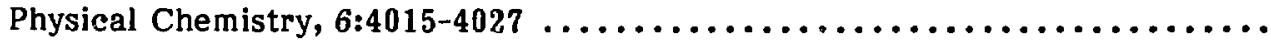

Melchior, D.C. (1984), The Application of Ion-Interaction Theory of Electrolytes to the Solubilities of Copper and of Some Alkaline-Earth Sulfates in Brine, Ph.D. dissertation, Colorado School of Mines, Golden, Colo., 91 pp. ....................................

Melchior, D., D. Langmuir, P.S.Z. Rogers, and N. Hubbard (1985), The Thermodynamics and Geochemistry of $\mathrm{Ca}, \mathrm{Sr}, \mathrm{Ba}$, and Ra Sulfates in Some Deep Brines from the Palo Duro Basin, Texas, in Scientific Basis for Nuclear Waste Management VIII, C.M. Jantzen et al. eds., Materials Research Society, Pittsburgh, pp. 483-489

Molecke, M.A. (1982), A Comparison of Brines Relevant to Nuclear Waste Experimentation, Sandia National Laboratories Report SAND 83-0516,

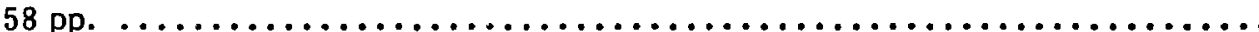

Moody, J.B. (1982), Radionuclide Migration/Retardation Research and Development - Technology Status Report, Office of Nuclear Waste Isolation Report ONWI-321, Battelle Memorial Institute, Columbus,

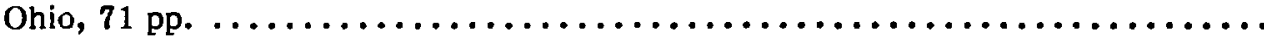

Myers, J., G. Ulmer, D. Grandstaff, R. Brozdowski, M. Danielson, and O. Koski (1984), Development in the Monitoring and Control of Eh and $\mathrm{pH}$ Conditions in Hydrothermal Experiments, in Geochemical Behavior of Disposed Radioactive Wastes, G. Barney et al., eds., ACS Symposium Series 246, American Chemical Society, Washington, D.C.,

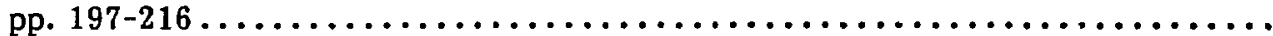

Olander, D.R. (1984), A Study of Thermal-Gradient-Induced Migration of Brine Inclusions in Salt: Final Report, Office of Nuclear Waste Isolation Report BMI/ONWI-538, Battelle Memorial Institute, Columbus, Ohio,

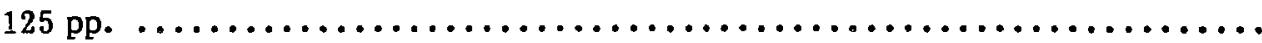

Olander, D.R., A.J. Machiels, and E. Muchowski (1981), Migration of Gas-Liquid Inclusions in Single Crystals of Potassium and Sodium Chlorides, Nuclear Science and Engineering, 79:212-227

Panel on the Waste Isolation Pilot Plant (1984), Review of the Scientific and Technical Criteria for the Waste Isolation Pilot Plant (WIPP), Board on Radioactive Waste Management, Commission on Physicel Sciences, Mathematics, and Resources, National Research Council, National Academy Press, Washington, D.C., 130 pp. ...................... 
Panno, S.V., and P. Soo (1984), Potential Effects of Gamma Irradiation on the Chemistry and Alkalinity of Brine in High-Level Nuclear Waste Repositories in Rock Salt, Nuclear Technology, 67:268-281 .............

Patil, S.F., D. Ravishankar, P. Bhatie, and I.B. Chowdhary (1984), Chemical Effects Induced by Gamma-Irradiated Salts in Aqueous Medium, International Journal of Applied Radiation and Isotopes, 35:459-462

Pederson, L.R. (1985), Chemical Implications of Heat and Radiation Damage to Rock Salt, in Scientific Basis for Nuclear Waste Management VIII, C.M. Jantzen et al., eds., Materials Research Society, Pittsburgh, pp. 701-708

Pederson, L.R., D.E. Clark, F.N. Hodges, G.L. MeVay, and D. Rai (1984), The Expected Environment for Waste Packages in a Salt Repository, in Scientific Basis for Nuclear Waste Management VII, G.L. McVay, ed., Elsevier, New York, pp. 417-426 ............................

Pigford, T.H. (1982), Migration of Brine Inclusions in Salt, Nuclear Technology, 56:93-101

Potter, R.W., II, and M.A. Clynne (1978), Solubility of Highly Soluble Salts in Aqueous Media - Part $1, \mathrm{NaCl}, \mathrm{KCl}, \mathrm{CaCl} 2, \mathrm{Na}_{2} \mathrm{SO}_{4}$, and $\mathrm{K}_{2} \mathrm{SO}_{4}$ Solubilities to $100^{\circ} \mathrm{C}$, Journal of Research of the U.S. Geological Survey, 6(6):701-705

Ratigan, J.L. (1984), A Sensitivity Study of Brine Transport into a Borehole Containing a Commercial High-Level Waste Canister, Nuclear Technology, 67:228-244

Roedder, E. (1984), Fluid Inclusions, Reviews of Mineralogy, Vol. 12, Mineralogical Society of America, Washington, D.C., 644 pp..............

Roedder, E. (1984), The Fluids in Salt, American Mineralogi ‘, 69: 413-439

Roedder, E., and R.L. Bassett (1981), Problems in Determination of the Water Content of Rock-Salt Samples and Its Significance in Nuclear-Waste

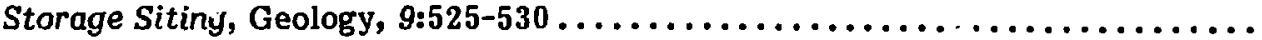

Roedder, E., and I.M. Chou (1982), A Critique of "Brine Migration in Salt and Its Implications in the Geologic Disposal of Nuclear Waste," Oak Ridge National Labciatory Report 5818 by G.H. Jenks and H.C. Claiborne, U.S. Geological Survey Open-File Report 82-1131, 31 pp. ..............

Rogers, P.S.Z. (1981), Thermodynamics of Geothermal Fluids. Ph.D. dissertation, University of California, Berkeley, 243 pp. ............... 
Shade, J.W. (1985), Current Generic Issues Related to Near-Field Materials

Testing, in Scientific Basis for Nuclear Waste Management VIII, C.M.

Jantzen et al., eds., Materials Research Society, Pittsburgh,

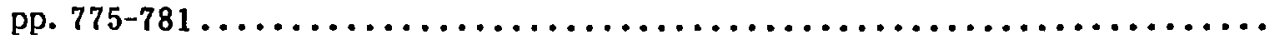

Shefelbine, H.C. (1982), Brine Migration: A Summary Report, Sandia

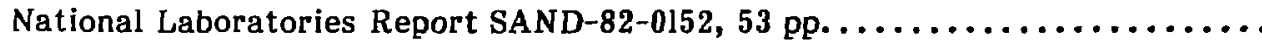

Silva, R.J., and H. Nitsche (1984), Thermodynamic Properties of Chemical

Species of Waste Radionuclides, in Proc. Nuclear Waste Geochemistry '83,

D.H. Alexander and G.F. Birchard, eds., U.S. Nuclear Regulatory

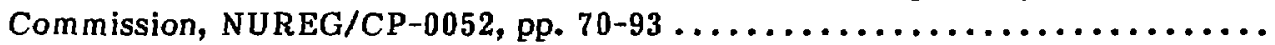

Silvester, L.F., and K.S. Pitzer (1977), Thermodynamics of Electrolytes:

8. High-Temperature Properties, Including Enthalpy and Heat Capacity,

with Application to Sodium Chloride, Journal of Physical Chemistry,

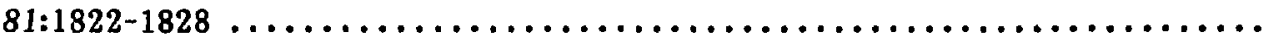

Sìmonson, S.A., and W.L. Kuhn (1984), Predicting Amounts of Radiolytically Produced Species in Brine Solutions, in Scientific Basis for Nuclear Waste Management VII, G.L. McVay, ed., Elsevier, New York, pp. 17-25 ..........

Sonnenfeld, P. (1984), Brines and Evaporites, Academic Press, Orlando, Fla.,

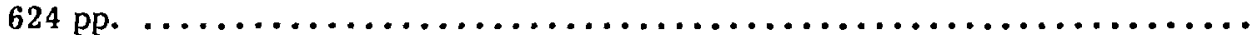

Sonnenfeld, P., and P.P. Hudec (1985), Origin of Clay Films in Rock Salt,

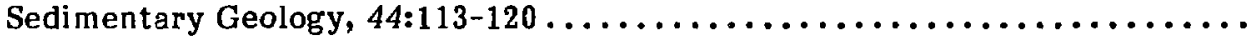

Stewart, D.B., and R.W. Potter, II, (1979), Application of Physical Chemistry of Fluids in Rock Salt at Elevated Temperatures and Pressure to Repositories for Radioactive Waste, in Scientific Basis for Nuclear Waste Management I, Plenum Press, New York, pp. 297-311 ............

Uerpmann, P., and N. Jockwer (1982), Salt as a Host Rock for Radioactive Waste Disposal, in Geological Disposal of Radioactive Waste: Geochemical Processes, Organization for Economic Cooperation and Development, Nuclear Energy Agency, Paris, pp. 93-103 ...............

Van den Broek, W. (1982), Impurities in Rock-Salt: Consequences for the Temperature Increases at the Disposal of High-Level Nuclear Waste, National Technical Information Service, NTIS BP83-102087, 51 pp. .........

Weber, W.J., L.R. Pederson, W.J. Gray, and G.L. MeVay (1984), Radiation Effects on Nuclear Waste Storage Materials, Nuclear Instruments and Methods in Physies Research, B1:527-533 
Westinghouse Electric Company (1983), Brine Migration Test for Asse Mine, Federal Republic of Germany, Final Test Plan, Office of Nuclear Waste Isolation Report ONWI-242, Battelle Memorial Institute, Columbus, Ohio, 239 pp. .............................................

Wilgus, C.K., and W.T. Holser (1984), Marine and Nonmarine Salts of Western Interior, United States, American Association of Petroleum Geologists Bulletin, 68:765-767 ....................................

Wolery, T.J., D.J. Isherwood, K.J. Jackson, J.M. Delany, and I. Puigdomenech (1984), EQ3/6: Status and Applications, Proc. Conf. on the Application of Geochemical Models to High-Level Nuclear Waste Repository Assessment, G.K. Jacobs and S.K. Whatley, eds., Oak Ridge National Laboratory

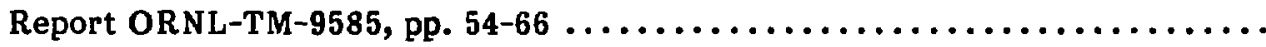

Wollenberg, H., D. Brookins, L. Cohen, S. Flexser, M. Abashian, M. Murphy, and A. Williams (1984), Uranium, Thorium, and Trace Elements in Geologic Occurrences as Analogues of Nuclear Waste Repository Conditions, Proc. Nuclear Waste Geochemistry '83, D.H. Alexander and G.F. Birchard, eds., U.S. Nuclear Regulatory Commission Report NUREG/CP-0052, pp. $464-491$.

Wood, S.A., D.A. Crerar, S.L. Brantley, and M. Boresik (1984), Mean Molal Stoichiometric Activity Coefficients of Alkali Halides and Related Electrolytes in Hydrothermal Solutions, American Journal of Science, 284:668-705 ...........................................

Yagnik, S.L. (1983), Thermal-Gradient Migration of Brine Inclusions in Salt Crystals, unpublished Ph.D. dissertation, Lawrence Berkeley National

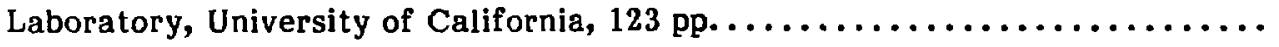

Zand, S.M. (1982), Dissolution of Evaporites and Its Possible Impact on the Integrity of the Waste Isolation Pilot Plant (WIPP), New Mexico, USA, in Scientific Basis for Nuclear Waste Management V, W. Lutze, ed., Elsevier, New York, pp. 439-448............................. 


\section{SUBJECT INDEX}

Abstracts, 10

Activity coefficients, 18, 20, 21

Alkaline-earth sulfates, 6, 19, 52

Alliance Basin, 6

Alpha radiation, 23, 24, 52

Americium, 48, 49

Analytical methods

brine formulations, 12,13

chlorine determination, 23, 28

petrographic, 39

solubility determination, 16, 20

stored energy, 25

water content in salt, 13

Anhydrite, 6, 8, 10, 11, 19, 26, 54, 57, 58

Asse mine, 26, 45

Avery Island salt, 7, 39

Bedded salt, 3, 37, 57

Bibliography, 10

Bitterns, 14

Borehole, 43

Brine

at waste package, 52

chemistry, $11,12,14,15,30,32,52,54$

complex, 20

corrosion, 56

deep, 11

evolution, 5

inclusions (see also under Fluid

inclusion), 12, 13, 33

inflow, 43, 45

migration (see also under Migration of brine), 24, 35, 36

migration rate, 43

mixing, 10, 15

origin, $\mathbf{5 9}$

$\mathrm{pH}, 11,30$

purification, 4
Brine (Cont'd)

radiolysis, $23,30,32,52$

transport, 41,43

Brittle salt, 29

Canister, high-level waste, 43

Cap rock, 9, 56

Carnallite, $8,40,56,58$

Castile brines, 59

Chemical fractionation, 5

Chemical impurities, 7

Chlorides (see also Rock salt; Salt;

Sodium chloride)

potassium, 40

sodium, 40

Clay, $8,11,44,58$

Colloid sodium formation (see also under Gamma radiation), 26-29

Computer codes

$\mathrm{EQ} 3 / 6,17,37,47$

MAKSIMA-CHEMIST, 24

MIGRAIN, 38

MINEQL, 17, 49

PROTOCOL, 16, 17

RADIOL, 31, 37

Computer model (see also Computer codes), 20, 43

Core samples, 37

Corrosion, $30,32,45,56$

Creep deformation, 7 rates, $\mathbf{5 9}$

Crystals, 6, 40

Deaquation, 10 
Deep dissolution, 60

Deformation-dissolution, $\mathbf{5 7}$

Delaware Basin, 6, 39, 50, 57-60

Diffusion coefficients, $4,33,43$

F-center, 24

ion, 4,34

of water in salt, 46,58

thermal, 4, 33, 43

Dike geochemistry, 50

Dissolution rates, 9

Domal salt, 3,9

Electrolyte thermodynamics, 19-21

Equilibrium gas pressures, 23, 24

\section{Evaporites}

dissolution, 10, 60

formation, $3,5,6,15$

impurities, 8, 56

mineralogy, 3, 6, 45, 54, 58

primary, 5, 6

postdepositional alteration, 4, 5

radiolysis, 26,27

Exchange reactions, 5

F-center formation, 24, 27-29

Fluid inclusion

bibliography, 10

bi-phase, $35,39,40,46$

chemical characteristics, 12

intercrystalline, $12,13,44$

intracrystalline, $12,13,44$

morphology, 12, 15, 38

Fluid migration (see also Migration of brines), 35

Gamma radiation

chemical effect, $25,26,31,32,52,54$

in brines, 24, 25

modification, 54

near-field effect, 55

on salt, 24,26

pH effects, 30
G-values, 25

Geochemical modeling equilibria in high ionic strength solutions, $11,14,15,19$

hydrothermal systems, 18 leaching of inorganic solids, 16 radiolysis, 32

systems approach, 37,48

Geothermal fluids, $16,20,47,53$

Gibson Dome, 52

Glass waste form, 12,23

Gradient migration, 25, 33, 40, 46

Gypsum, 6, 10, 11, 18, 19, 26, 45, 54

Heat capacity, 18, 20, 21

Heater borehole test, 38

High-level waste disposal in salt, 55

Hydrothermal systems, 16, 18, 21

Hydrous minerals, 6, 8, 13, 26, 58

In situ tests (see also Migration of brine), 37

Ion-interaction theory, $15,19,20$

Kainite, 8, 56

Kieserite, 8, 26, 56

Kinetics

dissolution of inorganic solids, 16

formation of secondary reaction products, 53

interfacial control of brine migration, $33,34,40,41,46$

leachi.ug of glass, 23

of radiolytically produced species, 32

salt dissolution, $\mathbf{g}$

sodium colloid formation, $27, \mathbf{2 9}$

Liquid inclusions (see also Fluid inclusions), 40, 46 
Liquid migration (see also Migration of brine), 45

Marine salts deposits, 5

origin, 6

solubilities, 56

McNutt evaporite, 30, 57

Microfractures, 35

Migration of brine

bi-phase, 35, 40

experiments, 33

flow rates, $33-46,48$

grain-boundary effects, $33,37,42,44$

inclusions, 33, 40, 41

in situ tests, 37,38

interfacial kinetics, 33, 34, 40, 46

mechanisms, 33,45

single-phase, 35,40

review, $35,38,52$

Mississippi Chemical Corporation mine, 44

Modeling studies (see also Geochemical modeling), 37

Mors Salt Dome, 9

Multibarrier system, 48

Neodymium, 49

Nuclear repository

environmental conditions, 54

government guidelines, 3

natural analog, $47,48,53$

predicted waste package environment, 51-60

selection criteria, $\mathbf{5 9}$

site, 11, 12, 51-60

test brines, 12, 43

Organic compounds crystallization modification, 6 radionuclide complexation, 48

Osmotic coefficients, 18, 20, 21

Palo Duro Basin salt, 7, 11, 31

Paradox Basin salt, 31
Permeability, 37, 51, 56

Permian Basin brine, 12, 24, 54, 59

Pitzer equations, 15, 18-21

Polyhalite, 8, 26, 39, 45, 56, 58

Precipitation, 34

Pressure effects, 18, 21, 23, 51, 59

Project Salt Vault, 37

Radiation (see also Alpha radiation;

Gamma radiation) dose effects, 27,29 experimentation, 26

fields, 52 induced colloid formation, 24, 27, 28 natural sources, 3

Radioactive intrusive rocks, 49

Radiolysis (see also Alpha radiation;

Gamma radiation; Radiation), 23-38, 52

Radionuclide

complexation, 48,49

dissolution, 47

migration, 11,48

mobility, $19,47,49$

solubility, 48,49

sorption, 56

speciation, 49

Repository (see also Nuclear repository), 12,37

Richton Dome, 40

Rock salt (see also under Evaporites; Salt) as brine chemistry pointer, 37 decrepitation, 3 deformation, 7 impurities, 7,8 irradiation, 25-29, 31, 54 thermal effects, 27,31 water content, $3,13,14$

Sabkha, 5, 6, 15

Salado Formation, 6, 30, 38, 42, 57-60 
Salina Basin salt, 7

Salinity profiles, 9

Salt

beddeã, 8,13

consolidation, 51

crystalline parameters, $\mathbf{3 5}$

dissolution, 9,34

domes, 9, 13

economics, 4

fluid inclusions, $10,13,35,38,41,44$

fluid migration, $10,33-46$

fluid release rates, 37

irradiation, 24-29, 54

microstructure, $\mathbf{3 3}$

nonmarine, 6

origin, 3

polycrystalline, 33,45

processing, 4

properties, 4

repository, $35,51-60$

solubility, 16,37

synthetic, 31, 33, 40

uses, 4

\section{Salton Sea}

brines, 53

geothermal field, 47,53

Saturation

limiting dissolution, 47

salt solutions, 15

Sediment-brine reactions, 10

Shallow dissolution, 60

Sodium

colloid formation, 29

metal, 29

Sodium chloride (see also Rock salt; Salt) gamma irradiation, 24

review, 4

saturation, 15

Solubility

models, $10,11,15-17$

experimental determinations, 16, 54

effect of stress, 37

products, 18, 19

radionuclide, 47,48
Sorption, 5, 48

Soret coefficients (see also Diffusion, thermal), 4, 33, 44

Speciation, 48

Stored eriergy, 25

Strain effects, 27

Stress

applied, 7, 37, 38

gradient transport, 45

Temperature effects on

brine composition, 12, 14, 15

brine migration, 45

consolidation, 51

salt decrepitation, $3,25,31$

sodium colloid formation, $24,27,30$

solubility determinations, $16,18,20$

Thermal (see also Temperature effects) annealing, 25, 30, 32

conductivity, 8

effects, 27, 31

gradient migration, $25,33,40,46$

Thermochemical equilibrium, 16

Thermodynamic

modeling, 15, 16, 18, 59

properties, $11,20,21,49$

Thorium, 49

Trace element mobilization, 19, 47, 49

Transition salt, 45

Triaxial compression tests, 7

Tritiated brine tracer, 57

Uranium, 47, 49

Vapor

liquid inclusions, $35,41,46$

phase transport, 45

pressure method for determining activity coefficients, $\mathbf{2} 1$ 
Waste

disposal site, 12

form, $23,40,53$

package, 52

Water

groundwater, 11,57

marine vs. nonmarine sources, $5,6,8$ pore fluid, 6

rock salt content, $13,37,39,44$
Water (Cont'd)

sulinities, 6

seawater, $5,12,15$

sources in rock salt, $3,13,37,59$

Williston Basin, 6

WIPP, $6,12,38,57-60$

Yueca Mountain, 47 